\title{
Cationic Substitutions in Hydroxyapatite: Current Status of the Derived Biofunctional Effects and Their In Vitro Interrogation Methods
}

\author{
Teddy Tite ${ }^{1}$, Adrian-Claudiu Popa ${ }^{1,2}$, Liliana Marinela Balescu ${ }^{1}$, Iuliana Maria Bogdan ${ }^{1}$,
} Iuliana Pasuk ${ }^{1}\left(\mathbb{D}\right.$, José M. F. Ferreira ${ }^{3, *}$ ) and George E. Stan ${ }^{1, *}$

1 National Institute of Materials Physics, RO-077125 Magurele, Romania; teddy.tite@infim.ro (T.T.); adrian.claudiu@gmail.com (A.-C.P.); liliana.trinca@infim.ro (L.M.B.); iuliana.bogdan@infim.ro (I.M.B.); iuliana.pasuk@infim.ro (I.P.)

2 Army Centre for Medical Research, RO-010195 Bucharest, Romania

3 Department of Materials and Ceramics Engineering, CICECO, University of Aveiro, 3810-193 Aveiro, Portugal

* Correspondence: jmf@ua.pt (J.M.F.F.); george_stan@infim.ro (G.E.S.); Tel.: +351-234-370242 (J.M.F.F.); +40-724-131131 (G.E.S.); Fax: +351-234-370204 (J.M.F.F.); +40-21-3690177 (G.E.S.)

Received: 17 September 2018; Accepted: 19 October 2018; Published: 24 October 2018

check for updates

\begin{abstract}
High-performance bioceramics are required for preventing failure and prolonging the life-time of bone grafting scaffolds and osseous implants. The proper identification and development of materials with extended functionalities addressing socio-economic needs and health problems constitute important and critical steps at the heart of clinical research. Recent findings in the realm of ion-substituted hydroxyapatite (HA) could pave the road towards significant developments in biomedicine, with an emphasis on a new generation of orthopaedic and dentistry applications, since such bioceramics are able to mimic the structural, compositional and mechanical properties of the bone mineral phase. In fact, the fascinating ability of the HA crystalline lattice to allow for the substitution of calcium ions with a plethora of cationic species has been widely explored in the recent period, with consequent modifications of its physical and chemical features, as well as its functional mechanical and in vitro and in vivo biological performance. A comprehensive inventory of the progresses achieved so far is both opportune and of paramount importance, in order to not only gather and summarize information, but to also allow fellow researchers to compare with ease and filter the best solutions for the cation substitution of HA-based materials and enable the development of multi-functional biomedical designs. The review surveys preparation and synthesis methods, pinpoints all the explored cation dopants, and discloses the full application range of substituted HA. Special attention is dedicated to the antimicrobial efficiency spectrum and cytotoxic trade-off concentration values for various cell lines, highlighting new prophylactic routes for the prevention of implant failure. Importantly, the current in vitro biological tests (widely employed to unveil the biological performance of HA-based materials), and their ability to mimic the in vivo biological interactions, are also critically assessed. Future perspectives are discussed, and a series of recommendations are underlined.
\end{abstract}

Keywords: biomedicine; hydroxyapatite; cation substitution; co-doping; biological assays

\section{Introduction}

Over the last decades, the biomedical orthopaedic and dentistry sectors have witnessed an unprecedented demand for a large variety and number of scaffolds, grafts, implants, and endo- 
prostheses. The increase in life expectancy, and the higher frequency of injuries and diseases are regarded as the main factors for this growing demand in orthopaedic and dental devices. The quality of life for millions of people has been drastically improved by using hydroxyapatite (HA) and bioactive glasses (BGs) for bone repair and tissue regeneration [1-19]. In particular, synthetic stoichiometric hydroxyapatite (having the $\mathrm{Ca}_{10}\left(\mathrm{PO}_{4}\right)_{6}(\mathrm{OH})_{2}$ stoichiometry and theoretical $\mathrm{Ca} / \mathrm{P}$ molar ratio of 1.67), calcium-deficient hydroxyapatite, or oxyapatite have been widely used as prominent bioactive materials in healthcare due to their excellent biocompatibility, non-toxicity and osteoconductive properties [1,2,20-22]. This was an obvious choice, since these materials are inspired by nature, HA being the major mineral component of hard conjunctive tissues (e.g., bone and teeth). Moreover, $\mathrm{HA}$ is able to accommodate healthy osteoblast (bone growth cells) and osteoclast (bone resorption cells) adhesion and growth, as well as to promote stem cell proliferation and differentiation [1,2,23-26]. However, synthetic HA has poor mechanical properties (e.g., poor tensile strength and low fracture toughness), and cannot be used for the fabrication of mechanically safe load-bearing bulk implants or prostheses. Thereby, HA use is limited to porous scaffolds as bone grafts or fillers [27-31] and coatings for the bio-functionalization of metallic implants [1,2,23,32-39].

Studies concerning the electrical properties of HA occupy a special place in the research topic of biomaterials. The discovery of the piezoelectric effect in dry bone by Fukada and Yasuda in 1957 [40] seemed to offer an explanation to certain observed phenomena, such as bone remodelling as the effect of electric charge accumulation on the surface of crystallites due to mechanical stress. Fast bone fracture healing was observed when mechanical loading was applied [41,42]. The process of mechano-transduction was advanced as a possible cause for osteogenesis [41]. It is believed that the electrical dipoles generated by the action of mechanical stress on the bone matrix (collagen and hydroxyapatite exhibiting piezoelectric properties) could increase the interaction with the cells pointing them in the direction of "force lines" (for the production of 3D tracts with a 3D disposition that supports maximum mechanical stress) and could attract calcium and phosphate ions, leading to the acceleration of mineralization, regeneration and bone growth processes. Also, the mechanical stress activates specific adaptive responses in osteoblasts and osteoclast cells, their cytoskeleton being connected to the bone matrix through cell-matrix junctions. The actin cytoskeleton receives mechanical stress stimuli from the focal adhesion type of junction, which will activate the YAP (yes-associated protein 1) transcription co-activator and TEAD (transcriptional enhanced associate domain) transcription factor (through Hippo signalling pathway). This increases transduction of genes related to proliferation or differentiation (e.g., c-fos, egr-1, iex-1, c-myc) [43]. The protein p130Cas, a component of the focal adhesion junction acts also as a mechanical transduction molecule, leading to Rac activation. Another mechanism of cytoskeleton modulation of cellular function is performed through Rho-family GTPases. The microtubule and intermediate filaments of the cytoskeleton respond to mechanical stimuli by spatial migration and cell division direction in the tissue [43].

However, HA seemingly crystallizes in hexagonal symmetry, space group $\mathrm{P} 6_{3} / \mathrm{m}$, with an inversion centre, which does not allow the piezoelectric effect to occur. In the HA crystal lattice, the $\left(\mathrm{PO}_{4}\right)^{3-}$ tetrahedrons are joined together by $\mathrm{Ca}^{2+}$ bridges. The space between $\left(\mathrm{PO}_{4}\right)^{3-}$ groups is relatively large allowing the accommodation of foreign atoms with quite different diameters from $\mathrm{Ca}^{2+}$. The $(\mathrm{OH})^{-}$ions are aligned along the six-fold axis of the lattice, bounded by columns of $\mathrm{Ca}^{2+}$ and $\left(\mathrm{PO}_{4}\right)^{3-}$ forming the so-called "apatitic channel". Since the $(\mathrm{OH})^{-}$ions appear to play an important role in ionic conduction [44,45], a HA crystallite can be regarded as a one-dimensional anionic conductor along the $c$-axis $[44,46]$.

Given the non-polar crystal structure of HA, Fukada and Yasuda [40] attributed the observed piezoelectric effect to collagen, a protein of quasi-ordered, polar structure, which definitely has piezoelectric behaviour. Although most researchers in the field agree that the responsibility for the clearly proven piezoelectricity of dry bones is the collagen structure, there are still groups that associate (at least partially) the phenomenon to the intrinsic structure of mineral HA. A possible alternative explanation would be that HA nanocrystals actually have a monoclinic, polar structure-space group 
$\mathrm{P} 2_{1} / \mathrm{b}$ [47-49]. Since the monoclinic deformation is weak, the HA-monoclinic structure cannot be practically distinguished from the hexagonal one by powder diffractometry. Lang et al. [47-49] have obtained clear evidence of piezo-, pyro- [48] and even ferro-electric [49] behaviour of synthetic HA films (having a (001) preferential orientation of the 70-100 $\mathrm{nm}$ large crystallites) deposited by sol-gel on silicon substrate. The piezoelectric effect was also measured in HA ceramics sintered by spark plasma sintering [47]. Furthermore, Lang et al. stressed that not all HA particles give the equally strong piezoelectric signal, which is why the macroscopic effect is not conclusive [49].

The continuous effervescence of the ever-topical HA research field is demonstrated by a progressive yearly increase of published papers (Figure 1), since 2009 constantly exceeding more than 1000 items per year. To date more than 21,000 HA papers were published.

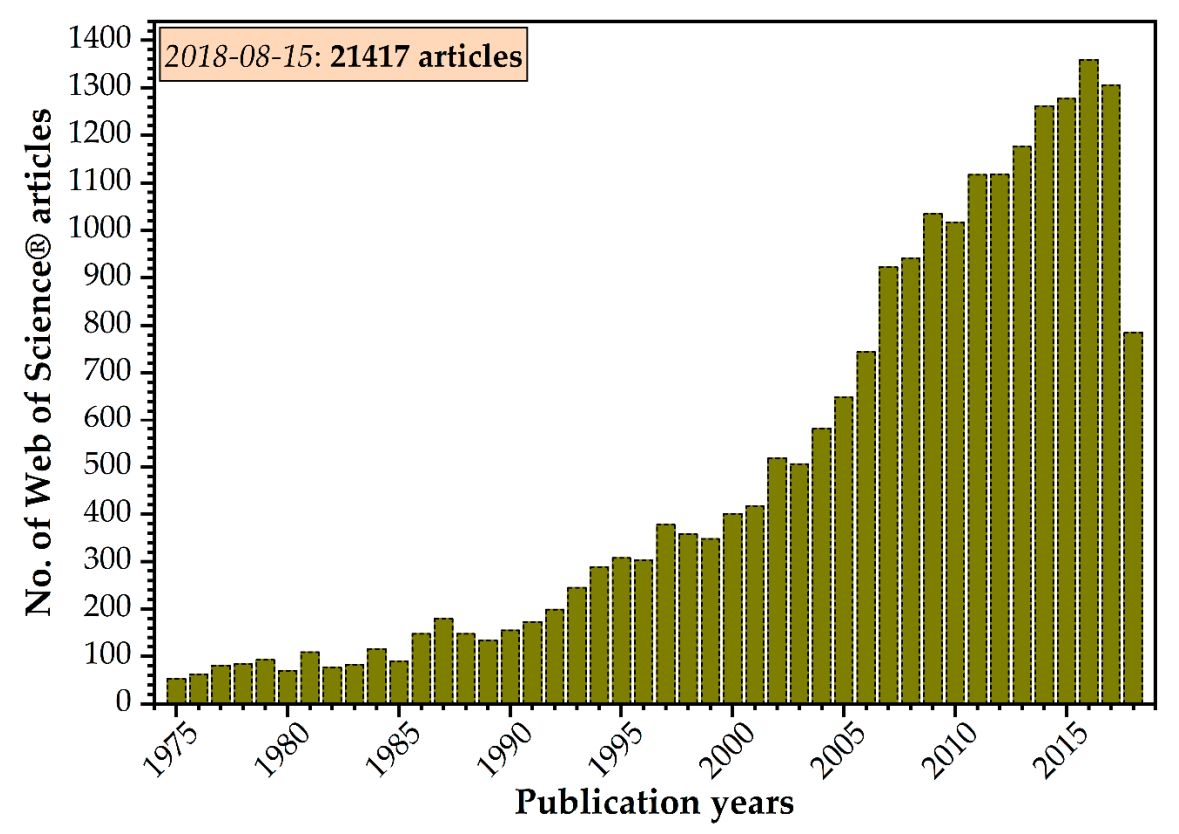

Figure 1. Yearly distribution of scientific articles published on the hydroxyapatite topic over the 1975-2018 period (15th of August 2018). Database: Clarivate Analytics-Web of Science ${ }^{\circledR}$ Core Collection. Coupled «title» and «topic» search keywords: "hydroxyapatite", "hydroxylapatite", "HA", "HAp", " $\mathrm{Ca}_{10}\left(\mathrm{PO}_{4}\right)_{6}(\mathrm{OH})_{2}$, and " $\mathrm{Ca}_{5}\left(\mathrm{PO}_{4}\right)_{3}(\mathrm{OH})$ ".

Biological apatites (bioapatites) are carbonated non-stoichiometric Ca-deficient compounds, substituted with trace amounts of various ions, either adsorbed on the crystal surface or incorporated in the lattice structure $[1,2,5,32,50,51]$. As a constituent of bones, HA also contains $\mathrm{F}$ which partially substitutes the hydroxyl group, and impurities such as $\mathrm{Mg}, \mathrm{Na}$ or Si. Metals usually substitute one of the two crystallographic positions of $\mathrm{Ca}$, while Si substitutes $\mathrm{P}$. The valence differences between the host and substitute atoms are usually compensated by oxygen defects. In addition, the natural bone consists of carbonated HA, with the carbonate group replacing either the hydroxyl group-in this case the carbonated structure is called type- $\mathrm{A}$, or the phosphate group-denoted as type- $\mathrm{B}$ structure [52]. These two types of carbonated HA structures were intensively studied by different structural methods, but reliable results were obtained only on synthetic HA, since rigorous structural studies (e.g., by diffraction on single crystals) on natural HA are limited because of the very small dimensions of bone crystallites [46]. Typically, the type-A or type-B HA structures are verified by Fourier transform infrared (FTIR) spectrometry by the identification of the positions of the $v_{2}$ and $v_{3}$ stretching vibration modes of the carbonate groups [53]. The mineral bone substitutions with trace elements are considered reasons for the changes in crystallinity, solubility, and the overall biological responses.

Besides biological structures/systems, the mineral named apatite- $\mathrm{Ca}_{10}\left(\mathrm{PO}_{4}\right)_{6} \mathrm{X} 2, \mathrm{X}=\mathrm{F}^{-}, \mathrm{Cl}^{-}$ or $(\mathrm{OH})^{-}$is an important host material for rare earth elements, often present as substituent for Ca. 
The crystal symmetry of these minerals is hexagonal with space group $\mathrm{P} 63 / \mathrm{m}$, or, for some ordered varieties, monoclinic with space group P21/b [54].

The limitation in terms of autografts and allografts has led scientists to the development of various non-synthetic (e.g., natural resources: animal, aquatic, plants) [21,22,55-64] and synthetic doped/substituted HA as alternatives [5,65-68]. The first type of "doping" involves cationic substitution, where monovalent (e.g., $\mathrm{Ag}^{+}, \mathrm{Na}^{+}, \mathrm{K}^{+}$), bivalent (e.g., $\mathrm{Mg}^{2+}, \mathrm{Sr}^{2+}, \mathrm{Zn}^{2+}, \mathrm{Ba}^{2+}$ ), or multi-valent cations move in the lattice sites occupied by $\mathrm{Ca}^{2+}$. A second type of doping implies the anionic substitution, occurring either at the hydroxyl site (type-A substitution), at the phosphate site (type-B substitution), or as a mixture of both (type-AB substitution).

Important research activities have been devoted to substituted HA (SHA) compounds $[1,2,32,35$, $69,70]$, and a large variety of cation doped/substituted hydroxyapatite materials have been synthesized (Figure 2). The most intensively studied doping cations were $\mathrm{Sr}, \mathrm{Ag}, \mathrm{Zn}$, and $\mathrm{Mg}$, with frequencies of $\sim 17.5 \%, \sim 16.5 \%, \sim 15 \%$, and $13.9 \%$, respectively (Figure 2 -inset).

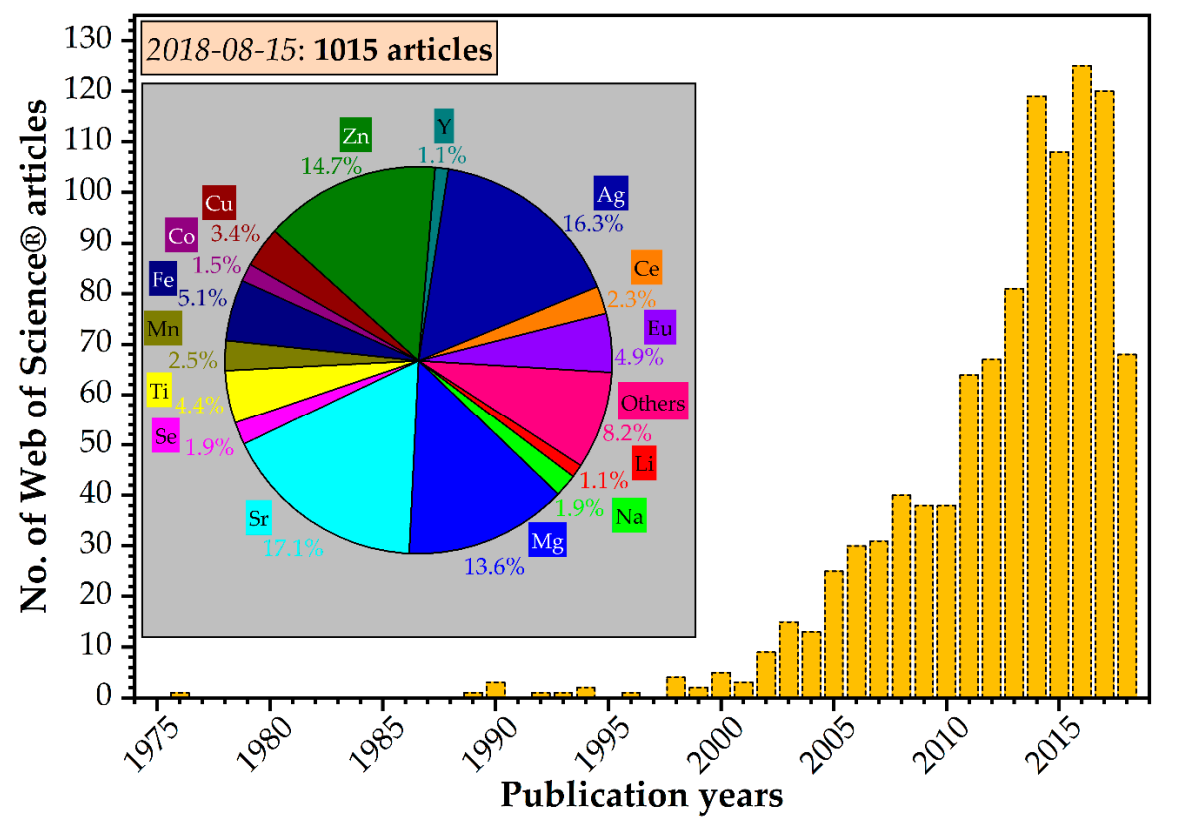

Figure 2. Yearly distribution of scientific articles published on the doped-substituted hydroxyapatite topic over the 1975-2018 period (15th of August 2018). Database: Clarivate Analytics-Web of Science ${ }^{\circledR}$ Core Collection. Coupled «title» and «topic» search keywords: "hydroxyapatite", "hydroxylapatite", "HA", "HAp", " $\mathrm{Ca}_{10}\left(\mathrm{PO}_{4}\right)_{6}(\mathrm{OH})_{2}$ ", "Ca $\left(\mathrm{PO}_{4}\right)_{3}(\mathrm{OH})^{\prime}$, "doped", and "substituted". Inset: Frequency of cation doping in hydroxyapatite.

The great variety of cation doping possibilities, of different ionic radii, is determined by the high lattice "flexibility", and good structural stability of hydroxyapatite [5,71,72]. Synthetically substituted HAs seem to possess a series of significant advantages over stoichiometric HA, imprinted by the structural (e.g., changes in the lattice constants and unit cell volume, generation of defects, particular surface charge distributions) and morphological modifications the cation doping is inducing $[1,2,32,35,69,73-76]$. For instance, the fracture toughness $\left(K_{I c}\right)$ is a decisive material property when developing reliable ceramic scaffold grafts for load-bearing applications. However, pure HA is a quite brittle material, with a $\mathrm{K}_{\mathrm{Ic}}$ value situated in the range of $0.5-1 \mathrm{MPa} \cdot \mathrm{m}^{1 / 2}$ [77], thus much lower than the cortical human bone which elicits $\mathrm{K}_{\mathrm{Ic}}$ performances in the range $2-12 \mathrm{MPa} \cdot \mathrm{m}^{1 / 2}$, depending on the direction of the applied mechanical load $[75,77,78]$. However, few reports have already hinted at the possibility of improving this specific mechanical property by controlled cation substitution in the HA lattice. Specifically, a $\mathrm{K}_{\mathrm{Ic}}$ value of $2.7 \mathrm{MPa} \cdot \mathrm{m}^{1 / 2}$ was achieved by doping HA with $0.6 \mathrm{wt} . \% \mathrm{Mg}$ [79]. S. Lala et al. [80] reported a fracture toughness improvement from $\sim 0.5 \mathrm{MPa} \cdot \mathrm{m}^{1 / 2}$ (in the case of pure HA) to values of $1.0,1.5$, and $1.6 \mathrm{MPa} \cdot \mathrm{m}^{1 / 2}$ when doping with 
5 at. $\% \mathrm{Mg}, \mathrm{Zn}$ and $\mathrm{Mn}$, respectively. Nonetheless, the data on the fracture toughness of doped HA are not abundant, and thereby further unambiguous explorations are needed to confirm or advance new doping possibilities able to improve the mechanical properties of HA, allowing for its safe use for load-bearing biomedical applications. Furthermore, the cation doping of HA started to be recognized for its ability to lead to improved biological properties such as bioactivity, surface reactivity, and adsorption of proteins/growth factors, while fostering biocompatibility, non-genotoxicity and ability to promote cell proliferation $[1,2,5,32,69,73,74,81]$.

As the overall biological performance of bone regeneration substitutes and implants relies on positive interfacial interaction with body media and the surrounding tissues immediately after the implantation, the biofunctional advances introduced by cation substitution of HA could prove of high significance for the biomedical field, and need to be emphasized, as they could pave the road toward an upgraded generation of bioceramic scaffold and implant coatings.

Moreover, the concerns generated by both the (i) appearance of microorganisms resistant to all known pharmaceutical antibiotics $[82,83]$ and (ii) increase of implant failure due to nosocomial infections with various pathogens [84], have lately driven the research into "equipping" the hydroxyapatite materials (by doping) also with antimicrobial defence mechanisms, with promising prospects, as will be shown in this review.

Thereby, justified by the ease of doping and the potential great biomedical benefits which could emerge from such scientific endeavours, hyper-active research has been dedicated to the cationic doping of HA, with the table of Elements serving as a playground for selecting either rational (based on the human bone trace elements) or exotic (e.g., lanthanides and actinides) cation dopants.

This review focused on the current status of the cationic-substituted HA materials, their derived and many times complementary biofunctional effects (with deep regard on their cytotoxicity and antimicrobial activity), as well as critically surveying the most used in vitro biological interrogation/ investigation assays and conceptual experimental designs, along with their ability to mimic the in vivo biological interactions. Conclusions will be drawn, future perspectives will be discussed, and a series of recommendations will be highlighted.

\section{Preparation Methods and Synthesis Routes of Hydroxyapatite Materials}

Bulk HA can be produced in various forms (e.g., nano-crystalline and micro-crystalline powders, granules, coatings) and shapes (e.g., spheres, platelets, needles, rods) from either synthetic or nonsynthetic (natural) resources, both having their advantages and limitations.

For example, the methods used to extract/prepare HA from natural (sustainable/renewable) resources are cheap and simple (in the case of bone waste). Furthermore, the as-fabricated HA materials are well-suited to achieve a good synergy with biological media since they already contain trace element substitutions [22,50,85-88]. However, such materials are dependent on the availability of natural resources and require a well-controlled calcination procedures and cleaning protocols to remove the organic moieties, and most importantly any bacteria or viruses [22,89-91]. A large palette of natural HA sources including animal bones (mammalian, fish), plants, and biogenic (egg-shell and sea-shell) sources have been employed in order to respond to escalating orthopaedic and dentistry demands [22,55]. It has been argued that HA obtained from natural resources exhibits properties and a biological response comparable or even better than the synthetic ones, due to their similitude with bone apatite [92]. HA prepared from natural resources such as bovine, sheep, pig, fish, egg-shell, sea-shell or marble contain trace amounts of cations such as $\mathrm{Na}^{+}, \mathrm{K}^{+}, \mathrm{Mg}^{2+}, \mathrm{Zn}^{2+}, \mathrm{Ba}^{2+}, \mathrm{or} \mathrm{Sr}^{2+}$ and anions such as $\mathrm{CO}_{3}{ }^{2-}$, or $\mathrm{SiO}_{4}{ }^{4-}, \mathrm{F}^{-}$or $\mathrm{Cl}^{-}$, which play crucial roles in biochemical interactions, bone regeneration and tissue engineering [55].

\subsection{Preparation of Bulk Hydroxyapatite (HA) from Natural Resources}

HA has been prepared from various animal-origin sources including bovines [57,58,89,93-98], pigs [99-101], camels [102], sheep [103-105], goats [94], and chickens [94,106,107]. A summary of the 
frequently utilized natural resources for the synthesis of hydroxyapatite materials is presented in Table 1.

Table 1. Preparation of hydroxyapatite (HA) from natural resources.

\begin{tabular}{|c|c|c|c|}
\hline Elements & Source & Synthesis Method & Refs. \\
\hline \multirow{3}{*}{ Bovine } & Cortical bone & $\begin{array}{l}\text { Pre-cleaning: (i) removal of soft tissue; (ii) cut into small pieces and boiled } \\
\text { in water for } 2 \text { to } 3 \mathrm{~h} \text {; (iii) dry in an oven at } 80^{\circ} \mathrm{C} \text { for } 72 \mathrm{~h} \text {; (iv) crush and } \\
\text { subsequently grind by ball milling for } 24 \mathrm{~h} \text {. } \\
\text { Heating: calcination in a furnace at temperatures in the range of } \\
600-1100{ }^{\circ} \mathrm{C} \text {, for } 3 \mathrm{~h} \text {, with heating and cooling rates of } 5^{\circ} \mathrm{C} \mathrm{min}^{-1} \text {. }\end{array}$ & [93] \\
\hline & Cortical bone & $\begin{array}{l}\text { Pre-cleaning: (i) removal of soft tissue; (ii) crushing and milling process. } \\
\text { Heating: sintering in a furnace at } 1200^{\circ} \mathrm{C} \text { for } 2 \mathrm{~h} \text { or } 4 \mathrm{~h} \text {, with a heating and } \\
\text { cooling rate of } 5^{\circ} \mathrm{C} \min ^{-1} \text { and } 10^{\circ} \mathrm{C} \min ^{-1} \text {, respectively. }\end{array}$ & [92] \\
\hline & Teeth & $\begin{array}{l}\text { Pre-cleaning: (i) removal of soft tissue; (ii) removal of remnant impurities by } \\
\text { mechanical scraping; (iii) boiling in distilled water for } 30 \mathrm{~min} \text {; }(i v) \text { repeated } \\
\text { the aforementioned steps three times; }(v) \text { drying in the sun for } 3 \text { days. } \\
\text { Heating: }(i) \text { calcination in humid atmosphere at } 735^{\circ} \mathrm{C} \text { for } 1 \mathrm{~h} \text { with a } \\
\text { heating rate of } 7^{\circ} \mathrm{C} \min ^{-1} ;(i i) \text { sintering at } 1150{ }^{\circ} \mathrm{C} \text { for } 1 \mathrm{~h} \text { with a heating } \\
\text { rate of } 7^{\circ} \mathrm{C} \min ^{-1} \text {. }\end{array}$ & [108] \\
\hline \multirow{2}{*}{ Pig } & Cortical bone & $\begin{array}{l}\text { Pre-cleaning: (i) hot water treatment; (ii) removal of organic compounds by } \\
\text { scraping; (iii) de-proteinization in a boiled mixture of } 1 \mathrm{M} \mathrm{NaOH} \text { and } 1 \mathrm{M} \\
\mathrm{HCl} \text { at } 100^{\circ} \mathrm{C} \text { for } 5-10 \mathrm{~min} \text {; }(i v) \text { dried in an oven at } 100^{\circ} \mathrm{C} \text { overnight; }(v) \\
\text { crushing and grinding. } \\
\text { Heating: calcination in air at } 600^{\circ} \mathrm{C}, 800{ }^{\circ} \mathrm{C} \text { or } 1000^{\circ} \mathrm{C} \text { at a heating rate of } \\
5^{\circ} \mathrm{C} \mathrm{min}^{-1} \text { followed by cooling to room temperature. }\end{array}$ & [99] \\
\hline & Cortical bone & $\begin{array}{l}\text { Pre-cleaning: (i) removal of soft tissues and fluids; (ii) boiling bone slices at } \\
154^{\circ} \mathrm{C}, 4 \mathrm{~atm} \text {; (iii) drying in vacuum; (iv) milling; (v) removal of remnant fat } \\
\text { and protein moieties by hydrothermal process. } \\
\text { Heating: (i) calcination at } 5{ }^{\circ} \mathrm{C} \mathrm{min}-1 \text { at } 600^{\circ} \mathrm{C} \text { (allows the decomposition } \\
\text { of organic tissue); (ii) sintering at } 1000^{\circ} \mathrm{C} \text { (induces physico-chemical } \\
\text { changes) from } 1 \text { to } 50 \mathrm{~h} \text {; (iii) cooling in the furnace in air. }\end{array}$ & [100] \\
\hline Camel & Cortical bone & $\begin{array}{l}\text { Pre-cleaning: (i) removal of organic compound; (ii) dry-heating at } 100{ }^{\circ} \mathrm{C} \\
\text { for } 1 \mathrm{~h} \text {; (iii) cut in small pieces and immersion in acetone for } 1 \mathrm{~h} \text {. } \\
\text { Heating: calcination at } 1000{ }^{\circ} \mathrm{C} \text { for } 3 \mathrm{~h} \text { at a heating rate of } 10{ }^{\circ} \mathrm{C} \mathrm{min}-1 \text {, and } \\
\text { then slowly cooled down to room temperature. }\end{array}$ & [102] \\
\hline \multirow{2}{*}{ Sheep } & Cortical bone & $\begin{array}{l}\text { Pre-cleaning: (i) removal of femoral heads; (ii) de-proteinization with } \\
\mathrm{NaOH} \text {; (iii) washing and drying. } \\
\text { Heating: (i) calcination at } 850^{\circ} \mathrm{C} \text { for } 4 \mathrm{~h} \text { in air; (ii) crushing and milling. }\end{array}$ & [103] \\
\hline & Dentine & $\begin{array}{l}\text { Pre-cleaning: cleaning and washing the teeth. } \\
\text { Heating: (i) calcination at } 750{ }^{\circ} \mathrm{C} \text { for } 5-6 \mathrm{~h} \text {; (ii) separation of dentine from } \\
\text { enamel; (iii) ball grinding; (iv) sintering at } 1000-1300{ }^{\circ} \mathrm{C} \text { for } 4 \mathrm{~h} \text {. }\end{array}$ & [109] \\
\hline Chicken & Egg-shells & $\begin{array}{l}\text { Pre-cleaning and synthesis: }(i) \text { crushing egg-shells; (ii) simultaneous } \\
\text { removal of organics and transformation of } \mathrm{CaCO}_{3} \text { into } \mathrm{CaO} \text { by calcination } \\
\text { at } 900^{\circ} \mathrm{C} \text { for } 1 \mathrm{~h} \text {; (iii) addition of water and phosphoric acid; (iv) } \\
\text { precipitation overnight, followed by filtration and washing; (v) drying the } \\
\text { HA product at } 60^{\circ} \mathrm{C} \text { for } 24 \mathrm{~h} \text {. } \\
\text { Heating: sintering in air (after sieving and pressing) at } 900-1300{ }^{\circ} \mathrm{C} \text { for } 1 \mathrm{~h} \text {, } \\
\text { with a heating rate of } 10^{\circ} \mathrm{C} \text {. }\end{array}$ & [110] \\
\hline Fish & Bones & $\begin{array}{l}\text { Pre-cleaning: (i) removal of organic compounds by brushing and then } \\
\text { boiling at } 100^{\circ} \mathrm{C} \text { for } 10 \mathrm{~min} \text {; (ii) drying at } 90^{\circ} \mathrm{C} \text { for } 100 \mathrm{~min} \text { and then } \\
\text { crushing to powder; (iii) de-proteinization by reflux method using a } 5 \% \\
\text { KOH solution. } \\
\text { Heating: sintering at } 600-1000^{\circ} \mathrm{C} \text {. }\end{array}$ & {$[111,112]$} \\
\hline Mussel & Shells & $\begin{array}{l}\text { Pre-cleaning and synthesis: }(i) \text { mechanical cleaning and calcination in air } \\
\text { at } 1300{ }^{\circ} \mathrm{C} \text { for } 6 \mathrm{~h}(\mathrm{ii}) \text { Rathje fabrication method: mixing seashells powder } \\
\text { with water and } \mathrm{H}_{3} \mathrm{PO}_{4} \text { with magnetic stirring during the synthesis for } 2 \mathrm{~h} \text { at } \\
700 \mathrm{rpm} \text {; (iii) filtering, followed by drying at room temperature for } 168 \mathrm{~h} \text {, } \\
\text { and then at } 100{ }^{\circ} \mathrm{C} \text { for } 24 \mathrm{~h} \text {. } \\
\text { Heating: sintering at } 1200^{\circ} \mathrm{C} \text { for } 10 \mathrm{~h} \text {. }\end{array}$ & [57] \\
\hline
\end{tabular}


Table 1. Cont

\begin{tabular}{|c|c|c|c|}
\hline Elements & Source & Synthesis Method & Refs. \\
\hline Snail & Shells & $\begin{array}{l}\text { Pre-cleaning and synthesis: }(i) \text { thoroughly cleaning of sand particles and } \\
\text { other foreign materials; (ii) drying, crushing into small particles, } \\
\text { ball-milling; (iii) sieving; (iv) mixing the as-obtained } \mathrm{CaCO}_{3} \text { powder with } \\
\text { water and } \mathrm{H}_{3} \mathrm{PO}_{4} \text { solution, followed by continuous stirring at } 80{ }^{\circ} \mathrm{C} \text { for } 8 \mathrm{~h} \text {; } \\
\text { (v) drying at } 100{ }^{\circ} \mathrm{C} \text { overnight in an incubator. } \\
\text { Heating: calcination at } 800^{\circ} \mathrm{C} \text { for } 4 \mathrm{~h} \text { in air. }\end{array}$ & [63] \\
\hline Cuttlefish & Whole & $\begin{array}{l}\text { Pre-cleaning and synthesis: (i) cutting into small pieces; (ii) heat-treatment } \\
\text { at } 110,500,1000{ }^{\circ} \mathrm{C} \text { with a heating rate of } 5^{\circ} \mathrm{C} \mathrm{min}^{-1} ;(\text { iii) mixing the } \\
\text { as-obtained } \mathrm{CaCO}_{3} \text { powder with an aqueous } \mathrm{NH}_{4} \mathrm{H}_{2} \mathrm{PO}_{4} \text { solution to a } \mathrm{Ca} / \mathrm{P} \\
\text { molar ratio of } 1.67 ;(\mathrm{v}) \text { drying at } 200{ }^{\circ} \mathrm{C} \text { for } 1-72 \mathrm{~h} \text {, using heating and cooling } \\
\text { rates of } 5{ }^{\circ} \mathrm{C} \mathrm{min}^{-1} \text {. }\end{array}$ & [60] \\
\hline $\begin{array}{c}\text { Dolomic } \\
\text { marble }\end{array}$ & $\begin{array}{l}\text { Origin: } \\
\text { Ruschița, } \\
\text { Romania }\end{array}$ & $\begin{array}{l}\text { Pre-cleaning and synthesis: }(i) \text { mechanical cleaning and calcination in air } \\
\text { at } 1300{ }^{\circ} \mathrm{C} \text { for } 6 \mathrm{~h}(\mathrm{ii}) \text { Rathje fabrication method: mixing seashells powder } \\
\text { with water and } \mathrm{H}_{3} \mathrm{PO}_{4} \text { with magnetic stirring during the synthesis for } 2 \mathrm{~h} \text { at } \\
700 \mathrm{rpm} \text {; (iii) filtering, followed by drying at room temperature for } 168 \mathrm{~h} \text {, } \\
\text { and then at } 100{ }^{\circ} \mathrm{C} \text { for } 24 \mathrm{~h} \text {. } \\
\text { Heating: sintering at } 1200^{\circ} \mathrm{C} \text { for } 10 \mathrm{~h} \text {. }\end{array}$ & [57] \\
\hline $\begin{array}{c}\text { Red } \\
\text { algae }\end{array}$ & Whole & $\begin{array}{l}\text { Pre-cleaning: (i) rinsing at high-pressure; (ii) drying at room temperature } \\
\text { for } 24 \mathrm{~h} \text {; (iii) sieving; (iv) thermal treatment to burn-off the organic material, } \\
\text { at } 650-700{ }^{\circ} \mathrm{C} \text { for } 12 \mathrm{~h} \text {, with a low heating rate of } 0.5^{\circ} \mathrm{C} \text { min }-1 \text { to prevent } \\
\text { decomposition of algae; }(v) \text { alkalinisation with ammonium hydroxide at } \\
\text { ambient pressure and } 100{ }^{\circ} \mathrm{C} \text { for } 12 \mathrm{~h} \text { under continuous stirring at speed of } \\
100 \mathrm{rpm} \text {; (vi) filtration and neutralisation by repeating washing and drying } \\
\text { overnight at } 90^{\circ} \mathrm{C} \text {. } \\
\text { Heating: thermal treatment at } 60^{\circ} \mathrm{C}, 105^{\circ} \mathrm{C}, 450{ }^{\circ} \mathrm{C}, 550{ }^{\circ} \mathrm{C} \text { and } 1000{ }^{\circ} \mathrm{C} \text { for } \\
1 \mathrm{~h} \text { each. }\end{array}$ & [113] \\
\hline
\end{tabular}

Bovine and swine bones seem to be the preferred animal resources for biological HA production $[22,57,58,89,96,97,114]$. Animal bone-derived HA is typically prepared by a three-stage process: (i) mechanical scraping of soft tissue; (ii) deproteinization in alkali media; (iii) calcination at temperatures able to remove any remnant organic and biological hazardous components. HA derived from animal bone has generally a low degree of crystallinity, and usually calcination between 600 and $1100{ }^{\circ} \mathrm{C}$ has been found to be the best choice to improve the degree of crystallinity with excellent thermal phase stability [55,88]. Rincón-López et al. [92] compared the physical and chemical properties of cortical bovine HA (BHA) with a commercial synthetic HA and observed that although they have different crystalline size and morphology due to the ionic substitution (e.g., $\mathrm{Na}^{+}, \mathrm{Mg}^{2+}, \mathrm{CO}_{3}{ }^{2-}$ ) in BHA, both samples exhibited similar biological activity in terms of biocompatibility and non-toxicity in human osteoblast cell cultures.

Egg-shell structure, which has been frequently described in the literature, is mainly composed of calcite (94-95\%) with trace amounts of inorganic components, such as magnesium carbonate or calcium phosphates [115]. The synthesis of HA from egg-shells is generally achieved by ball-milling and subsequent sintering procedures [115].

Aquatic bones and shells are reliable sources for the production of HA since they contain a high content of minerals, such as calcium carbonate in the form of calcite or aragonite, silica and calcium phosphate [22,60-64,116-118]. Two main routes are generally used to convert marine-origin material to HA: (i) hydrothermal synthesis and (ii) hydrothermal hot-pressing. Hydrothermal synthesis involves heating processes under alkaline conditions at a specific temperature and pressure, while hydrothermal hot-pressing involves supplementary a compacting process. The temperature used for calcination and alkaline treatment are crucial parameters influencing the crystallinity, grain size and specific surface area of the final product [22]. The optimal preparation temperature ranges between $200-250{ }^{\circ} \mathrm{C}$. In contrast to the HA derived from bovine bones, HA prepared from aquatic sources is reported to be thermally stable at a temperature up to $1200{ }^{\circ} \mathrm{C}$ [22]. 
One of the advantage of non-synthetic HA routes in comparison to the synthetic HA fabrication methods is their lower cost [22,55]. In this sense, the production of HA from various wastes is an equally excellent and promising alternative [22]. For example, the use of egg-shell or sea-shell wastes, which represent the most abundant by-products of the food industry, has been found as a very promising sustainable resource to produce HA at a low cost with little impact to the environment [88,119-121]. Apart from the method of synthesis, the quality of non-synthetic HA (e.g., purity, grain size, properties) is strongly dependent on the biological source, location, age and fabrication process $[1,55,92-94,99,100$, $104,109,111,112,116]$.

Another major advantage of this fabrication route of HA materials is the extremely low risk of immune reactions. In order to trigger an immune response, the antigen-presenting cells in the body need to find an organic compound that is identified as non-self, usually a protein/peptide or an oligosaccharide with a specific sequence. As previously mentioned, in the process of preparing animal-bone derived HAs, all organic compounds are completely destroyed by the high processing temperatures. The inorganic component of animal-bone HA is similar to the major mineral phase of human bone, thus being safe from immune responses. However, if one further dopes biological HA with low quantities of various cations (e.g., $\mathrm{Cu}, \mathrm{Co}, \mathrm{Cr}, \mathrm{Ni}, \mathrm{Ag}$ ), rare allergic reactions could occur due to the fact that such ions act as haptenes [122] (as after binding normal proteins they modify their conformation forcing the immune system to act against them as non-self material).

\subsection{Synthesis of Bulk Synthetic Substituted HA}

Synthetic routes, even though costlier, offer the possibility to fine tune the properties of HA by cation and/or anion substitution, in order to boost its sustainability for specific applications (e.g., dental implants could be subjected to more acidic environment) and long-term performance.

The physico-chemical properties of substituted synthetic HAs (SHA) are extremely sensitive to the processing conditions and type of preparation method. The final features of synthesized HA (e.g., morphology, structure/crystallinity, composition, porosity, mechanical features and biological properties) will have a great influence on the overall in vivo performance of the bioceramic.

SHAs have been prepared by different methods, such as wet-chemistry methods (e.g., co-precipitation, hydrothermal, sol-gel), solid-state reaction, combustion, microwave and mechanochemical synthesis $[1,2,5,6,32,69,123-126]$. The advantages and limitations of the HA fabrication methods, as well as their ability to produce bioceramics of different shapes and crystalline quality, were insightfully reviewed by Mucalo [91], Fihri [6], and Sadat-Shojai [127].

The most widely used synthesis methods are the wet-chemistry ones, with emphasis on the co-precipitation from the solutions of calcium, phosphate and selected dopant salts $[1,5,6,126]$. The co-precipitation method, working at temperatures ranging from room temperature to $-200{ }^{\circ} \mathrm{C}$, usually provides nanocrystalline HA, thereby with high specific surface area $[126,128]$. Nevertheless, it was demonstrated that the size and shape of HA powder particles, prepared by co-precipitation, can be controlled/tailored by reactants involved in synthesis, concentration of solutions, $\mathrm{pH}$ of the environment reaction, acid addition rate, reaction temperature, and/or post-synthesis thermaltreatment $[2,6,127]$. Generally, in order to obtain doped HA with good crystallinity, the addition of the reactants requires intense stirring, while the time of maturation of the precipitate should be longer. The crystal shapes can be controlled by the reaction temperature $[2,6,127,129]$.

\subsection{Fabrication of Substituted HA Coatings}

The poor mechanical properties of HAs have limited their stand-alone use to non-extreme load biomechanical bearing applications $[34,130,131]$. The coating of metallic implants and endo-prostheses with HAs has provided the opportunity to combine the excellent mechanical performances of the substrate with the superior biological properties of HAs (with emphasis on its ability to form a rapid and strong interfacial bonding with the host bone). Consequently, the implant-type coatings represent nowadays one of the prominent clinical applications of HA, and the only current use in load-bearing implantable devices. 
Bioactive HA coatings have been applied to both metallic [1,2,35] and thermoplastic polymers (e.g., PEEK-polyetheretherketone) [132] substrates. SHAs could effectively improve the biological performance of metallic implants, when applied as coatings, due to their superior properties provided by the controlled doping [20,35].

Nowadays, the commercial solution for producing HA implant coatings on titanium substrates is plasma spray. Although this implant design had certain clinical success [133-136], it is marred by a series of deficiencies which raise queries about its long-term operation: due to their typical high thickness $(>50 \mu \mathrm{m})$ the implant coatings are susceptible to poor adherence and delamination, whilst the high-temperature process often induces residual phases with unpredictable degradation rates in the internal body media. Currently, a plethora of coating techniques exist as possible alternatives. HA coatings were fabricated by sol-gel $[137,138]$, electrophoresis (EPD) $[137,139,140]$, electro-chemical deposition (ECD) [141,142], ion-beam assisted deposition [132,143], micro-arc oxidation [144,145], and biomimetic deposition from supersaturated simulated body media solution [146-148]. Emerging synthesis approaches include physical vapour deposition techniques such as: magnetron sputtering [35, $67,68,70,131,135,149-151]$, pulsed laser deposition (PLD) $[35,89,97,98,105,135]$, pulsed electron deposition [35,135,152-155], and matrix-assisted pulsed laser evaporation [117,135,156-159]. The advantages and limitations of each technique have been reviewed insightfully by Narayanan and Bosco et al. [160,161] and Surmenev [131]. Both biological [89,97,98,153,154] and synthetic HAs [131] have been used as source materials for the fabrication of implant coatings.

Significant efforts have been devoted to the fabrication of reliable coatings, and from the total of published papers, this specific HA niche represents more than 14\% (Figure 3) of the research works. When comparing the most used deposition techniques, it is evident that the thermal spray family (here including plasma spray, cold spray, detonation spray, flame spray, high-velocity oxy-fuel spray, high-velocity atmospheric spray, and high-velocity suspension flame spraying) was the prominent research choice, followed by the EPD and ECD methods (Figure 3-inset). All the mentioned deposition technique variants can be adopted for the fabrication of SHA coatings.

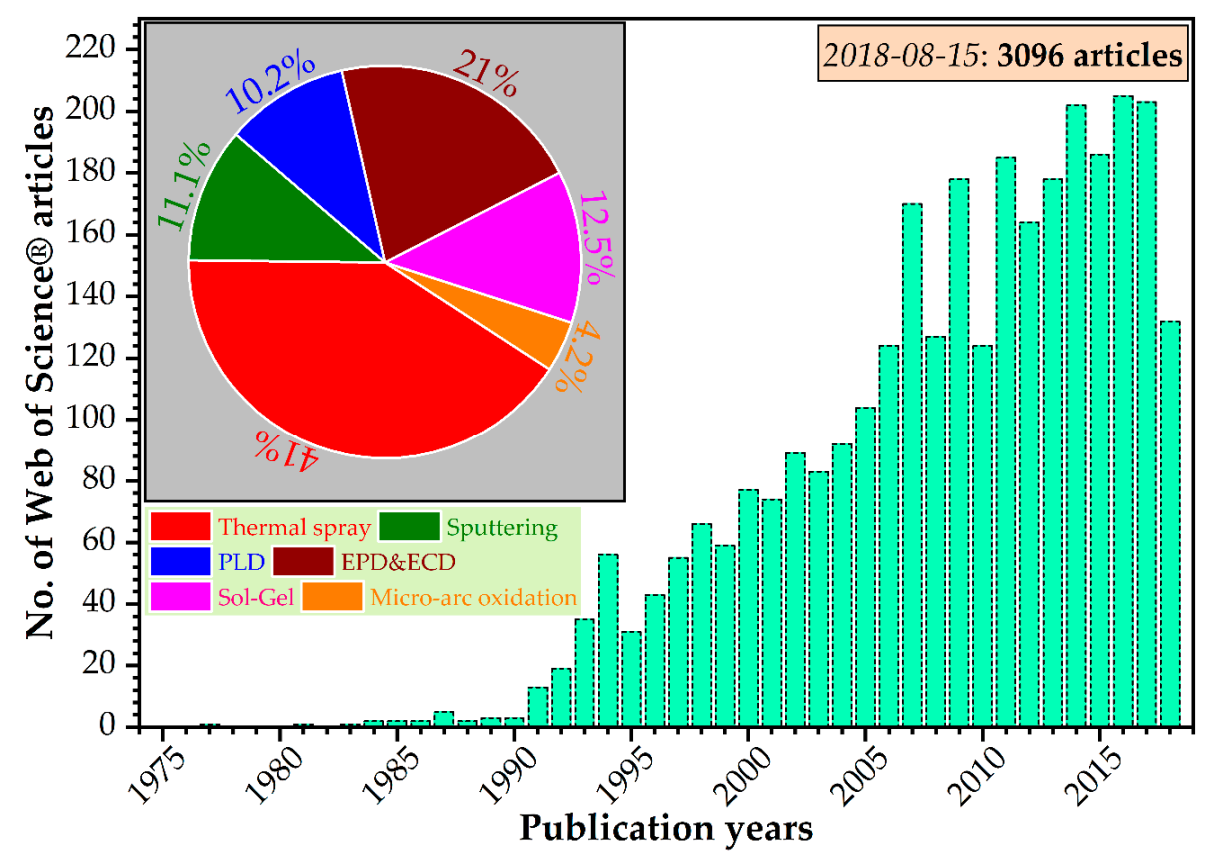

Figure 3. Yearly distribution of scientific articles published on the hydroxyapatite coatings topic over the 1975-2018 period (15th of August 2018). Database: Clarivate Analytics-Web of Science ${ }^{\circledR}$ Core Collection. Coupled «title» and «topic» search keywords: "hydroxyapatite", "hydroxylapatite", "HA", “HAp", " $\mathrm{Ca}_{10}\left(\mathrm{PO}_{4}\right)_{6}(\mathrm{OH})_{2}$ ", “ $\mathrm{Ca}_{5}\left(\mathrm{PO}_{4}\right)_{3}(\mathrm{OH})^{\prime}$, "coating”, "film”, and "layer". Inset: Frequency comparison of the most used technologies for coating fabrication. 


\section{Cation-Substituted Hydroxyapatites}

Besides the biomedical field usage, which will be comprehensively reviewed in the following, cation-substituted HAs have been envisaged to be employed in a variety of other type of applications (Table 2).

Table 2. Other fields of applications for cation-substituted hydroxyapatite.

\begin{tabular}{cc}
\hline Cation Dopant & Field of Application [Refs.] \\
\hline $\mathrm{Na}$ & Sensors [162]; Catalysis [163] \\
$\mathrm{Sr}$ & Catalysis [164] \\
$\mathrm{Ba}$ & Water decontamination [165]; Catalysis [166] \\
$\mathrm{Al}$ & Environment decontamination [167-169]; Catalysis [170] \\
$\mathrm{Sn}$ & Radionuclides and heavy metals scavengers (decontamination) [171] \\
$\mathrm{Pb}$ & Catalysis [172,173] \\
$\mathrm{Y}$ & Electrochemical devices [174] \\
$\mathrm{Ti}$ & Catalysis [175-177] \\
$\mathrm{V}$ & Catalysis [178] \\
$\mathrm{Mn}$ & Catalysis [179]; Optoelectronics [180] \\
$\mathrm{Fe}$ & Sensors [181]; Catalysis [182,183] \\
$\mathrm{Co}$ & Sensors [184] \\
$\mathrm{Ni}$ & Catalysis [185-188] \\
$\mathrm{Pd}$ & Catalysis [189,190] \\
$\mathrm{Pt}$ & Catalysis [191,192] \\
$\mathrm{Cu}$ & Catalysis [198-200] \\
$\mathrm{Ag}$ & Catalysis [194,201,202] \\
$\mathrm{Au}$ & Catalysis [203-205] \\
$\mathrm{Zn}$ & Optoelectronics [206] \\
$\mathrm{Sm}$ & Catalysis [193-196]; Water decontamination [197] \\
$\mathrm{Eu}$ & Optoelectronics [206] \\
$\mathrm{Gd}$ & Optoelectronics [211] \\
$\mathrm{Tb}$ & \\
$\mathrm{Dy}$ & Catalysis [209]; Optoelectronics [210] \\
\hline
\end{tabular}

In the framework of this review the cation dopings were categorised with respect to the table of Elements nomenclature of "blocks", thereby, based on their electronic configuration (i.e., the highest-energy electrons for each cation species in a block belong to the same type of atomic orbital).

\section{1. s-Block Cation-Substituted Hydroxyapatites}

Lithium ( $\mathrm{Li})$ is present in organisms as trace metal and it is also used as treatment in psychiatry (for bipolar disorder) or for haematological conditions (e.g., neutropenia, aplastic anaemia). Li compounds can be prescribed as prophylactic or adjuvant in the treatment of leukopenia or thrombocytopenia induced by chemotherapy [212,213]. Moreover, Li treatment is involved in haematopoiesis by enhancing the production of G-CSF (granulocyte colony stimulating factor) and by stimulating the proliferation of pluripotent stem cells [214]. Importantly, Li has also demonstrated a positive role in bone biology [215], boosting fracture healing by activating the canonical Wingless integrated (Wnt)/ $\beta$-catenin signalling pathways that are important in the inflammatory phase of fracture repair [216-220]. Since the Wnt pathways are activated, the differentiation of mesenchymal progenitor cells into osteogenic agents will be successfully induced.

Li-HA showed a lower degradation rate than pure HA in simulated body fluid (SBF), whilst still inducing the in vitro formation of a biomimetic apatite layer [221]. Li-doped HA scaffolds showed efficient osteoblast proliferation and enhanced viability when tested in vitro and also revealed good osteogenesis and angiogenesis potential when studied in vivo (on Japanese white rabbits) [221,222]. By doping $\mathrm{HA}$ with $\mathrm{Li}^{+}$, the osseointegration is accelerated and the anchorage of bone metallic implants to host tissue is improved [89]. At the studied concentrations ( $\leq 2 \mathrm{at} . \% \mathrm{Li}), \mathrm{Li}-\mathrm{HA}$ showed 
good biocompatibility, without traces of cytotoxicity [221-223]. The in vivo tests on animal model (rabbit) demonstrated the capability of Li-doped (1.5 at.\%) HA scaffolds to induce the formation of new bone with well-defined trabeculae, as evidenced by histological detection of haematoxylin and eosin and Masson staining [224].

Sodium $(\mathrm{Na})$ is a very important electrolyte in all the living organisms. In humans it has vital roles in transmission of nerve impulses, muscle functions, regulation of fluid balance, heart activity and in bone metabolism [225-228]. As a dopant in $\mathrm{HA}, \mathrm{Na}^{+}$enhances the biomineralization capacity (i.e., carbonated hydroxyapatite formation) in SBF [227,229] and increases the coating adhesion on reinforced carbon fibres [229]. Na-HA coatings are biocompatible (when tested on mouse skull osteoblastic cells, MC3T3-E1), increasing cell proliferation [229]. Microscopy investigations showed an enhanced osteoconduction of Na-HA with respect to pure HA, highlighted by the formation of a thick and dense new bone in the calvarial defects of rabbits 4 weeks after implantation [227].

Potassium (K) is known as a beneficial element for dental health since it influences the apatite nucleation and biomineralization processes [230]. Incorporating $\mathrm{K}^{+}$in HA will positively affect the thermal stability [231]. K-doped HA is beneficial for protein adsorption and it could be used in needle-free trans-dermal delivery vehicles for proteins/antigens [232,233].

Magnesium (Mg), the fourth most abundant cation in the human body, has a high biocompatibility with living cells and an important role in bone health by stimulating osteoblast proliferation at the early stages of osteogenesis [234]. Deficiency of Mg causes bone loss. Mg-substituted (5.7 at.\%) HA has a comparable composition, morphology and crystallinity to the biological apatite, without cytotoxic effects [5,235]. $\mathrm{Mg}$ doping might induce a partial decomposition of the HA into $\beta$-tricalcium phosphate in the temperature range $650-1000{ }^{\circ} \mathrm{C}$ [234]. The Mg doping effect on biological properties of HA was tested on a wide palette of compositions: $1-53$ at.\% $\mathrm{Mg}$ (with respect to [Mg/(Mg + Ca)]-100]) [236-240]. $\mathrm{Mg}$ is also a prominent constituent of biodegradable metallic implants due to its biocompatibility and biodegradability in the physiological environment $[2,241]$.

The formation of a biomimetic apatite-like layer was found to be stimulated in SBF solution by increasing the $\mathrm{Mg}$ doping concentration in HA from 1 to 3 at.\% [242]. Mg-HA structures ensured endothelial and osteoblast (OBs) cells survival and spreading, improved OBs adhesion and promoted cell proliferation $[236,240]$. By contrast with most biocompatibility studies performed on several type of cell lines [236,239,240,243], Lima et al. found that Mg-HA materials induced apoptosis of human monocytes (isolated from blood) at doping concentrations as low as 1 at.\% [238]. However, the high dissolution rate of Mg-HA still needs to be addressed, since it influences the cell viability and overall cytotoxicity [1,67]. Mg-HA showed bactericidal effects against Gram-positive (Staphylococcus aureus) and Gram-negative bacteria (Pseudomonas aeruginosa and Escherichia coli) at doping concentrations starting from $\sim 6$ at.\% [237]. The in vivo tests on animal models (New Zealand White rabbits) indicated that Mg-doped (15 at.\%) HA used as filling for femoral bone defects had enhanced osteoconductivity with respect to the commercial stoichiometric HA [235].

Strontium (Sr) is one of the most promising doping cations, since it is able to promote osteoblast cell proliferation and stem cell differentiation, therefore enabling new bone formation and fostering significant roles in osseointegration [243-246]. Being a trace element in natural bone (more abundant in new bones than in aged ones), $\mathrm{Sr}^{2+}$ is easily incorporated and accepted by tissues. Strontium ranelate (SrR) has been administered widely as a treatment for osteoporosis [247], due to its ability to boost osteoblasts proliferation and reduce osteoclast differentiation, allowing for accelerated bone healing even for elderly patients [215]. SrR influences NF-KB and Wnt/b-catenin signalling pathways in the mesenchymal stem cells, promoting the proliferation of osteoprogenitor cells [248,249]. SrR can also stimulate angiogenesis through the PI3K/AKT/mTOR signalling pathway [248].

Sr doping in HA was tested over a wide concentration range (1-40 at.\%) [240,244-246,250]. The ability of Sr-HA to induce an enhanced formation of biomimetic apatite was demonstrated both in SBF [246,251,252] and cell culture medium (i.e., modified Eagle's medium) [244]. Regardless of Sr content, no signs of cytotoxicity were reported, with Sr-HA unanimously promoting osteoblasts 
proliferation and differentiation, corroborated with mitigation of the osteoclasts activity. Furthermore, the in vitro biological effect of Sr-doped HA bone cements on mesenchymal stem cells (MSCs) and OBs suggested that the bioceramic was able to respond with great specificity to each type of cell $[240,244,245,247,253]$. Besides preventing bone resorption by reducing the osteoclasts activity [245], Sr doping improves the mechanical properties of HA [250,254-256]. The in vivo tests in animal model (JW rabbits) coupled with optical microscopy (following hematoxylin and eosin and Masson staining) and micro-computed tomography studies, showed that higher volumes of new bone are formed in the case of Sr-HA-based scaffolds with respect to pure HA ones [257]. Similarly promising results were obtained also when performing in vivo tests on rats, with Sr-HA being able to reduce the area of calvarial bone defects and induce the formation of a denser bone tissue with respect to the pure HA groups [249].

Barium (Ba) has been used in dental cements as filling agents in root canals, due to its excellent mechanical properties and low cytotoxicity [258-260]. But, to date, there is only one paper that studied Ba-doped HA (mono-doping) for biological applications [261]. In this study, the Ba-HA antimicrobial activity was tested against S. aureus, Bacillus megaterium DMS 32, E. coli, Klebsiella pneumonia, and Candida albicans, but no relevant efficacy against these pathogen colonies was noticed [261]. The in vitro bioactivity tests performed in SBF on pure and Ba-doped (4 and 10 at.\%) bi-phasic calcium phosphates (91 wt.\% HA $+9 \mathrm{wt} . \% \beta$-tricalcium phosphate), disclosed an increased formation of biomimetic apatite with the Ba concentration [262].

\section{2. p-Block Cation-Substituted Hydroxyapatites}

There are only a few p-block elements that were tested as cation dopant in HA: aluminium, gallium, indium, bismuth, and tellurium.

Aluminium (Al) doping in HA had been proposed for its potential use in biomedicine, due to good biocompatibility in mouse fibroblasts cell cultures. It was highlighted that the cell viability decreases gradually with the increasing $\mathrm{Al}^{3+}$ concentration (tested in the range 0.5-2.5 at.\%) and incubation time. Al-HA is biocompatible when added in an amount up to $1 \mathrm{mg} \mathrm{mL}^{-1}$ [263].

Gallium (Ga) seems to not substitute $\mathrm{Ca}^{2+}$, but it enters on interstitial positions or it is adsorbed/ chemisorbed on the particles surface [264,265]. Regardless of its site occupancy in the HA lattice or surface, $\mathrm{Ga}^{3+}$ is a promising candidate for biomedical applications due to its demonstrated Ga-HA biocompatibility (in RAW264.7 cell cultures) and inhibitory antibacterial effect on P. aeruginosa [264,266].

Indium (In) doping of HA improved the osteoblasts activity by increasing their adhesion and differentiation rates [267].

Bismuth (Bi) doped HA was found to be cytocompatible with human osteoblasts [267], but induced certain levels apoptosis of human blood monocyte [238]. $\mathrm{Bi}^{3+}$ is normally not found in the human body, but when doping HA with Bi the adherence and differentiation of OBs could be enhanced. Bi-HA possesses the ability to induce the formation well-developed bone-like apatite layers after 1 month of immersion in SBF [268]. $\mathrm{Bi}^{3+}$ doping increased the dissolution rate of $\mathrm{HA}$ and elicited an antibacterial effect against $S$. aureus and E. coli, which makes Bi-HA a pertinent candidate for bone implant applications $[267,269]$. Bi-HA (scaffold)—polyurethane (matrix) composites were tested both in vitro (human osteoblast-like cells, MG63) and in vivo (in rabbits-subcutaneous and in intraosseous tibia sites) [268]. Excellent mechanical properties, antimicrobial activity against various pathogens, high osteoconductivity and in vitro biocompatibility was revealed. The in vivo investigations demonstrated the osteogenic potential of Bi-HA-polyurethane composite, with the authors advocating for a proper biomimetic microenvironment for bone regeneration with excellent cytocompatibility [268].

Tellurium $(\mathrm{Te})$ is a metalloid element that has antioxidant and pathogen-inhibiting features $[270,271]$. The use of Te as a low-level doping element in HA promoted antimicrobial activity against Grampositive (S. aureus, Bacillus subtilis, Micrococcus sp.) and Gram-negative (P. aeruginosa, Klebseilla sp., Proteus mirabilis, Shigella dysenteriae) bacteria and fungi (Candida albicans) [272]. However, more 
insightful biocompatibility studies should be performed for Te-HA materials, prior to drawing a safe conclusion on their potential for biomedical applications.

\section{3. d-Block Cation-Substituted Hydroxyapatites}

Silver (Ag) is known to be a highly effective inhibitory or antimicrobial agent for Gram-positive and Gram-negative bacteria, as well as for fungi [250,261,273-283]. This dopant is preferred for HA applications in dentistry and orthopaedics, where the hazard of implant infections has a high rate. In this respect, the long-term release of $\mathrm{Ag}^{+}$ions [284], could be an optimal solution. The main issue that needs to be carefully addressed is the cytotoxicity of $\mathrm{Ag}^{+}$, in order to determine the trade-off concentration values that will be both effective against microbes and safe for host tissues. Several studies investigated the toxic effect of $\mathrm{Ag}^{+}$on pathogens and on various cells culture lines $[250,273,280$ 283]. Although there is some dispersion in the tested compositions of Ag-HA (0.5-5 at.\%), it seems that the optimum silver doping is situated below the 2 at. $\%$ threshold $[250,273,280-283]$. The fabrication or preparation of Ag-doped HA have also an influence on its biological activity. Ag-HA coatings with a Ag content of $\sim 1.7$ at.\%, synthesized by plasma spray, had highly effective bactericidal properties against $P$. aeruginosa, but also a slight cytotoxic effect on human osteoblast $h F O B 1.19$ cell line, with cells showing premature apoptosis, delayed differentiation or even death [250]. In the case of processed powder forms of Ag-HA, the biocompatibility with human osteoblast cells was not affected by $\mathrm{Ag}$ content (at concentrations up to 1.5 at.\%), while maintaining a bacteriostatic effect [280]. Although the antimicrobial properties of Ag-HA were thoroughly investigated, the cytotoxicity coupled with the ion release rates has not been too frequently addressed $[274-279,281]$. The antibacterial spectrum of $\mathrm{Ag}-\mathrm{HA}$ is very wide, but still there are some pathogens that are not affected by $\mathrm{Ag}^{+}$, such as $\mathrm{B}$. subtilis, Enterococcus faecalis (ATCC 29212) [275] and Serratia marcescens (0804) [276]. In vivo evaluation of Ag-HA efficiency against Methicillin-resistant S. aureus (MRSA) was performed on Sprague-Dawley rats [283]. The Ag-HA implants reduced the MRSA biofilm formation, without inducing argyria (or any other kind of skin disorder) or being harmful to brain, kidney, liver or spleen. Furthermore, a good biomineralization capacity was disclosed for Ag-doped (0.13-5 at.\%) HA by in vitro assays performed in SBF [285] and McCoy culture medium [286].

Zinc $(\mathrm{Zn})$, besides being one the most abundant trace cation of bones, plays a crucial part in several body functions, markedly being a cofactor in hundreds of enzymes involved in bone functions and metabolism. Doping HA with $\mathrm{Zn}^{2+}$ increased the osteoblast cells viability, adhesion, spreading, proliferation and differentiation, and stimulated osteogenic activity, bone in-growth and healing [243, 267,287-289]. Restoration of normal $\mathrm{Zn}^{2+}$ and citrate levels have been observed to improve the bone quality in age-related osteopenia. High osterix levels (induced by the activation of runt-related transcription factor 2-Runx2) determines the increase of ZIP1 transporter activity, thus elevating the intracellular Zn levels [290]. Furthermore, the high Zn levels have been linked to the high concentrations of citrate in the extracellular matrix, leading to a rapid formation of HA and citrate incorporation into HA [290]. In some situations, the incorporation of $\mathrm{Zn}$ in HA powders had a toxic influence on cells (i.e., HepG2 cells—human hepatocytes [65,291]), as a consequence of Zn-HA particle sedimentation over cells. Excellent bioactivity of Zn-doped (2.4 at.\%) HA was evidenced after only 3 days of soaking in SBF solution [292]. Zn-doped HA was confirmed as an effective antimicrobial agent against Gram-positive and Gram-negative bacteria frequently occurring at the implant site: e.g., S. aureus, Streptococcus mutans, Staphylococcus epidermidis, Enterobacter aerogenes, E. coli $[65,274,288,289,291,293-295]$. The $\mathrm{Zn}^{2+}$ release acted against fungal infection, the $72 \mathrm{~h}$ C. albicans biofilms being strongly reduced at $\mathrm{Zn}$ concentration of 3 at.\% [277]. However, in dark conditions, at a lower $\mathrm{Zn}$ content (i.e., 1 at.\%) the number of $C$. albicans cells was also noticeably decreased [296]. Zn-HA was proficient in the case of cold-light bleaching-treated enamel remineralisation [289]. $\mathrm{Zn}^{2+}$ doping had a positive effect on the inhibition of bacterial plaque formation on enamel and on the improvement of the enamel remineralisation in dental prosthetic restoration. However, at high $\mathrm{Zn}$ concentrations $(\geq 2$ at.\%) the biocompatibility was affected, even though Zn-HA was efficient against enamel bacteria 
growth (S. mutans, Lactobacillaceae, and Streptococcus sobrinus), whereas 1 at.\% of Zn doping enhanced both osteoblast proliferation and antibacterial properties. The vast majority of Zn-doped HA is confined in the $0.1-4$ at.\% [Zn/(Zn + Ca) ·100] doping range [66,243,274,277,281,287,291,293,296]. However, the influence of higher zinc content (up to 50 at.\% as $[\mathrm{Zn} /(\mathrm{Zn}+\mathrm{Ca}) \cdot 100])$ on the biological activity of HA was also reported $[288,294]$. The best results in terms of biocompatibility, osteoconductivity and antimicrobial activity seem to be achieved for $\mathrm{Zn}^{2+}$ concentrations of $\sim 1-2$ at.\% [243,274,282,288,289]. Remarkably, the in vivo tests on animal model showed the Zn doping capability to enhance the new bone formation in comparison to pure HA, when implanted in rats [297] and rabbits [298], for one and two months, respectively.

Copper $(\mathrm{Cu})$ is an important micronutrient in organisms, being involved in the metabolic processes and in the proper functioning of organs. Cu-doped HA is an acknowledged antimicrobial agent, acting against both Gram-positive (S. aureus) and Gram-negative (E. coli) bacteria, as well as fungi (C. albicans) [299,300]. The antibacterial activity of Cu-HA powders seems to be highly dependent on the doping concentration: low $\mathrm{Cu}^{2+}$ content $(<0.5$ at.\%) was efficient in combating the Gram-negative bacteria [300,301], while the Gram-positive microorganisms are sensitive only to higher $\mathrm{Cu}$ doping level ( 2 at.\%) [299]. The antimycotic effect is revealed from low to high $\mathrm{Cu}^{2+}$ concentration $\sim 0.4-5$ at. $\%$ [299,300]. $\mathrm{Cu}^{2+}$ ions released from Cu-doped ( 2.4 at.\%) HA coatings have a strong bactericidal effect against E. coli colonies (bacteria cells were reduced by more than 75\%) [302]. In addition to antimicrobial behaviour, the doping of $\mathrm{HA}$ with $\mathrm{Cu}$ might be beneficial for inducing protein adsorption, osteogenic differentiation, bone-like apatite nucleation and growth at the implant site [302,303]. For instance, the superior bioactivity of Cu-doped (2.4 at.\%) HA with respect to the pure compound was demonstrated by Huang et al. [302] after 10 days of immersion in SBF. Moreover, HA coating doped with low $\mathrm{Cu}^{2+}$ contents ( 2 at.\%) exhibited good cytocompatibility toward mouse skull osteoblasts (MC3T3-E1). An IP6-assisted hydrothermal method was used to fabricate Cu-HA nanoparticles, with a theoretical $\mathrm{Cu}$ concentration of $\sim 5$ at.\%, that were effective against $S$. aureus and E. coli stains, while being cytocompatible in a rat calvaria osteoblast (RCO) cell line and promoting osteogenic differentiation [303]. However, contradictory cytotoxicity results were also published in the case of $\mathrm{Cu}$-doped HA. If the previous two presented cases indicated a good biocompatibility at doping levels of 2-5 at.\% [302,303], other researchers reported on the alarming cytotoxicity of 1 at.\% doped Cu-HA on to Balb/c 3T3 clone A3 mouse fibroblasts and on human foetal osteoblasts (hFOB 1.19) cell lines [238,301]. Moreover, Lima et al. [238] revealed a significant level of apoptosis when interacting with human monocytes (isolated from blood). Altogether, it is suggested that besides doping level, the synthesis technology as well as the testing cell line play prominent roles on the biological performance of $\mathrm{Cu}$ doped-HA.

Manganese $(\mathrm{Mn})$ is a trace ion in organism, being involved in several metabolic processes. As a doping element in HA, Mn can increase the bonding strength between HA film and metallic (Ti) implant substrate, while enhancing the corrosion resistance [194]. The Mn-HA possesses the ability to induce the nucleation and growth of biomimetic apatite layers in SBF [304-306]. Mn-HA stimulated cell viability and osteoblast proliferation, enhanced protein adsorption on the coating surface, thereby, and overall improved the metallic implant biocompatibility [305,307,308]. Mn-HA showed no cytotoxicity in the studies performed by Huang et al. [305], Li et al. [308], and Zilm et al. [309].

Iron (Fe) takes part in various organism functions, including bone metabolism. Fe promotes apatite nucleation (as demonstrated by both in vitro assays in SBF [310] and in vivo tests in sheep models [311]), enhances osteoblast adhesion, division and proliferation, and induces osteogenic function [308,309,312]. Moreover, Fe-HA exhibited antimicrobial effects on S. aureus and E. coli, while being biocompatible with human osteosarcoma cells (SaOS2), and increasing cell viability without any signs of cytotoxicity [312]. Magnetic Fe-HA nanoparticles damaged HepG2 cancer cells through hyperthermia processes [313,314]. A significant and fast effect on murine colon cancer was achieved within two weeks of Fe-HA action [313]. Such materials showed good biocompatibility and little toxicity when injected subcutaneously [313]. However Lima et al., previously mentioned in the case of 
$\mathrm{Mg}-$, Bi- and $\mathrm{Cu}$-doped HAs, have shown that the 1 at.\% doped Fe-HA, induces, as in the case of the other dopants, a significant level of human monocyte cell apoptosis [238].

Titanium (Ti) is an excellent choice for biomedical applications mostly due to its biocompatibility (related to its surface passivation that produces a thin hermetic $\mathrm{TiO}_{2}$ layer) and high mechanical strength [315]. Besides its use for the fabrication of medical devices (in either pure or alloyed form), $\mathrm{Ti}^{4+}$ can be integrated as substitutional dopant in HA to enhance cells viability, proliferation and differentiation, along with the stimulation of the extra-cellular matrix mineralization [68,316]. The in vitro formation of biomimetic apatite layers on top of Ti-HA was evidenced by SBF testing irrespective of doping level (no pure HA control data were provided) [317,318]. The biological activity of Ti-HA coatings is dependent on the Ti substrate surface: a rough metallic substrate enhanced the production and mineralization of the bone matrix compared to a smoother one, therefore enhancing the osseointegration capability [316]. Ti-HA showed slight bactericidal effect against E. coli, especially when the system is UV irradiated [177]. An effective antibacterial capability is achieved at $\sim 13$ at.\% Ti, although this effect is accompanied also by a slightly cytotoxicity on human foetal osteoblast cells [301]. Doping HA with Ti was proved to be beneficial for the increase of protein adsorption [177] and improvement of the mechanical properties (i.e., bonding strength, hardness and elastic modulus [68,105]).

Chromium $(\mathrm{Cr})$ is a trace element in the human body that is essential to metabolize sugars and fats. Doping HA with $\mathrm{Cr}$ might be beneficial for biomedical applications, but the cytotoxicity of such materials needs to be properly assessed. In vitro studies performed on cervical cancer cells (HeLa) and mouse fibroblast cells indicated that in both cases $\mathrm{Cr}$-HA nanoparticles are cytocompatible up to a concentration of $800 \mu \mathrm{g} \mathrm{mL}^{-1}$ and for a duration of 24-48 h [319]. In terms of haemocompatibility, the use of a low content of $\mathrm{Cr}$ dopant ( $0.5 \mathrm{at} . \%)$ is compulsory, as the blood cells are highly susceptible to cytotoxic stimuli [319]. Tests performed on Drosophila melanogaster Meigen genes have shown that Cr-doped (1 at.\%) HA powders do not exhibit genotoxicity [320].

Cobalt (Co) is an important element in human body, being a constituent of vitamin B12. Co ion doping of HA enabled antimicrobial activity against S. aureus, Microcosus luteus, and Shigella flexneri, but no such effect was encountered against P. aeruginosa [321]. For a low doping level (i.e., 0.37 at.\%), Co-HA sustained the human osteosarcoma cell viability, proliferation and differentiation, endorsing both osteogenic and proangiogenic properties [322]. A case of cobalt-doped HA (1 at.\%) apoptosis on human blood monocytes was reported, despite the fact that it simultaneously enhanced the osteoblasts adhesion [238]. The in vivo tests on animal models (white female Wistar rats) indicated that Co-HA stimulates the osteogenesis inside mandibular defect, 6 months after implantation [323].

Tantalum (Ta) doping of HA was rarely explored [324,325]. Ta-HA was shown to increase human osteoblast cell proliferation, hinder charge storage ability, but at the same time induce the partial decomposition of HA into $\beta$ - and $\alpha$-tricalcium phosphate [324].

Nickel (Ni) was shown to possess a dose-dependent cytotoxicity, and was tentatively advanced for biomedical applications [326,327]. When incorporated in HA, Ni had a positive effect on human osteosarcoma MG63 cell viability, proliferation and differentiation, with the adhered cells embedded into the bone matrix. Specifically, Ni-HA with low doping concentration $(\leq 2.4$ at. $\% \mathrm{Ni})$ is osteoconductive and proangiogenic [328]. Moreover, when used as a substitution co-dopant (together with $\mathrm{Mg}^{2+}$ and $\left.\left(\mathrm{SiO}_{4}\right)^{4-}\right), \mathrm{Ni}^{2+}$ enhanced the antibacterial effect against $E$. coli and P. aeruginosa [329].

Molybdenum (Mo) can be used as well as a doping cation in HA. The only paper found in this regard emphasized that Mo-HA nanorods can be used as antimicrobial agents in bone cement engineering, due to their bactericidal (S. epidermidis and E. coli) and anti-fungal (C. albicans) properties [330]. However, prior to being further recommended as a bone cement component, Mo-HA cytocompatibility should be assessed as well.

Yttrium (Y) is a d-block element that improves HA biocompatibility in human osteoblasts cell cultures [331,332]. Moreover, Y-HA was used as therapeutic agent for radioactive synovectomy in haemophilic synovitis [333]. 
Cadmium (Cd), although renowned for its toxicity, was tested as doping cation in HA to explore its action mechanisms. As the Cd content increased, the levels of DNA damage were substantially augmented in the liver of zebra fish, eventually causing death [334]. Cd-HA had also a detrimental effect on the growth of plants [335].

Tungsten (W) doped HA has great catalytic activity. W-HA enhanced the biosorption and adsorption of methyl orange by E. faecalis, having massive decolourization as a consequence [336]. This W-HA feature can be used in wastewater decontamination.

Hafnium (Hf) shows a great potential for oncological applications. Its high electron density and photo-luminescent properties make it a good candidate for photodynamic therapy $[337,338]$. In this respect, Hf-doped HA was tested in vitro on A549 human adenocarcinoma and in vivo in mice with lung cancer [339]. In vivo studies showed that when Hf-HA nanoparticles (NPs) are bombarded with ionizing radiation, the mice tumour growth was inhibited due to cell apoptosis. In vitro studies revealed also a high cytotoxicity towards human adenocarcinoma due to the formation of reactive oxygen species, while Hf-HA NPs interacted with ionizing radiation [339].

\section{4. f-Block Cation-Substituted Hydroxyapatites}

Recently, rare-earth metals (REM) (e.g., lanthanides and scandium) and actinides have attracted great interest in the orthopaedic field due to their high biological activity and ability to replace calcium ions in HAs [1,126,340]. Different lanthanide and actinide doping in HA have been attempted, such as lanthanum $\left(\mathrm{La}^{3+}\right)[267,340-343]$, cerium $\left(\mathrm{Ce}^{3+}\right)$ [344-349], praseodymium $\left(\operatorname{Pr}^{3+}\right)[345,350,351]$, neodymium $\left(\mathrm{Nd}^{3+}\right)[128,345,352,353]$, samarium $\left(\mathrm{Sm}^{3+}\right)$ [354-359], europium $\left(\mathrm{Eu}^{3+}\right)$ [353,360-367], gadolinium $\left(\mathrm{Gd}^{3+}\right)[128,354,368]$, terbium $\left(\mathrm{Tb}^{3+}\right)[345,353,361,369,370]$, holmium $\left(\mathrm{Ho}^{3+}\right)[371]$, erbium $\left(\mathrm{Er}^{3+}\right)[353,372]$, thulium $\left(\mathrm{Tm}^{3+}\right)[360]$, ytterbium $\left(\mathrm{Y}^{3+}\right)$ [373], and uranium $\left(\mathrm{U}^{3+}\right)[374,375]$.

The incorporation of lanthanides and actinides ions into HA is of significant interest for biomedical applications due to their excellent affinity for $\mathrm{Ca}^{2+}$ sites. In particular, for trivalent lanthanides this strong affinity is explained by an ion-exchange mechanism; the binding constant for the exchange increases as the ion size decreases [376]. When trivalent cations substitute $\mathrm{Ca}^{2+}$ ions, the charge imbalance is compensated for by either the generation of vacant cation sites or a loss of a proton from $(\mathrm{OH})^{-}$, and the ion-exchange ability depends strongly on the fluctuation of charge density induced by the adaptation of the lattice parameters $[50,376]$. The charge density increases as the lanthanides ion size decreases [376]. The lanthanides are well-suited elements for cationic substitution due to their similarities in ionic radii with $\mathrm{Ca}^{2+}$, donor atom requirements and coordination polyhedron geometries [376]. After substitution with REMs, a general decrease of crystallinity and increase of surface area was observed for doped HAs with respect to the pure phase $[5,377]$. REM or actinides-HA composites exhibited exceptional luminescence properties and are promising for application in biological fluorescence labelling (e.g., magnetic resonance imaging, multi-imaging diagnosis on single photon emission computed tomography (SPECT)). Their fluorescence is characterized by narrow emission bandwidths, high photochemical stability and long fluorescence lifetimes [1,126]. However, the exploration of the biological response of such doped HA materials is still in its infancy. In particular, the cytotoxicity effects are still open questions. The authors of this review advocate for the necessity of clarifications in this respect.

Lanthanum (La) doping can improve various physico-chemical properties of HA such as the thermal stability, resistance in acidic and physiological media, or inhibition of bone resorption [340,378]. Mechanical properties, such as tensile strength or micro-hardness, have been found to be enhanced with the increase of $\mathrm{La}^{3+}$ content in HA [340,379]. Also the addition of La ions improved the cell response and the antibacterial efficiency [378]. Joshy et al. observed in La-doped HA, prepared by the sol-gel technique, an antibacterial activity against Gram-positive (S. aureus and Bacillus) and Gram-negative (E. coli and Pseudomonas) [379]. Lou et al. prepared by a wet-chemical method La-doped HA with a doping atomic concentration up to $30 \%$, and further used it to fabricate implant coatings on Ti substrates by dip-coating [340]. No phase decomposition was observed. Their results indicated 
good bonding strength at the coating-substrate interface, accompanied by good angiogenesis and cytocompatibility in mouse calvaria MC3T3-E1 cell cultures (for La concentrations below 20 at.\%) [340]. Excellent biocompatibility was also observed in La-doped HA powder with similar doping range for a mouse L929 fibroblast cell line [342]. However, Jadalannagari et al. reported a cytotoxicity of $40 \%$ for adenocarcinoma MCF-7 cell cultures exposed for $72 \mathrm{~h}$ to La-doped (10 at.\%) HA at doses in the range of $5-100 \mu \mathrm{g} / \mathrm{mL}$ [380]. For similar La-HA powder/cell media ratios, no cytotoxicity against human embryonic kidney (HEK) and MCF-7 cell lines was observed in the case of La-doped (2 at.\%) HA. The viability was $\sim 87 \%$ after $72 \mathrm{~h}$ of cell culturing [380]. Thereby, promising prospects of La-HA use in biomedical applications could emerge in the near future.

Cerium (Ce) cation is characterized by an ionic radius and electronegativity similar to $\mathrm{Ca}^{2+}$. $\mathrm{Ce}$ can easily substitute calcium, accumulate in small quantities in bones, and boost the bone metabolism and the biomimetic HA-forming ability [1,344,381]. Moreover, Ce participates in the prevention of dental cavities, reduction of enamel demineralisation, acts as an antioxidant, and provides high thermal-phase stability [344,381,382]. In vitro biomimetic apatite formation, after being soaking in SBF for periods of 2-3 weeks has been noticed for Ce-HA materials $[383,384]$. Ce can also stimulate the antimicrobial activity, pathogen inhibition and regenerative properties [344,377,381,382]. Both $\mathrm{Ce}^{4+}$ and $\mathrm{Ce}^{3+}$ cations are present in Ce-substituted HAs, but in proportions dependent on experimental procedure [348,349, 385]. Various studies have reported the antibacterial properties of Ce-doped HA for Gram-positive (e.g., S. aureus [344,348,377,381,382,385], Lactobacillus [377], and B. subtilis [348]) and Gram-negative (e.g., E. coli $[348,377,381,382,385])$ strains. However, discrepancies exist in the reported Ce content able to induce an antibacterial effect. For example, Lin et al. synthesized by the sol-gel supercritical fluid drying method Ce-HA materials with a $[\mathrm{Ce} /(\mathrm{Ce}+\mathrm{Ca}) \cdot 100]$ atomic proportion ranging from 0 to 20 at.\%. They obtained improved antibacterial properties against E. coli, S. aureus, and Lactobacillus when adding Ce-doped ( $>8$ at.\%) HA NPs in concentrations of $100 \mathrm{mg} / \mathrm{mL}$ Ce-HA nanoparticles [377]. However, no indications of these materials' cytocompatibility were provided. The antibacterial activity for such high Ce doping levels was also confirmed by Sundarabharathi et al. [344] against P. aeruginosa and S. aureus, for sol-gel prepared Ce-doped (10 at.\%) HA, and G. Ciobanu et al. [385], against E. coli and S. aureus, for co-precipitation synthesized Ce-doped (10, 20 and 25 at.\%) HA. However, some studies report antibacterial activity below 8 at.\% Ce doping levels, specifically in the range for $0.3-1.25$ at. $\%$, for both co-precipitation [382] and sol-gel [348,381] Ce-doped HAs. Since Gram-negative bacteria have a less complex and thinner cell wall, it is expected that they are more sensitive to antibiotics than Gram-positive bacteria [348]. Although most studies agree on an enhanced inhibition zone for Gram-negative bacteria than for Gram-positive ones [348,381,382,385], discrepancies have been observed by Lin et al. [377] for S. aureus vs. E. coli, Sundarabharathi et al. [344] for S. aureus vs. P. aeruginosa, and Priyadarshini et al. for S. aureus vs. E. coli and P. aeruginosa or B. subtilis vs. E. coli and $P$. aeruginosa [348]. The antibacterial effect was found to increase with Ce content, if adding also $\mathrm{Fe}_{3} \mathrm{O}_{4}$ nanoparticles [381] or Sr ions [344].

On the basis of these studies it is possible to conclude that Ce induces significant antibacterial properties to HA for a wide concentration range (i.e., 1.25-25 at.\%), without the formation of secondary / residual phases. The mechanism of interaction between bacteria and Ce-HA colloidal solution was described by the release of Ce cations which penetrate the negatively charged surface of the microorganism cell membrane, inhibiting the DNA replication [348]. Concerning the biocompatibility, high concentrations of $\mathrm{Ce}^{3+}$ cations are cytotoxic [344]. MTT assays supported by inverted microscopy images indicated a good biocompatibility in human osteosarcoma MG-63 osteoblast cells exposed to concentrations of Ce-doped (1.25 at.\%) HA-NPs situated between 200-600 $\mu \mathrm{g} / \mathrm{mL}$, after 24 and $48 \mathrm{~h}$ incubation [348]. Cytotoxicity was encountered only for Ce-HA-NPs concentrations in the range of $800-1000 \mu \mathrm{g} \mathrm{mL}{ }^{-1}$ [348]. Also, although a slight decrease in cell viability was observed in comparison to the control, the CCK-8 assay indicated no significant cytotoxicity against mouse L929 fibroblast cells, when a Ce-doped ( 5 at.\%) HA powder prepared by co-precipitation was added to the medium at doses lower than $100 \mu \mathrm{g} \mathrm{mL}{ }^{-1}$ [386]. Slight cytotoxicity was observed for doses of 200 and $500 \mu \mathrm{g} \mathrm{mL}^{-1}$ [386]. In contrast, in vitro cytotoxicity assessed by MTT against human lung A549 cells exposed to Ce-doped 
(10 at.\%) HA-NPs concentrations of $100 \mu \mathrm{g} \mathrm{mL}{ }^{-1}$ showed a significant decrease in cell viability [344]. Interestingly, Ce-doped ( 9 at.\%) HA coatings, deposited on titanium substrates by DC pulse micro-arc oxidation, exhibited a good biocompatibility in mouse skull MC3T3-E1 cell cultures at $48 \mathrm{~h}$ [346]. It is worth noting that the cytotoxicity of Ce could be alleviated by adding $\mathrm{Sr}$ as co-dopant $[344,387]$. Biocompatible Ce-HA could also find applications as a fluorescent probe for cellular imaging or as an antioxidant agent.

Praseodymium (Pr) doping in HA was shown to be suitable for applications in radiotherapy [350,351]. Samarium (Sm) is another important REM element for biomedical applications, being a good candidate for cancer radiation therapies and bone pain treatment [1,357]. Furthermore, Sm is able to change the permeability of cell membranes and can be used in the treatment of synovitis [357]. Ciobanu et al. reported the synthesis of Sm-doped (0.2-0.5 at.\%) HA powder by co-precipitation and studied the influence of Sm concentration on the antibacterial activity against Gram-positive (E. faecalis and S. aureus) and Gram-negative (P. aeruginosa and E. coli) strains. The antimicrobial activity for Gram-positive and Gram-negative bacteria was obtained at Sm contents of 0.2 and 0.5 at.\%, respectively, for Sm-HA-NPs doses in the range of $0.125-1 \mathrm{mg} \mathrm{mL}^{-1}$ [355]. An antifungal effect against C. albicans ATCC 10231 strain was also observed by colony-forming unit count (CFU) assay and confocal laser scanning microscopy (CLSM) images of live/dead fungus [357]. Sm-HA exhibited an excellent biocompatibility (in terms of cell viability and proliferation) in human foetal osteoblast cell (HFOB 1.19) cultures for doping levels up to at 5 at.\% [355]. The results revealed that the Sm-HA powder is a good candidate to treat wounds and prosthetic joint infection. The enhancement of the osteoblastic performance, cell viability and antibacterial activity was also demonstrated by Sathishkumar et al. [354], when Sm was present in HA as co-doping along with Gd.

Europium (Eu), like Ce, is present in the human body, in small amounts, in the bones and liver [1]. $\mathrm{Eu}$ is an interesting element for the treatment of osteoporosis [365] and for promoting bone remodelling cycle [366]. Eu is easily incorporated in the HA crystal lattice due to their similar ionic radius. Eu-HA induces the in vitro formation of bone-like apatite in SBF [388]. Eu-doped HA (0.1-2 at.\%) showed good antibacterial activity against Gram-positive E. faecalis and Gram-negative P. aeruginosa, at powder doses of 31-1000 $\mu \mathrm{g} \mathrm{mL}^{-1}$ and $125-1000 \mu \mathrm{g} \mathrm{mL}{ }^{-1}$, respectively [362,389]. The antibacterial action against Gram-positive S. aureus strain has been demonstrated at powder doses of $31-1000 \mu \mathrm{g} \mathrm{mL}^{-1}$ [389]. No antibacterial activity was found for Gram-negative E. coli even at low concentration of $\mathrm{Eu}^{3+}$. Furthermore, at 2 at.\% of Eu, Iconaru et al. [389] observed a good fungicidal activity against C. albicans. Various studies have shown the excellent biocompatibility of Eu-doped HA. Frumosu et al. [363] synthesized Eu-doped (0.5 and 1.5 at.\%) HA by co-precipitation and observed for up to 4 days the cell proliferation of osteosarcoma MG-63 cells. $\mathrm{Ca}_{10-\mathrm{x}} \mathrm{Eu}_{\mathrm{x}}\left(\mathrm{PO}_{4}\right)_{6}(\mathrm{OH})_{2}$ bioceramics (with $\mathrm{x}=0.01-$ 0.2) prepared by co-precipitation enabled the excellent proliferation of human embryonic kidney (HEK 293) cells, with no sign of cytotoxicity after 24 and 48 h [365,390]. Eu-doped (5 at.\%) HA NPs, used in doses of $0.3-30 \mu \mathrm{g} / \mathrm{mL}$ was not found compatible with transformed human umbilical vein endothelial cells (T-HUVEC) [391]. In vitro tests with L929 mouse fibroblasts and ex ovo tests using aqueous injection into vitelline vein of chicken egg, were performed by Tesch et al. [392] for Eu-doped (10 at.\%) HA at doses of $25-500 \mu \mathrm{g} \mathrm{mL} \mathrm{m}^{-1}$ and $500 \mu \mathrm{g} \mathrm{mL}-1$, respectively. Their results indicated a cell viability of more than $80 \%$ after $24 \mathrm{~h}$ incubation and no toxicity (i.e., thrombosis and vascular lysis) [392]. Zheng et al. [393] indicated that Eu-doped (15 at.\%) HA nanorods, prepared by the hydrothermal route, have excellent biocompatibility with pulmonary adenocarcinoma A549 and HeLa cells (i.e., viability of more than $100 \%$ after being exposed for $24 \mathrm{~h}$ at Eu-HA doses of $20-320 \mu \mathrm{gL} \mathrm{m}^{-1}$ ). Miranda-Melendez et al. [364] showed a low or absent cytotoxicity at $24 \mathrm{~h}$, for Eu-HA materials synthesized by wet-chemical precipitation, when cultivating human gingival fibroblast (HGF-1) cell cultures with doses of 500-2000 $\mu \mathrm{g} \mathrm{mL}^{-1}$ of HA having Eu doping contents up to 20 at. $\%$. After $48 \mathrm{~h}$ incubation, the best Eu-HA biological performance was met for the 5 at.\% doping. Amazingly, a low toxicity (i.e., HeLa cell viability of more than to $80 \%$ ) was revealed for HA NPs with large contents of $\mathrm{Eu}\left(\sim 9-17\right.$ at.\%) used at high doses $\left(10,000-30,000 \mu \mathrm{g} \mathrm{mL}^{-1}\right)$ [366]. However, when coupled with 5 
fluorouracil (5FU), a drug used for cancer treatment, Eu-HA shown the potential to kill HeLa cells, indicating the applicability of such composites as theranostic agents [364,366].

Terbium $(\mathrm{Tb})$ has attracted extensive attention due to its multiple potential application in biomedical field when combined with $\mathrm{HA}, \mathrm{Tb}$ being one of the most luminescent rare-earth biological probes due to its excellent emission feature with a main signal at $544 \mathrm{~nm}$ [209,394-397]. Furthermore, $\mathrm{Tb}$ exhibits excellent photocatalytic [394] and gene delivery [370] properties, as well as potential bactericidal activity and an ability to inhibit cancer cell development [398]. However, Tb is harmful for the human body at high concentrations [398]. CLSM images indicated that Tb-doped (2 at.\%) HA samples, prepared by co-precipitation, showed a good biocompatibility with transformed T-HUVEC [361]. Wei et al. [399] synthesized Tb-doped ( 17 at.\%) HA nanorods by hydrothermal method, and showed via optical density analysis using Counting Kit-8 assay, an excellent MC3T3-E1 cells viability when exposed to Tb-HA concentrations of $25-100 \mu \mathrm{g} \mathrm{mL}-1$ over a period of 7 days. The results were further confirmed by the unaltered morphology of the luminescent cells. The lack of in vivo toxicity in animal model of Tb-HA nanorods was also emphasized by the histological analysis of various organs of rats [399]. Zheng et al. [393] indicated that Tb-doped (15 at.\%) HA nanorods, prepared by the hydrothermal route, have good biocompatibility with pulmonary adenocarcinoma A549 cells after being exposed for $24 \mathrm{~h}$ to colloidal concentrations between $20-320 \mu \mathrm{g} \mathrm{mL}{ }^{-1}$. Their results have been also confirmed by CLSM analysis.

Gadolinium (Gd), dysprosium (Dy), and neodymium (Nd)-substituted HA composites have been widely used for such a purpose in magnetic resonance imaging (MRI) [392,400]. It is worth mentioning also that paramagnetic elements play an important role in multimodal imaging as contrast agents [392]. $\mathrm{Gd}^{3+}$ and $\mathrm{Nd}^{3+}$ have been also used as theranostic NPs for early stage diagnosis of cancer by near-infrared fluorescence techniques [352,368]. The thermo-luminescence properties of Gd-HA could also be used in gamma radiation dosimetry applications [401]. However, few studies concerning their biological activity were reported to date.

Li et al. [128] synthesized nanocrystalline Gd-HA and Nd-HA with different doping levels (1, 4.8, 9, and 17 at.\%) and observed a de-hydroxylation of HA without significant changes in the lattice parameters. The doped-HA samples showed a significant increase of the electrical conductivity in comparison to pure HA which is important for the electromagnetic sector and for the acceleration of bone fracture healing [128]. The agar diffusion method and live/dead cell assays indicated that all but one Gd-HA samples (i.e., 17 at.\% Gd-doped HA) studied by Li et al. [128] were not cytotoxic for human foetal osteoblast (hFOB 1.19) cells at $24 \mathrm{~h} ; 9$ at.\% Gd was the optimum concentration showing good biocompatibility. Li et al. [128] mentioned that the presence of non-coordinated or free $\mathrm{Gd}^{3+}$ cations could explain the toxicity of the 17 at.\% Gd-doped HA, but more insightful biocompatibility tests are required, since the deleterious role of secondary $\mathrm{Gd}_{2} \mathrm{O}_{3}$ phase and possible $\mathrm{Gd}(\mathrm{OH})_{3}$ moisture cannot be excluded. Laranjeira et al. [402] synthesized Gd-doped (2.5-9 at.\%) HA by the co-precipitation method and showed no in vitro cytotoxicity effect on human dermal microvascular endothelial cells (hDMECs) at any of the Gd doping concentrations. The morphology of the cells was not affected. Furthermore, the Gd-HA samples dosed to a concentration up to $4000 \mu \mathrm{g} \mathrm{mL}^{-1}$ were haemocompatible, non-haemolytic and non-thrombogenic, which is a crucial for magnetic resonance imaging (MRI) applications. Important to note, Laranjeira et al. [402] reported no phase separation or the advent of metallic oxides $/ \mathrm{Gd}(\mathrm{OH})_{3}$.

Victor et al. [352] studied the biocompatibility at $24 \mathrm{~h}$ of the Nd-doped (at.\% 11) HA NPs on L929 fibroblast cell line, by MTT and Live/dead cell assays, using doses of 10,000 and 20,000 $\mu \mathrm{g} \mathrm{mL}^{-1}$. A cell viability of more than $90 \%$, with negligible influence on their proliferation, was observed [352]. The increased uptake by HeLa cells of Nd-HA containing alginic acid-4-acetyl salicylic acid nano-platforms, from 4 to $16 \mathrm{~h}$, was confirmed by Raman microscopic imaging, which indicated a growing cluster size and localization in the cytoplasm. Victor et al. [352] showed also that Nd-doped HA are able to deliver with great specificity anticancer drugs and simultaneously allow for fluorescence imaging, which would be an important advance in cancer therapy. 
Lafarga et al. [403] evaluated in vivo on an animal model (rats) the toxicity of Dy-substituted (5 at.\%) HA, synthesized by co-precipitation, and observed an increase of the oxidative stress indicators (i.e., lipoperoxides, nitric oxide) in the kidneys, lungs and liver, as well as a lower activity of the anti-oxidant enzyme (i.e., glutathione peroxidase). However, no significant change was observed in the membrane fluidity and adenosine triphosphate (ATP) activity. By functionalizing the HA nanoparticles with folic or glucuronic acid the toxicity could be significantly diminished. A MTT test with L929 mouse fibroblasts and aqueous HA injection into vitelline vein of egg indicated no toxicity of Dy-doped (10 at.\%) HA used in doses of $25-500 \mu \mathrm{g} \mathrm{mL}^{-1}$ [392]. However, in this study performed by Tesch et al. [392] the real amount of Dy-doping evaluated by inductively coupled plasma mass spectrometry (ICP-MS) was approximatively half of the quantity theoretically inserted during the synthesis.

Erbium (Er) is a promising REM element due to its light emission and enhancement of biological properties of HA [372,404]. A strong and stable near-infrared emission at $1540 \mathrm{~nm}$, compatible with telecommunication applications, has been observed in Er-doped ( 4.4 at.\%) HA synthesized by co-precipitation [404]. Alshemary et al. [372] studied the in vitro bioactivity of Er-doped (2-10 at.\%) HA fabricated by microwave-assisted precipitation from SBF solution, and showed the formation of a biomimetic apatite layer after $24 \mathrm{~h}$ of immersion.

Uranium (U)-doped HA with doping levels up to 10 at.\%, remarkably did not alter MC3T3-E1 osteoblast viability and proliferation [375]. Further studies are necessary to understand the lack of toxicity when such an exogenous actinide metal is introduced in a controlled but large quantity into HA.

The nature of our exhaustive review of the literature allowed us to devise Table 3, which now encompasses, for the first time, the plethora of doping possibilities able to expand the biofunctional response of HA, with an emphasis on the role and the impact of each cation-doping species.

Table 3. Synopsis of the bio-functionality realm of cation-substituted hydroxyapatites.

\begin{tabular}{|c|c|c|c|c|c|}
\hline $\begin{array}{l}\text { Cation } \\
\text { (M) }\end{array}$ & $\begin{array}{l}\text { Sample } \\
\text { Form }\end{array}$ & $\begin{array}{l}\text { Doping Range } \\
{[\mathrm{M} /(\mathrm{M}+\mathrm{Ca})]} \\
100(\text { at. } \%)\end{array}$ & & Bio-Functionality/Effect of the Dopant & Refs. \\
\hline $\mathbf{L i}$ & $\begin{array}{l}\text { Powder } \\
\text { Scaffold } \\
\text { Coating }\end{array}$ & $0.5-2$ & $\begin{array}{l}0 \\
0\end{array}$ & $\begin{array}{l}\text { Stimulates in vitro bone-like apatite growth in } \\
\text { simulated body fluid (SBF); } \\
\text { In vitro cytocompatibility with bone marrow } \\
\text { mesenchymal stem cells (BMMSCs), calvaria isolated } \\
\text { osteoblasts, human osteosarcoma (MG63) cell lines; } \\
\text { Increases cell viability and proliferation; } \\
\text { Li-HA scaffolds revealed in vivo (Japanese white } \\
\text { rabbits) good osteogenesis and } \\
\text { angiogenesis potential; } \\
\text { Improves the compressive mechanical strength; } \\
\text { Induces the new bone formation in animal model. }\end{array}$ & {$[98,221-224]$} \\
\hline $\mathrm{Na}$ & $\begin{array}{l}\text { Powder } \\
\text { Coating }\end{array}$ & 5 & $\begin{array}{l}0 \\
0\end{array}$ & $\begin{array}{l}\text { Enhances the in vitro biomineralization of apatite } \\
\text { in SBF; } \\
\text { In vitro cytocompatibility with mouse skull } \\
\text { osteoblastic cell (MC3T3-E1) lines; } \\
\text { Promotes osteoblast proliferation; } \\
\text { Increases coating adhesion on reinforced } \\
\text { carbon fibres; } \\
\text { Stimulates dense new bone formation in } \\
\text { animal model. }\end{array}$ & {$[227,229]$} \\
\hline $\mathbf{K}$ & Powder & $2.5-47$ & $\bigcirc$ & $\begin{array}{l}\text { The adsorption of bovine serum albumin increases } \\
\text { with dopant concentration; } \\
\text { Constitutes a potential needle-free protein/antigen } \\
\text { trans-dermal delivery system. }\end{array}$ & {$[232,233]$} \\
\hline
\end{tabular}


Table 3. Cont

\begin{tabular}{|c|c|c|c|c|c|}
\hline $\begin{array}{l}\text { Cation } \\
\text { (M) }\end{array}$ & $\begin{array}{l}\text { Sample } \\
\text { Form }\end{array}$ & $\begin{array}{l}\text { Doping Range } \\
{[\mathrm{M} /(\mathrm{M}+\mathrm{Ca})]} \\
100(\text { at. } \%)\end{array}$ & & Bio-Functionality/Effect of the Dopant & Refs. \\
\hline Mg & $\begin{array}{l}\text { Powder } \\
\text { Coating }\end{array}$ & $1-53$ & $\begin{array}{l}0 \\
0 \\
0 \\
0\end{array}$ & $\begin{array}{l}\text { Mg doping stimulates bone-like apatite growth } \\
\text { in SBF; } \\
\text { In vitro cytocompatibility with MC3T3-E1, MG63, } \\
\text { primary rat osteoblasts (rOBs) and endothelial cells } \\
(r E C s) ; \\
\text { Improves the adhesion and stimulates the } \\
\text { proliferation and differentiation of osteoblasts; } \\
\text { Mg ( 1 at.\%) induces apoptosis of human } \\
\text { monocytes; } \\
\text { Antibacterial effect against S. aureus (ATCC 29213), } \\
\text { E. coli (ATCC } 25922) \text {, and P. aeruginosa (ATCC } 27853 \text { ); } \\
\text { Enhances osteoconductivity as demonstrated } \\
\text { in vivo on animal model. }\end{array}$ & $\begin{array}{c}{[235-240,242,} \\
243]\end{array}$ \\
\hline Sr & $\begin{array}{l}\text { Powder } \\
\text { Coating }\end{array}$ & $1-40$ & 0 & $\begin{array}{l}\text { Improves the biomineralization capacity (both in } \\
\text { SBF and modified Eagle's medium (MEM) media); } \\
\text { In vitro cytocompatibility with MG63, human foetal } \\
\text { bone-cloned osteoblast (OPC1), MC3T3-E1, human } \\
\text { osteoblast (hFOB 1.19) cell lines; } \\
\text { Enhances the osteoblast cells proliferation and } \\
\text { differentiation (enabling new bone formation); } \\
\text { Inhibits osteoclast production and proliferation } \\
\text { (reducing bone resorption); } \\
\text { Enhances new bone formation. }\end{array}$ & $\begin{array}{l}{[240,243-246,} \\
249-252,255 \\
257]\end{array}$ \\
\hline Ba & Powder & $0.5-2$ & 0 & $\begin{array}{l}\text { Increases the biomineralization capacity of CaPs } \\
\text { in SBF. } \\
\text { No information on in vitro or } \\
\text { in vivo biocompatibility; } \\
\text { Does not inhibit the proliferation of pathogens } \\
\text { such as: S. aureus (COWAN 1), Bacillus megaterium } \\
\text { (DMS 32), E. coli (ATCC 259225), K. pneumonia (FMC } \\
\text { 5), and C. albicans (FMC 17). }\end{array}$ & {$[261,262]$} \\
\hline Al & Powder & $0.5-2.5$ & 0 & $\begin{array}{l}\text { In vitro cytocompatibility with mouse fibroblast cell } \\
\text { (L929) line. }\end{array}$ & [263] \\
\hline $\mathrm{Ga}$ & Powder & $\mathrm{n} / \mathrm{a}$ & 0 & $\begin{array}{l}\text { In vitro cytocompatibility with murine cells } \\
\text { (RAW264.7); } \\
\text { Antibacterial effect against P. aeruginosa (MW1); } \\
\text { Non-effective against E. coli and S. epidermidis. }\end{array}$ & {$[264,266]$} \\
\hline In & Powder & $1 ; 3$ & $\bigcirc$ & $\begin{array}{l}\text { In vitro cytocompatibility with human limb tissue } \\
\text { osteoblast cells line (ATCC CRL-11372); } \\
\text { Improves the osteoblasts' adhesion and } \\
\text { differentiation; } \\
\text { Induces certain levels of blood monocyte apoptosis. }\end{array}$ & {$[238,267]$} \\
\hline $\mathbf{B i}$ & Powder & $5-25$ & $\begin{array}{l}0 \\
0 \\
0 \\
0 \\
0\end{array}$ & $\begin{array}{l}\text { Increases HA dissolution rate; } \\
\text { Induces the in vitro formation of bone-like apatite } \\
\text { in SBF; } \\
\text { In vitro cytocompatibility with human limb tissue } \\
\text { osteoblast cells from (ATCC CRL-11372); } \\
\text { Improves osteoblast adhesion and differentiation; } \\
\text { Bi-HA (scaffolds)_polyurethane (matrix) elicit } \\
\text { excellent mechanical, biocompatible and } \\
\text { osteoconductive properties in vivo (rabbits); } \\
\text { Antibacterial effect against S. aureus and E. coli; }\end{array}$ & [267-269] \\
\hline Te & Powder & $0.04-0.22$ & 0 & $\begin{array}{l}\text { Antimicrobial effect against } S \text {. aureus, Bacillus } \\
\text { subtilis, Micrococcus sp., P. aeruginosa, Klebseilla sp., } \\
\text { Proteus mirabilis, Shigella dysenteriae and C. albicans. }\end{array}$ & [272] \\
\hline
\end{tabular}


Table 3. Cont.

\begin{tabular}{|c|c|c|c|c|c|}
\hline $\begin{array}{l}\text { Cation } \\
\text { (M) }\end{array}$ & $\begin{array}{l}\text { Sample } \\
\text { Form }\end{array}$ & $\begin{array}{c}\text { Doping Range } \\
{[\mathrm{M} /(\mathrm{M}+\mathrm{Ca})] \cdot} \\
100(\text { at. } \%)\end{array}$ & & Bio-Functionality/Effect of the Dopant & Refs. \\
\hline Ag & $\begin{array}{l}\text { Powder } \\
\text { Scaffold } \\
\text { Coating }\end{array}$ & $0.5-5$ & $\begin{array}{l}0 \\
0 \\
0 \\
0 \\
0\end{array}$ & $\begin{array}{l}\text { Induces the in vitro biomineralization of biomimetic } \\
\text { apatite layers in both SBF and McCoy media; } \\
\text { In vitro cytocompatibility with L929 (at Ag } \\
\text { concentrations <3 at.\%), hFOB } 1.19 \text { (induces } \\
\text { premature apoptosis, delayed differentiation or cell } \\
\text { death at high Ag contents (>3 at.\%) [250], but at low } \\
\text { Ag concentrations ( } 0.5-2 \text { at.\%) sustains the cell } \\
\text { functions without interference [280]), human } \\
\text { embryonic palatal mesenchymal (HEPM) (Ag = } 2 \text { at.\%) } \\
\text { [273]) cell lines; } \\
\text { In vivo evaluations on Sprague-Dawley rats showed } \\
\text { efficiency against methicillin-resistant S. aureus } \\
\text { (MRSA) strains, while not producing argyria, or any } \\
\text { other kind of skin disorder or affecting the brain, } \\
\text { kidneys, liver or spleen of the animals [283]; } \\
\text { Antibacterial effect against: MRSA (UOEH6), S. } \\
\text { aureus (ATCC6538, Cowan I, 0364, ATCC 25293), S. } \\
\text { epidermidis (ATCC 35984), Enterococcus faecalis (ATCC } \\
\text { 29212), P. aeruginosa, Bacillus megaterium (DMS 32), E. } \\
\text { coli (ATCC25922, ATCC25923), Klebsiella pneumoniae } \\
\text { (ATCC4352, 2968, ESBL, FMC 5), Enterobacter cloacae } \\
\text { (61R), Providencia stuartii (1116), and Citrobacter } \\
\text { freundii (1748); } \\
\text { Antifungal effect against yeast strains: Candida } \\
\text { krusei (963) and C. albicans (FMC17); } \\
\text { Not effective as antibiotic against: Bacillus subtilis } \\
\text { [275] and Serratia marcescens (0804) [276]; } \\
\text { Ag }{ }^{+} \text {does not affect the densification of HA; } \\
\text { At low concentrations it decreases HA solubility; } \\
\text { Hardness is affected by Ag doping. }\end{array}$ & $\begin{array}{c}{[250,261,273,} \\
275-286]\end{array}$ \\
\hline $\mathrm{Zn}$ & $\begin{array}{l}\text { Powder } \\
\text { Coating }\end{array}$ & $0.1-50$ & $\begin{array}{l}0 \\
0 \\
0 \\
0\end{array}$ & $\begin{array}{l}\text { Excellent in vitro bioactivity in SBF; } \\
\text { In vitro cytocompatibility with MC3T3-E1, MG63, } \\
\text { mouse Balb/c 3T3 clone A3 fibroblast cell lines; } \\
\text { No inflammatory effect; } \\
\text { Positive effect on osteoblast cells viability, } \\
\text { adhesion, spreading, proliferation and } \\
\text { differentiation; stimulates osteogenic activity and } \\
\text { bone growth or healing; } \\
\text { Cytotoxic to human hepatocarcinoma (HepG2) cells at } \\
\text { concentrations <1 at.\%, function of } \\
\text { particle morphology; } \\
\text { Antibacterial effect activity against: S. aureus } \\
\text { (CECT } 976 \text {, ATCC 25923, ATCC } 43300 \text { ), MRSA, S. } \\
\text { epidermidis (ATCC 14990), Bacillus subtilis (ATCC } \\
\text { 6051), S. mutans (ATCC 25175), Lactobacillaceae, } \\
\text { Streptococcus sobrinus, E. coli (CECT 434, MG1655, } \\
\text { ATCC } 12435, \text { ATCC 25922), and Enterobacter } \\
\text { aerogenes (ATCC } 13048 \text { ); } \\
\text { Antifungal effect against C. albicans (ATCC 10231); } \\
\text { Enhances new bone formation as demonstrated } \\
\text { in vivo on animal model. }\end{array}$ & $\begin{array}{c}{[66,238,243,} \\
274,277,281, \\
282,287-289, \\
291-298]\end{array}$ \\
\hline
\end{tabular}


Table 3. Cont

\begin{tabular}{|c|c|c|c|c|c|}
\hline $\begin{array}{l}\text { Cation } \\
(\mathrm{M})\end{array}$ & $\begin{array}{l}\text { Sample } \\
\text { Form }\end{array}$ & $\begin{array}{c}\text { Doping Range } \\
{[\mathrm{M} /(\mathrm{M}+\mathrm{Ca})]} \\
100(\text { at. } \%)\end{array}$ & & Bio-Functionality/Effect of the Dopant & Refs. \\
\hline \multirow{7}{*}{$\mathrm{Cu}$} & \multirow{7}{*}{$\begin{array}{l}\text { Powder } \\
\text { Coating }\end{array}$} & \multirow{7}{*}{$0.04-5$} & $\mathrm{O}$ & Excellent in vitro bioactivity in SBF. & \multirow{7}{*}[238,299-303]{} \\
\hline & & & 0 & $\begin{array}{l}\text { Beneficial for inducing protein absorption, } \\
\text { osteogenic differentiation, bone-like apatite } \\
\text { nucleation and growth at implant site; }\end{array}$ & \\
\hline & & & 0 & $\begin{array}{l}\text { In vitro cytocompatibility with } M C 3 T 3-E 1 \text { and rat } \\
\text { calvarial osteoblast cell lines; }\end{array}$ & \\
\hline & & & O & $\begin{array}{l}\text { A doping concentration of } \mathbf{1} \text { at. } \% \text { is cytotoxic to } \\
\text { Balb/c 3T3 clone A3 mouse fibroblasts and to HFOB } \\
1.19 \text { cellular lines, reducing the cells viability; }\end{array}$ & \\
\hline & & & O & $\begin{array}{l}\text { A significant level of apoptosis is recorded for a } \\
\text { concentration of } \mathbf{1} \text { at.\% for the human monocytes } \\
\text { isolated from blood; }\end{array}$ & \\
\hline & & & O & $\begin{array}{l}\text { Antimicrobial effect against S. aureus (ATCC 25923) } \\
\text { and E. coli (ATCC 25922); }\end{array}$ & \\
\hline & & & 0 & Antifungal effect against C. albicans (ATCC 24433). & \\
\hline \multirow{4}{*}{ Mn } & \multirow{4}{*}{$\begin{array}{l}\text { Powder } \\
\text { Coating }\end{array}$} & \multirow{4}{*}{$0.4-20$} & $\mathrm{O}$ & $\begin{array}{l}\text { Possesses the ability to induce the in vitro growth on } \\
\text { biomimetic apatite in SBF; }\end{array}$ & \multirow{4}{*}{ [304-309] } \\
\hline & & & 0 & $\begin{array}{l}\text { In vitro cytocompatibility with } M C 3 T 3-E 1 \text { and } \\
\text { hFOB } 1.19 \text { cell lines; } \\
\text { Stimulates cell viability and proliferation, and } \\
\text { improves metallic implant biocompatibility; }\end{array}$ & \\
\hline & & & 0 & $\begin{array}{l}\text { Increases bonding strength between HA coating } \\
\text { and metallic (Ti) implant; }\end{array}$ & \\
\hline & & & $\bigcirc$ & Enhances the corrosion resistance. & \\
\hline \multirow{8}{*}{ Fe } & \multirow{8}{*}{ Powder } & \multirow{8}{*}{$1-50$} & $\mathrm{O}$ & $\begin{array}{l}\text { In vitro cytocompatibility with } M C 3 T 3-E 1, h F O B \\
1.19, M G 63 \text { cell lines; }\end{array}$ & \multirow{8}{*}{ [308-314] } \\
\hline & & & 0 & Increases osteoblasts adhesion and proliferation; & \\
\hline & & & 0 & $\mathrm{Fe}^{3+}$ is involved in osseointegration; & \\
\hline & & & 0 & Not cytotoxic for doping levels $<12$ at. $\%$; & \\
\hline & & & 0 & $\begin{array}{l}\text { Induces certain levels of human blood monocyte cells } \\
\text { apoptosis; }\end{array}$ & \\
\hline & & & O & $\begin{array}{l}\text { Fe-HA has a great potential as heating mediator in } \\
\text { hyperthermia therapy of cancer, showing a fast and } \\
\text { effective effect on hepatic and colon cancer; }\end{array}$ & \\
\hline & & & 0 & Antibacterial effect against $S$. aureus and E. coli; & \\
\hline & & & 0 & $\begin{array}{l}\text { Promotes bone-like apatite nucleation both } \\
\text { in vitro in SBF and in vivo in animal model. }\end{array}$ & \\
\hline \multirow{5}{*}{ Ti } & \multirow{5}{*}{$\begin{array}{l}\text { Powder } \\
\text { Coating }\end{array}$} & \multirow{5}{*}{$1-13$} & O & $\begin{array}{l}\text { Induces in vitro formation of biomimetic apatite } \\
\text { in SBF; }\end{array}$ & \multirow{5}{*}{$\begin{array}{c}{[68,177,301,} \\
316-318]\end{array}$} \\
\hline & & & O & $\begin{array}{l}\text { In vitro cytocompatibility with rat bone marrow } \\
\text { stromal, HFOB } 1.19 \text { (up to 13 at.\%), and MG63 } \\
\text { cell lines; }\end{array}$ & \\
\hline & & & 0 & $\begin{array}{l}\text { Enhances cell proliferation, differentiation in } \\
\text { osteoblasts and matrix mineralization; }\end{array}$ & \\
\hline & & & 0 & Antibacterial effect against E. coli (IFO 3310); & \\
\hline & & & O & $\begin{array}{l}\text { Hardness and elastic modulus increases with } \\
\text { Ti addition. }\end{array}$ & \\
\hline \multirow{3}{*}{$\mathrm{Cr}$} & \multirow{3}{*}{ Powder } & \multirow{3}{*}{$0.5-2.5$} & $\mathrm{O}$ & $\begin{array}{l}\text { In vitro cytocompatibility with } L 929 \text { and cervical } \\
\text { cancer }(\mathrm{HeLa} \text { ) cell lines up to a concentration of } 800 \\
\mu \mathrm{g} \mathrm{mL} \mathrm{m}^{-1}\end{array}$ & \multirow{3}{*}[319,320]{} \\
\hline & & & 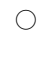 & $\begin{array}{l}\text { In vitro haemocompatibility in the case of low } \\
\text { doping concentrations }(\sim 0.5 \text { at. } \%) \text {; }\end{array}$ & \\
\hline & & & 0 & $\begin{array}{l}\text { Cr-HA does not exhibit mutagenicity on Drosophila } \\
\text { melanogaster Meigen larvae. }\end{array}$ & \\
\hline
\end{tabular}


Table 3. Cont

\begin{tabular}{|c|c|c|c|c|c|}
\hline $\begin{array}{l}\text { Cation } \\
\text { (M) }\end{array}$ & $\begin{array}{l}\text { Sample } \\
\text { Form }\end{array}$ & $\begin{array}{l}\text { Doping Range } \\
{[\mathrm{M} /(\mathrm{M}+\mathrm{Ca})]} \\
100(\text { at. } \%)\end{array}$ & & Bio-Functionality/Effect of the Dopant & Refs. \\
\hline Co & Powder & $0.2-27$ & $\begin{array}{l}\bigcirc \\
0 \\
0\end{array}$ & $\begin{array}{l}\text { In vitro cytocompatibility with MG63 cell line; } \\
\text { Elicits proangiogenic and osteogenic properties; } \\
\text { No haemolytic effect for doping levels up to } 37 \\
\text { at.\%; } \\
\text { Might induce human blood monocyte cells apoptosis; } \\
\text { Antibacterial effect against } S \text {. aureus, M. luteus, and } \\
\text { S. flexneri; } \\
\text { Ineffective against P. aeruginosa bacterial stain; } \\
\text { Stimulates the osteogenesis as demonstrated by } \\
\text { in vivo tests on animal model. }\end{array}$ & {$[238,321-323]$} \\
\hline Ta & Powder & $0.13-0.27$ & $\begin{array}{l}0 \\
0\end{array}$ & $\begin{array}{l}\text { In vitro cytocompatibility with } h F O B \text { cell line; } \\
\text { Promotes osteoblast proliferation. }\end{array}$ & [324] \\
\hline $\mathrm{Ni}$ & Powder & $\begin{array}{c}0.8-8.3 \\
\text { (theoretical) } 0.2- \\
2.4(\text { determined } \\
\text { by ICP-OES) }\end{array}$ & $\begin{array}{l}0 \\
0 \\
0\end{array}$ & $\begin{array}{l}\text { In vitro cytocompatibility with MG63 cell line; } \\
\text { Increases osteoblasts viability, proliferation and } \\
\text { differentiation; } \\
\text { Antibacterial effect against } E \text {. coli (ATCC 25922) } \\
\text { and P. aeruginosa (DSM50071), when tested in } \\
\text { combination with other dopants. }\end{array}$ & {$[328,329]$} \\
\hline Mo & Powder & $0.05-5.2$ & $\begin{array}{l}\bigcirc \\
\bigcirc \\
0\end{array}$ & $\begin{array}{l}\text { Antibacterial effect against } S \text {. epidermidis and E. coli; } \\
\text { Antifungal effect against } C \text {. albicans; } \\
\text { Enhances HA's ability to absorb the } \\
\text { electromagnetic gamma radiation. }\end{array}$ & [330] \\
\hline $\mathbf{Y}$ & $\begin{array}{l}\text { Powder } \\
\text { Coating }\end{array}$ & $1.3-7$ & 0 & $\begin{array}{l}\text { In vitro cytocompatibility with human osteoblast } \\
\text { cells from limb tissue (ATCC CRL-11372); } \\
\text { Stimulates osteoblasts adherence and } \\
\text { proliferation; } \\
\text { Can be used for radioactive synovectomy to treat } \\
\text { haemophilic synovitis. }\end{array}$ & {$[267,331-333]$} \\
\hline $\mathrm{Cd}$ & Powder & $\mathrm{n} / \mathrm{a}$ & O & $\begin{array}{l}\text { High toxicity on zebra fish, which died after } \\
\text { Cd-Ha exposure; } \\
\text { Toxic effect on the growth of plants. }\end{array}$ & {$[334,335]$} \\
\hline $\mathbf{W}$ & Powder & $0.7-32.3$ & 0 & $\begin{array}{l}\text { Catalytic activity by enhancing the biosorption and } \\
\text { adsorption of methyl orange by E. faecalis bacteria } \\
\text { and further decolourization and removal from } \\
\text { waste water; } \\
\text { Increases gamma radiation absorption, which } \\
\text { makes it useful in radiation shielding. }\end{array}$ & [336] \\
\hline Hf & Powder & $0.5-15$ & $\mathrm{O}$ & $\begin{array}{l}\text { Cytotoxic to A549 human adenocarcinoma } \\
\text { alveolar epithelial cells, when Hf-HA is used in } \\
\text { combination with ionizing radiation } \\
\text { (photodynamic therapy); } \\
\text { In vivo (mice) tests show tumour reduction after } \\
\text { using ionizing radiation and Hf-HA nanoparticles. }\end{array}$ & [339] \\
\hline La & $\begin{array}{l}\text { Powder } \\
\text { Coating }\end{array}$ & $2-30$ & O & $\begin{array}{l}\text { In vitro cytocompatibility with MC3T3-E1 and } \\
\text { L929 cell lines; } \\
\text { No cytotoxicity for adenocarcinoma (MCF-7) and } \\
\text { human embryonic kidney HEK cells at a doping } \\
\text { level of } 2 \text { at.\%; } \\
\text { Antibacterial effect against S. aureus (e.g., ATCC } \\
\text { 25175), E. coli, P. aeruginosa, and Bacillus; } \\
\text { Improvement of mechanical properties: bonding } \\
\text { strength and Vickers hardness. }\end{array}$ & $\begin{array}{l}{[314,340,342} \\
379,380,405]\end{array}$ \\
\hline
\end{tabular}


Table 3. Cont

\begin{tabular}{|c|c|c|c|c|c|}
\hline $\begin{array}{l}\text { Cation } \\
\text { (M) }\end{array}$ & $\begin{array}{l}\text { Sample } \\
\text { Form }\end{array}$ & $\begin{array}{c}\text { Doping Range } \\
{[\mathrm{M} /(\mathrm{M}+\mathrm{Ca})]} \\
100(\text { at. } \%)\end{array}$ & & Bio-Functionality/Effect of the Dopant & Refs. \\
\hline $\begin{array}{c}\mathrm{Ce} \\
(3+)\end{array}$ & $\begin{array}{l}\text { Powder } \\
\text { Coating }\end{array}$ & $4-20$ & 0 & 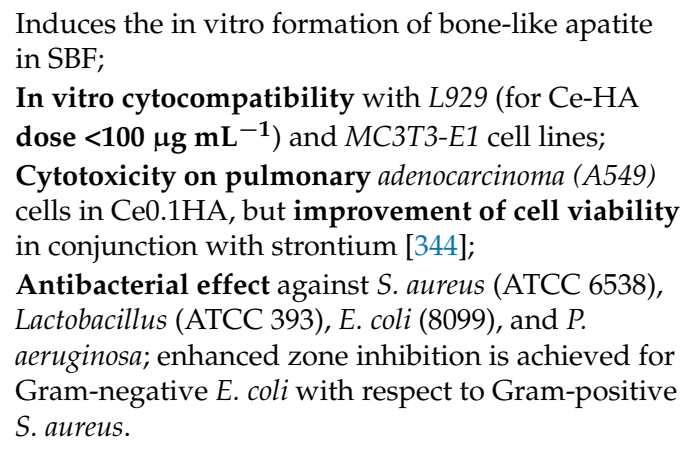 & $\begin{array}{c}{[344,346,377} \\
382-384]\end{array}$ \\
\hline $\begin{array}{l}\mathrm{Ce} \\
(4+)\end{array}$ & Powder & $0.1-0.5$ & $\bigcirc$ & $\begin{array}{l}\text { In vitro cytocompatibility with MG63 (Ce-HA-NPs } \\
\text { at doses in the range } 200-600 \mu \mathrm{gL}^{-1} \text { ); } \\
\text { Increase of MG-63 cell viability, proliferation and } \\
\text { differentiation at doses of } 200-400 \mu \mathbf{g L}^{-1} \text {; } \\
\text { Antibacterial effect against } S \text {. aureus (ATCC } 6538 \text { ), } \\
\text { Lactobacillus (ATCC 393), Bacillus subtilis, E. coli (714), } \\
\text { and P. aeruginosa; } \\
\text { Significant decrease of bacteria number when } \\
\text { coupled with } \mathrm{Fe}_{3} \mathrm{O}_{4} \text { NPs. }\end{array}$ & {$[348,381,385]$} \\
\hline Sm & $\begin{array}{l}\text { Powder } \\
\text { Coating }\end{array}$ & $0.2-0.5$ & O & $\begin{array}{l}\text { In vitro cytocompatibility with HFOB } 1.19 \text { cell line } \\
\text { (comparable to pure HA control specimens); } \\
\text { Antibacterial effect against S. aureus, E. faecalis, E. } \\
\text { coli, and P. aeruginosa. Differences in the extent of } \\
\text { antibacterial activity for Gram-positive and } \\
\text { Gram-negative stains; } \\
\text { Antifungal effect against C. albicans (ATCC 10231). }\end{array}$ & {$[355,357]$} \\
\hline Eu & Powder & $0.1-20$ & $\mathrm{O}$ & $\begin{array}{l}\text { Induces the in vitro formation of bone-like apatite } \\
\text { in SBF; } \\
\text { In vitro cytocompatibility with MG-63 (cell } \\
\text { proliferation up to } 4 \text { days), HeLa, human embryonic } \\
\text { kidney HEK } 293, \text { L929 (viability }>80 \% \text { for Eu-HA } \\
\text { doses of } 25-500 \mu \mathbf{~ m L}^{-1} \text { ); } \\
\text { Low cytotoxicity for human gingival fibroblast } \\
\text { (HGF-1) cells after } 24 \text { h (500-2000 } \mu \mathbf{g ~ m L}^{-1} \text { ); } \\
\text { Cytotoxicity for transformed human umbilical vein } \\
\text { endothelial cells (T-HUVEC) after treatment with at } \\
\text { 0.3-30 } \mu \text { g } \mathbf{~ m L}^{-1} \text { of } \mathbf{5} \text { at.\% doped HA; } \\
\text { Ability to kill cervical HeLa cells after } 24 \text { when } \\
\text { combined with } 5 \text { fluorouracil (5FU); } \\
\text { Negligible toxicity by hen's egg test on the chick } \\
\text { area vasculosa (HET-CAV); } \\
\text { Antibacterial effect against E. faecalis (ATCC 29212), } \\
\text { S. aureus (0364), and P. aeruginosa (1397); No } \\
\text { antibacterial activity against E. coli even at } \\
\text { high doping; } \\
\text { Antifungal effect against C. albicans (ATCC 10231) } \\
\text { with only for a doping content of } 20 \text { at.\%. }\end{array}$ & $\begin{array}{c}{[361-366,388-} \\
393]\end{array}$ \\
\hline $\mathbf{T b}$ & Powder & $2-17$ & $\mathrm{O}$ & 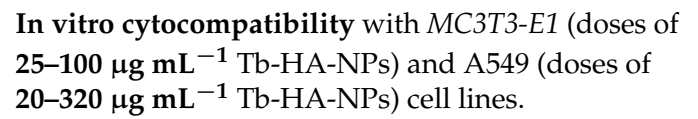 & {$[361,393,399]$} \\
\hline Gd & Powder & $1-17$ & $\mathrm{O}$ & $\begin{array}{l}\text { In vitro cytocompatibility with } H F O B 1.19 \text { for } \mathrm{x}_{\mathrm{Gd}} \\
<17 \%\left[\mathrm{Ca}_{10-\mathrm{x}} \mathrm{Gd}_{\mathrm{x}}\left(\mathrm{PO}_{4}\right)_{6}(\mathrm{OH})_{2}\right] \text { cell line; } \\
\text { Cytotoxicity for } \mathrm{HFOB} 1.19 \text { cells at } \mathrm{x}_{\mathrm{Gd}} \sim 17 \% \text {. }\end{array}$ & [128] \\
\hline
\end{tabular}


Table 3. Cont.

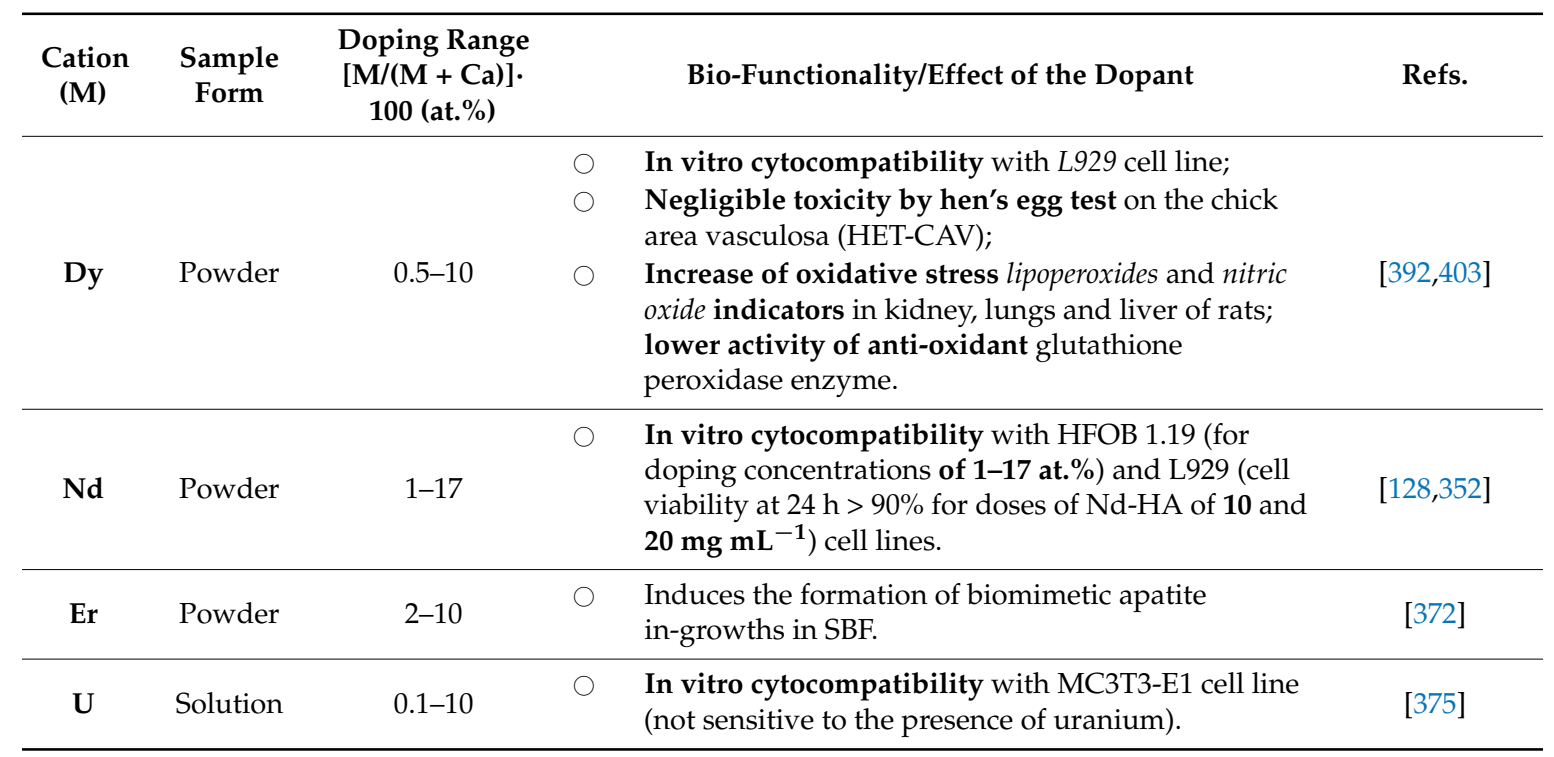

\subsection{Cytotoxic Concentration of Cationic Species}

Literature data on the actual cytotoxic cation release rates for this large variety of doped/ substituted hydroxyapatite materials are rather scarce. Most researchers prefer to discuss the theoretical and/or experimental total cation dopant concentration [doping cation/(doping cation + Ca)] introduced into hydroxyapatite, and/or total dose concentration of doped-HA added to the cell media. When examining the dopants' total content and their influence, contradictory cytotoxic levels are often signalled. This is to be expected since the cation release rate is governed by a series of factors such as crystallinity or particle morphology and size of the tested material, which are strongly dependent on dissimilarities in the chosen synthesis method, technological preparation recipes and post-synthesis processing stages. The authors advocate a more intimate understanding of the cation-substituted HA interaction with physiological media and cells, which can only be achieved by insightful studies (always including a control specimen of pure stoichiometric HA, comparing in the framework of a study the effect of more than one cation, focusing on the actual ionic release rates and not on the doped HA powder doses only). It is recommended for researchers to couple their bio-functional assays with determination of the temporal ion-release profiles, determined for instance by ICP techniques (with ppm/ppb sensitivity). Such systematic studies could help collate the prerequisite multiple and congruent demonstrations on the promise of a given cation and its optimal action dose, enable trustworthy conclusions, and allow for a reliable and safe transition of doped-HA from research bench-work to commercial and/or clinical applications, with great health and societal impacts.

Further scientific literature surveys were dedicated to the identification of cytotoxic concentration of the cations under scrutiny here, irrespective of their host material. The gathered information, presented in Figure 4, indicates a seemingly non-inhomogeneity of existing data. But this is only apparent because the cytotoxic concentration threshold which induced a cell's growth decrease by $50 \%$ is dependent on a large palette of influential factors: source material of the ion [406-408], crystalline quality (a lower crystallized material will possess a higher free energy and ion molecular mobility, the consequence of which is accelerated degradation rates, and thereby faster release of active agents [409,410]), particle size (which influence the total active surface area) [411-415], shape/morphology of the particles (e.g., spheres, polyhedra, rods, platelets, random) [414,416-419], valance and oxidation state of the cation [420-425], cells line type, and incubation time [407,408,413, $419,426,427]$. 


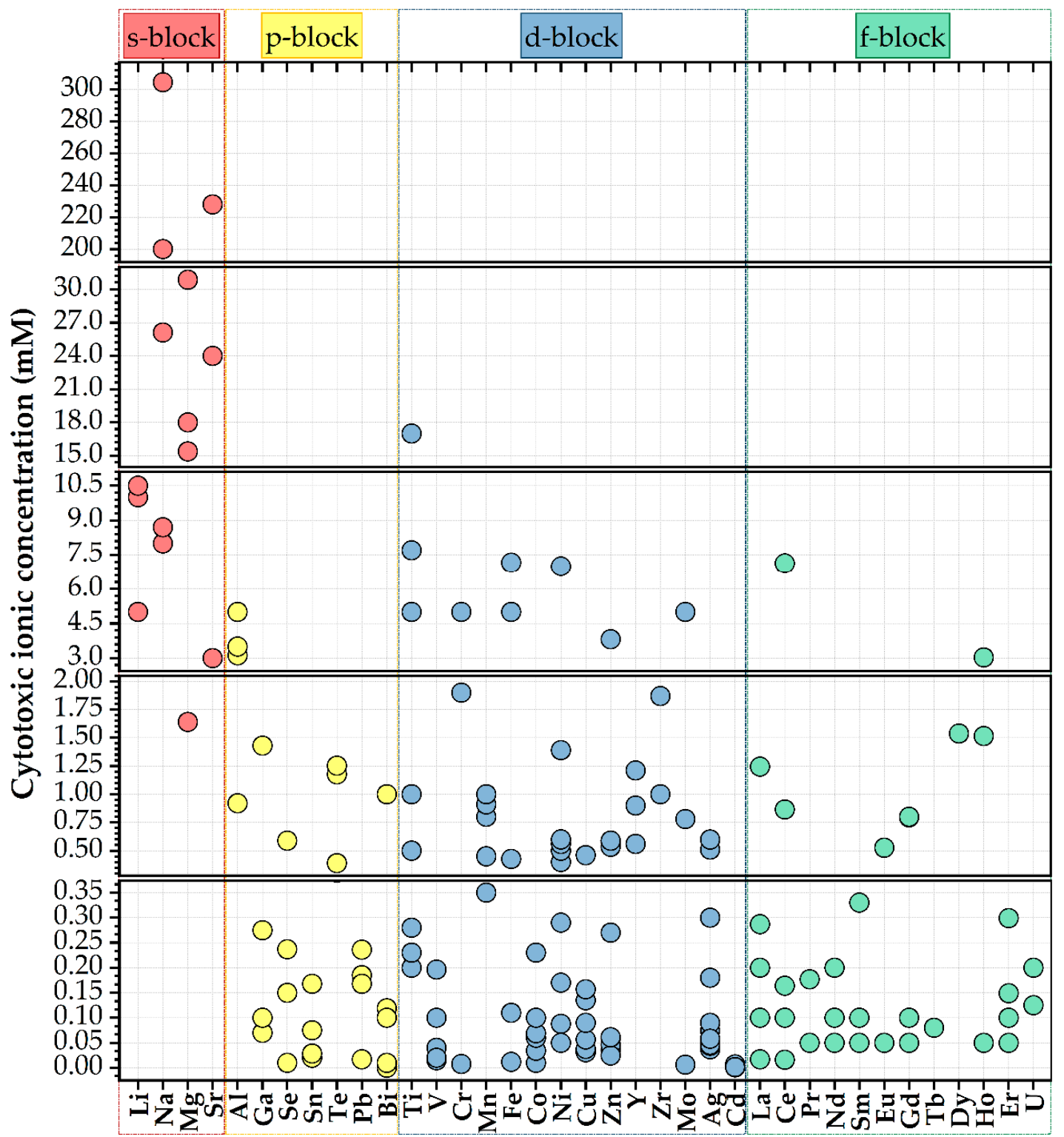

Figure 4. Half-maximal cytotoxic concentration (in $\mathrm{mM}$ ) of various cationic species: Li [428-430], $\mathrm{Na}$ [431-434], Mg [435-438], Sr [439-441], Al [442-444], Ga [408,445], Sn [406,446,447], Te [448-450], $\mathrm{Pb}$ [427,451], Bi [452-455], Ti [406,408,443,444,456,457], V [408,442-444], Cr [408,442-444], Mn [443,458460], Fe [426,442,443,461], Co [406,408,442-444,462,463], Ni [406,408,430,443-445,462-465], Cu [406,408, 445,462,466], Zn [406,408,457,462,467], Y [468-470], Zr [406,442], Mo [442,443,471,472], Ag [406,408,445, 471,473-476], Cd [408,462,471], La [477-479], Ce [406,480-482], Pr [480,483], Nd [480,484], Sm [480,485], Eu [477,480], Gd [480,486,487], Tb [488], Dy [485], Ho [480,485,489], Er [480,483,485], U [490,491].

\section{Rigorous In Vitro Testing of Bioactive Materials}

With the current regulations regarding in vivo studies (highly restrictive in the European Union) it is mandatory to identify in vitro protocols that would return reliable results, and reduce the number of materials suitable to enter in the in vivo studies to one or maximum two.

Thereby, when designing a medical device with enhanced properties (e.g., biomineralization capacity, osteoconductivity, angiogenic potential, or antimicrobial activity), the in vitro assay protocols need to allow a facile and trustworthy comparison between studies and results reported by individual research groups. 
At the international level, there are a series of ISO standards that include recommendations concerning biological testing procedures and qualitative and quantitative evaluation markers. However, each of the ISO standards is dedicated to a definite material property, and employs a different type of testing media, with different degree of compositional complexity, used under various ambient conditions:

- ISO 10993-14:2001-Biological Evaluation of Medical Devices-Part 14: Identification and Quantification of Degradation Products from Ceramics. Medium for extreme tests: buffered citric acid solution, $\mathrm{pH}=3.0 \pm 0.2$ at a temperature of $37 \pm 1{ }^{\circ} \mathrm{C}$, in normal atmosphere; Solution for simulated tests: buffered tris(hydroxymethyl)aminomethane (Tris)-HCl solution, $\mathrm{pH}=7.4 \pm 0.1$ at a temperature of $37 \pm 1^{\circ} \mathrm{C}$, in normal atmosphere.

- ISO 16428:2005-Implants for Surgery-Test Solutions and Environmental Conditions for Static and Dynamic Corrosion Tests on Implantable Materials and Medical Devices. Medium: aqueous solution of sodium chloride $(0.9 \% \mathrm{NaCl}$ mass fraction) or Ringer's solution isotonic aqueous solution of $\mathrm{NaCl}$, $\mathrm{pH}=7.0$ at a temperature of $37 \pm 1{ }^{\circ} \mathrm{C}$, in normal atmosphere.

- ISO 16429:2004-Implants for Surgery-Measurements of Open-Circuit Potential to Assess Corrosion Behaviour of Metallic Implantable Materials and Medical Devices over Extended Time Periods. Medium: aqueous solution of sodium chloride ( $0.9 \% \mathrm{NaCl}$ mass fraction), $\mathrm{pH}=7.0$ at a temperature of 37 $\pm 1{ }^{\circ} \mathrm{C}$, in normal atmosphere. For more stringent test conditions, more acidic test solutions are recommended.

- ISO 23317:2014-Implants for surgery_-In vitro Evaluation for Apatite-Forming Ability of Implant Materials. (i.e., Bioactivity/Biomineralization Capacity Testing). Medium: Tris-buffered simulated body fluid (ionic concentration in $m M: 142.0 \mathrm{Na}^{+}, 5.0 \mathrm{~K}^{+}, 1.5 \mathrm{Mg}^{2+}, 2.5 \mathrm{Ca}^{2+}, 147.8 \mathrm{Cl}^{-}, 4.2 \mathrm{HCO}_{3}{ }^{-}$, $1.0 \mathrm{HPO}_{4}{ }^{2-}$, and $\left.0.5 \mathrm{SO}_{4}{ }^{2-}\right), \mathrm{pH}=7.4$ at a temperature of $36.5 \pm 0.2{ }^{\circ} \mathrm{C}$, in normal atmosphere.

- ISO 10993-5:2009_Biological Evaluation of Medical Devices—Part 5: Tests for in vitro Cytotoxicity. Medium: culture medium (e.g., Dulbecco's Modified Eagle Medium) with or without serum such as to meet the growth requirements of the selected cell line, $\mathrm{pH}=7.4$ at a temperature of $(37 \pm 1){ }^{\circ} \mathrm{C}$, in a humidified atmosphere of $5 \% \mathrm{CO}_{2}$.

- ISO 22196:2011-Measurement of Antibacterial Activity on Plastics and Other Non-Porous Surfaces. Medium for suspension assays: nutrient broth (containing meat extract, peptone, $\mathrm{NaCl}$ ), at a temperature of $(35 \pm 1){ }^{\circ} \mathrm{C}$ and a relative humidity of not less than $90 \%$ for $24 \pm 1 \mathrm{~h}$, in normal atmosphere.

In vivo testing should never be considered before a thorough in vitro investigation.

We shall briefly discuss the positive aspects and the shortcomings of the most frequently used in vitro tests.

\subsection{Biomineralization Capability (Bioactivity Testing)}

The existence of a soundly crafted standard is welcomed in our opinion, since it can lead to meta-analyses and to facile comparisons between materials explored in different studies. However, a poorly and outdated standard can harm scientific endeavours and limit important and significant discoveries that can be safely transferred into medical practice.

For instance, the current in vitro standard for biomineralization testing (i.e., ISO 23317:2014) is, in our opinion, scientifically outdated, as it uses a purely inorganic solution (simulated body fluid, SBF), supersaturated towards the HA components, under normal atmospheric conditions [492]. It has the "advantage" of delivering fast and almost always positive results, even for materials otherwise widely-considered inert [147,493-495]. Many groups have started to acknowledge these limitations and are actively seeking a more reliable bioactivity assay [492,496-500], proving that even in complex organic-inorganic media, under the correct biomimetic conditions, biomineralization can be successfully, but rigorously, tested. 
For some of the ISO tests performed in purely inorganic media (e.g., ISO 10993-14:2001) it is recognized that supplementary biological factors, such as amino-acids, enzymes and proteins, can change the solubility/degradation rate of the material, and this it is not accounted for. Since the doping ion release would be different in each of these dissimilar media, it seems rather difficult to cross-examine results obtained by applying such standardized in vitro testing protocols. When studying the capacity of a biomaterial to induce a process, the in vitro protocol should mimic as much as possible the conditions that the implant would encounter in vivo. Although, the in vivo conditions are very difficult to be replicated with high fidelity in vitro, we should all acknowledge the acute need for improved and congruent protocols. As opposed to the SBF assay, which suggests a nearly universal biomineralization capability of materials, a test performed in complex media such as Dulbecco's modified Eagle's medium (DMEM)-like cell culture medium supplemented with serum $(10 \%)$, produces biomineralization only for truly bioactive materials [496-500], being thus a reliable refinement tool for innovative material designs.

Only a rigorous and homogenous testing of bioceramics can filter the best material designs from abundant possibilities, and allow for a rapid translation to clinical applications. Thereby, we, along with an increasing number of researchers [497-500], would recommend advanced biomimicry testing of the biomineralization potential, using cell cultures media supplemented with $10 \%$ serum at $37^{\circ} \mathrm{C}$, in a humid atmosphere with $5 \%$ partial pressure of $\mathrm{CO}_{2}$ (as found in living tissues).

\subsection{Degradation and Corrosion Tests}

Three ISO standards (ISO 10993-14:2001, ISO 16428:2005, ISO 16429:2004) offer recommendations for such tests, but a series of issues persist:

i Using pure inorganic fluids for testing (i.e., citric acid, (Tris)- $\mathrm{HCl}, 0.9 \% \mathrm{NaCl}$, Ringer's solutions) is not a viable choice because, as presented before, the organic component of the intercellular fluid interacts with the implant surface and greatly modifies the interactions with the biomaterial. The use of a suitable testing environment is of foremost importance since these specific material features (degradation rate and corrosion resistance) are dependent on the material surface properties and its ability to adsorb organic moieties, partial dissolution and the consequent ionic exchanges.

ii In the attempt to compress the time needed for a degradation test and peek into the future, the ISO 10993-14:2001 standard uses buffered citric acid solution (at a $\mathrm{pH}=3.0 \pm 0.2$ ) to force degradation. However, since this solution is only inorganic and with a $\mathrm{pH}$ value never to be encountered at the implantation site, results can significantly vary from the actual events that will occur in vivo for the tested material over the long-term.

iii Such standards are designed mainly for testing bulk materials, and are focused on the weight of the specimen, not taking into account one of the most important parameters: the contact area with the fluid. The focus is on the ratio between the mass of specimen and volume of fluid, but systems to be studied differ a lot with respect to the interaction area per gram of substance. Pellets, scaffolds (with macro- and micro-porosity), powders with different particle size, and thin (or thick) smooth (or rough) films induce huge differences in the ratios between the mass of substance and the area of interaction with the testing medium. An overview of this particular matter along with a several proposals can be found in [492].

\subsection{Biocompatibility Assays}

Nowadays, the biocompatibility testing of a material with prospects for biomedical application, is mandatory. Different cell lines are used to assess cell proliferation, cell toxicity, capacity to induce bone matrix formation, and cell differentiation. The ISO 10993-5:2009 standard recommends for extract testing, direct contact, and indirect contact procedures testing periods of $24 \mathrm{~h}$, at least $24 \mathrm{~h}$, and between 
24 and $72 \mathrm{~h}$, respectively. The standard lays the ground for some basic biocompatibility tests, but its concepts might be considered somewhat outdated.

Cell proliferation can be evaluated by:

i Classic, MTT (3-(4,5-Dimethylthiazol-2-yl)-2,5-Diphenyltetrazolium Bromide), MTS (3-(4,5dimethylthiazol-2-yl)-5-(3-carboxymethoxyphenyl)-2-(4-sulfophenyl)-2H-tetrazolium)), XTT (2,3-bis-(2-methoxy-4-nitro-5-sulphenyl)-(2H)-tetrazolium-5-carboxanilide) assays, that returns a value linked to general mitochondrial activity of the cells. Errors are given by different factors (e.g., differentiation of stem cells induces growth of mitochondria number per cell and increased activity). Advantages: simple and fast procedure, reliable results when working with homogenous terminally differentiated cells, cheap equipment and kits; Disadvantages: low reliability when working with heterogeneous cell cultures for differentiating experiments, indirect measure of proliferation;

ii Quantifying double-stranded (ds) DNA by fluorescence (more ds-DNA, means more cells, ergo higher proliferation). Commercial kits are available. Advantages: direct measure of proliferation, very good and reliable results when working with heterogeneous cell cultures with many cell types (differentiation experiments), affordable equipment (98 well fluorescence reader), commercial kits are available; Disadvantage: complicated procedure;

iii Cell counting when possible. Advantage: can be somewhat automated with a flow cytometer; Disadvantages: the classic counting technique uses microscopy, which is very laborious, time consuming, and impossible when dealing with a large number of situations (i.e., at least 10 microscopy fields per situation are required, with minimum 500 cells, numbered by three different examiners).

Cell toxicity can be evaluated by:

i Studying their morphology, when possible (as presented in ISO 10993-5:2009). This is a laborious method as it requires examination of a minimum 500 cells per situation acquired from a minimum 10 different randomly-chosen microscopy fields by three separate individuals. This renders the method almost impossible, when the experiment would involve a large number of materials;

ii Measuring the LDH (lactate dehydrogenase) activity in the medium in which the cells were cultivated. LDH is an active intracellular enzyme found in all cells. Upon death, the cell releases this LDH into the medium and, therefore, this enzyme activity is proportional to the number of dead cells [501]. The method is easy to perform, fast, and returns reliable results on the same samples investigated for cell proliferation by mitochondrial activity tests;

ii Measuring mitochondrial activity (MTT, MTS, XTT), as presented in the ISO 10993-5:2009 standard. It is a surrogate test for cytotoxicity: lower values with respect to control, due to lower general mitochondrial activity, are interpreted as results of cellular death, but this can also be an effect of slower proliferation values induced by the material. Thereby, it should not be used as stand-alone assay for cytotoxicity;

iv Fluorescence apoptosis and cell viability kits (e.g., DAPI, annexinV, propidium iodide kit and Calcein AM/EthD-1 kit) are simple and widely used assays that provide good results, especially for flat substrates and examination with a confocal microscope. Calcein AM enters live cells and is converted in the cytoplasm in a green fluorescent compound, which does not exit from the cytoplasm. The dead cell nuclei have a red fluorescence due to EthD-1 that can penetrate only through the membrane of dead cells. As such, by fluorescence confocal microscopy the ratio of dead cells can be assessed. For 3D scaffolds it provides good results when the reading is done by a flow cytometer only, if the protocol recuperates and counts also the prior detached cells (which makes it a more difficult variant);

v Measuring the intracellular colorant uptake, as presented in the ISO 10993-5:2009 standard. The procedure is time consuming, but offers reliable results. 
For biocompatibility we would suggest using a LDH activity kit in conjunction with a MTS/XTT/MTT assay in order to counteract the errors that may occur from high proliferation coexistence with high apoptosis.

The shape of the material to be tested can vary and can pose great challenges. The easiest situation for cell culturing is constituted by dense and smooth coated specimens. In the case of bulk material specimens, flat surfaces (to be obtained by polishing) with same area are needed as well.

The most problematic situation is represented by the porous scaffolds, produced by various additive manufacturing techniques. Frequently these types of testing samples have two degrees of porosity: (i) micro-porosity generated by elimination of substances needed to produce the ink or the carrying thermoplastic filament compounds; and (ii) a macro-porosity resulting from the designed spacing between the individual material rods, which is usually situated in the range 100-500 $\mu \mathrm{m}$.

The challenge arises from the difficulty of uniformly seeding a certain number of cells into the scaffold. The detached cells have a diameter of $\sim 15 \mu \mathrm{m}$ and fall through the rods of the scaffold to the bottom of the well. Also, when comparing scaffolds with different macro-porosity (different spacing between the rods) the problem becomes even more complicated, as the available space in the scaffold is different.

We did not find in the literature a protocol that would allow the seeding of identical numbers of cells in scaffolds with different macro-porosity.

\subsection{Osteoinduction Ability}

In order to enhance bone healing, few methods to boost osseointegration, cytocompatibility and bone matrix production were envisioned. As such along with incorporation/adsorption of growth factors that stimulates osteoblastic lineage [502-504], some cation doping into HA was also extensively investigated, as was shown in the previous sections of this review.

The most common protocols to assess the formation of new bone matrix involve the alizarin red technique. However, when cells are grown on opaque substrates (such as titanium) that do not allow bright-field microscopy assessment, other means of investigation must be searched for.

One other solution is to quantify the proteins (i.e., collagen, ostein, osterix, osteopontin) present in the matrix formed by the cells, by immunofluorescence techniques. Quantification of such protein and cell solubilisation markers by enzyme-linked immunosorbent assay (ELISA) or the Western blot method is more difficult, but delivers better results.

\subsection{Cell Differentiation Capacity}

In order to boost bone healing, a great number of osteoblasts is needed, and the simplest solution would consist in the ability of the implant material to boost stem cell differentiation toward osteoprogenitor cells and osteoblasts.

Nowadays, seemingly the most desired property of HA materials is the capacity to induce stem cell differentiation. In the quest to obtain fast healing, the scientists could fall into the grave error of inducing the disappearance of the stem cell pool, and thereby generating a high risk of implant failure in the long-term. Indeed, in a study performed by Popa et al. [15], it was shown that bone is a complex organ subjected to continuous remodelling processes, and if inducing a rapid large-scale differentiation of stem cells, a great number of osteoprogenitor cells would be produced, but, after a period of time, the osteoprogenitor cells will cease to exist as a consequence of the stem cell pool absence.

The generation of osteopotent daughter cells in sufficient number to induce healing, is a complex phenomenon which should be reserved to the cell signalling between stem cells and their niche and inflammatory cells present at implantation site/wound. The stem cells pool, along with its niche and the complex signalling processes are a micro-universe yet to be fully understood. The authors advise fellow researchers to act with caution when integrating biomaterials that possess the ability to force abrupt stem cell differentiation. In the absence of long-term in vivo evidences on the biological 
outcome of such materials, awareness/caution on the risks of meddling with stem cell signalling is in our opinion still necessary.

Osteogenic differentiation can be studied using immunofluorescence for markers specific to osteoblastic lineage such as: extracellular matrix proteins (e.g., collagen, osteopontin, osteocalcin, bone sialoprotein) or intracellular proteins which have enzymatic function (e.g., alkaline phosphatase) [505]. The cells marked with fluorochromes can be viewed with an epi-fluorescence or confocal microscope. Production of bone by osteoblasts could be investigated also by cyto-chemistry methods (e.g., alkaline phosphatase activity assay). More complex techniques, that are not at hand for most scientists due to the high cost of equipment and kits, are transcriptomics, proteomics and metabolomics. An extensive survey of the RNA profile of the cells by DNA microarray or real-time polymerase chain reaction (real-time PCR) can confer clarity regarding the stage of cell differentiation and the mechanism of this process [506].

The von Kossa assay produces a black-grey stain where Ca deposits are located in the tissue by replacing $\mathrm{Ca}$ ions with silver ones. Therefore, the von Kossa assay could be only applied for in vitro tests that incubate osteoprogenitor cells with cell-growing medium that was in contact with the powders/scaffolds of calcium phosphates (HAs included).

\subsection{Pro-Angiogenic Properties}

The capacity to induce angiogenesis is envisioned as an important trait of a scaffold, since it will help healing by generating a sufficient blood supply for the cells that will colonize the implant. For metallic implants coated with HA there is no need for a pro-angiogenesis property, since the healing will take place only on a surface and the normal bone around the implant will produce all the blood vessels it needs.

The cells that will produce new blood vessels derive from stem cells through proliferation towards an angiogenic fate. The angiogenic lineage results from the modifications in a constellation of signalling molecules: pro-inflammatory cytokines, interleukins, stem cell factor, Notch, Vascular endothelial growth factor (VEGF), epidermal growth factor (EGF), fibroblast growth factor (FGF), platelet derived growth factor (PDGF), insulin-like growth factor (IGF), tumour necrosis factor alpha/beta (TNF), transforming growth factor beta 1 and 2 (TGF- $\beta 1$ \& TGF- $\beta 2$ ), or Wnt $[507,508]$.

One possibility for generating blood vessels in the scaffold is to use recombinant pro-angiogenic growth factors such as, VEGF, PDGF, IGF, or TGF- $\beta 1$ \& TGF- $\beta 2$ adsorbed into the scaffold $[502,509]$. These proteic substances are difficult to manage and manipulate, expensive and would require a complex authorization and quality control. Therefore, some ion additions (e.g., $\mathrm{Li}, \mathrm{Co}, \mathrm{Ni}, \mathrm{Mg}, \mathrm{Sr}, \mathrm{La}$ ) in the HA scaffold have been envisaged as a simple and cheap alternative $[222,328,340,510,511]$. To date, more than 120 articles have been published on this topic. Some of these studies reached an in vivo phase with encouraging results [512-516]. However, it is important to use a doping concentration that generates the desired angiogenic effect, but does not exhibit toxic side effects on a long-term ion release. In vivo angiogenesis studies typically witness micro-vascularisation formation, along with growth of blood vessels with a greater diameter. However, questions about the long-term adverse side-effects on the healing process, such as the generation of too many blood vessels and the out-growth of the implant, need to be addressed as well in the future.

Furthermore, numerous groups found that macro-porosity greatly influences the vascularisation of ceramic scaffolds. While a pore dimension over 30-40 $\mu \mathrm{m}$ can enable endothelial cells to enter the scaffold [517,518], larger pore sizes $(>150 \mu \mathrm{m})$ facilitate the development of blood vessels with greater diameter and total volume, upon in vivo implantation [519]. This effect is observed until a pore size of $500 \mu \mathrm{m}$, where the plateau of blood vessels diameter and volume is reached [520-522].

In vitro pro-angiogenic properties investigations can be carried out on endothelial cell cultures, as the viability, proliferation, and cytotoxicity of such cell lineages is basic. 
More complex experiments would imply (i) measuring of the amount of pro-angiogenic factors secreted by these cells when cultivated in the presence of HA materials, or (ii) RNA quantification of the activation of the proangiogenic genes.

\subsection{Antimicrobial Activity}

Most studies determine the antimicrobial activity on both Gram-positive and Gram-negative bacterial strains, having as major exponents S. aureus and E. coli. These bacteria are the most frequently met in implant infections.

The ISO 22196:2011 standard provides a protocol for antimicrobial testing of bulk and thin films of biomaterials with nutrient broth and S. aureus or E. coli. There are some limitations:

i The tested material should be flat and compact with a surface of minimum $6.25 \mathrm{~cm}^{2}$, of which $4 \mathrm{~cm}^{2}$ should be reserved for bacterial interaction;

ii Various types of nutrient broth have been observed to interact differently with the biomaterials, causing a variety of degradation rates, and therefore dissimilar antibacterial activities;

iii Because of their nature and geometry, powders and 3D scaffolds with macro- and micro-porosity, cannot be tested according to this ISO standard protocol. Therefore, adaptive measures should be devised.

For powders:

A nutrient media powder suspension is inoculated with a known number of colony-forming units (CFU) to a final concentration of around $10^{5}-10^{6} \mathrm{CFU} \mathrm{mL}{ }^{-1}$, under continuous agitation in an incubator at $37^{\circ} \mathrm{C}$ for a desired period of time. The number of bacterial cells that remained viable (viable cell count, VCC) is to be investigated by serial dilutions from each situation and seeding on simple agar plates (in an analogue manner to the ISO standard protocol);

- Colorimetric or fluorescence tests can be performed on samples, and rapid results are obtained based on previous control measuring curves established for each type of bacteria (e.g., MTS/XTT, cresyl violet, fluorescein diacetate). The fluorescence techniques use more expensive reagents and readers, but their measurement is more reliable since turbidity of the sample generated by powder material dissolution does not affect the reading. Fluorescein diacetate is used in a standard method for the assessment of water contaminated with microorganisms and could be considered very reliable.

For 3D scaffolds:

- The scaffold would require an incubation in a given volume of nutrient media inoculated with a known number of CFU;

- Antimicrobial activity of a 3D structure is very hard to investigate because not all the bacterial cells can be harvested, since some of them could be very strongly adhered inside the scaffold, and therefore hard to detach;

- After the desired testing period, since the bacterial cells could be adhered inside the scaffold and cannot be reached, only a reading of a soluble coloured/fluorescent product of bacterial metabolism can provide insights. Some materials absorb coloured substances and make such tests impossible to carry out.

\section{Future Perspectives: Co-Substituted Hydroxyapatite Bioceramics}

Nowadays, as we enter the era of personalized medicine, the design of a successful implant implies making the right compromises with respect to the material formulation, shape, structure, mechanical performance, biocompatibility, pro-angiogenic or pro-osteogenic properties, and widerange antimicrobial activity, so as to aptly and comprehensively respond to the patient's problem. Starting with natural cation and anion doping $(\mathrm{Na}, \mathrm{Mg}, \mathrm{Sr}$, carbonates, $\mathrm{Cl}, \mathrm{F})$ and the trace elements 
( $\mathrm{Zn}, \mathrm{Cr}, \mathrm{Co}, \mathrm{Mn}, \mathrm{Si}$ ) that are naturally found in human bones [5], the synthesis of co-substituted HA could pave a way toward the design of implants with combined multi-biofunctionality.

In the realm of antimicrobial efficiency, multiple doping with low ionic contents in HA seems to be the key to achieving potent activity, capable of combating the resilience of the microorganisms even adapted to conventional antibiotics, while limiting the toxic side effects. The simultaneous release of ions with different action mechanisms could enable not only preventing the adaptation of bacteria and fungi, but also widening the antimicrobial range against more pathogen strains.

In this respect, we acknowledge the recent contributions focused to ascertain both synergic ion doping combinations and their optimal concentration. So far, HA has been co-substituted with: $\mathrm{Ag} / \mathrm{Bi}$ [523], Ag/F [524], Ag/Mg [525,526], Ag/Si [527], Ag/Sr [528,529], Ag/Zn [281,530], $\mathrm{Ce} / \mathrm{Fe}$ [381], Ce/Eu [531], Sr/Ce [344,532], Sr/Cu [533], Sr/Zn [534,535], Zn/Cu [533,536], Zn/F [78], $\mathrm{Zn} / \mathrm{Fe}$ [537], $\mathrm{La} / \mathrm{Ag}$ [405], La/Cu [538], Sm/Gd [354], Tb/Gd [539], Ce/Zr/F [540], Ag/Ti/F [541], $\mathrm{Mg} / \mathrm{Zn} / \mathrm{Co}$ [542], Sr/Co/F [543], Ag/Cu/Zn/F [544], or Ag/Cu/Zn/Ti [545].

HA-based medical devices could also be coupled with cell therapy, enhancing their short- and long-term performances. In this respect, promising results were obtained for autologous stem cells, osteoprogenitor cells, or bone marrow aspirates. Quarto et al. [546] have used with clinical success autologous stem cells to induce healing of large defects of long bones. Scaffolds of biomaterials cultivated with autologous osteoprogenitor cells, implanted to boost bone healing, have shown good results up to 7 years [547]. Bone marrow aspirates, "a cocktail" of stem cells, niche cells and differentiated cells, were also used in clinical studies with success rates of $80-90 \%$ to heal delayed or non-unions of long-bone fractures [548-551].

In the light of the numerous contradictions, signalled in this review, a more rigorous and systematic scientific approach is recommended, studying compositional series of substituted HA samples, avoiding splitting the research into a number of manuscripts, and always coupling the antimicrobial effect demonstration with cytotoxicity assays and determinations of the actual temporal release profiles of the therapeutic ions.

Author Contributions: T.T., L.M.B., I.M.B., and I.P. reviewed the cation-doped hydroxyapatite literature and prepared the original draft manuscript, whilst A.-C.P., performed the critical assessment of the most commonly used biological testing protocols. J.M.F.F., G.E.S., T.T. and A.-C.P. were in charge of the project supervision and final editing.

Funding: This research was funded by the Romanian Ministry of Research and Innovation, CCCDI-UEFISCDI, in the framework of project PN-III-P1-1.2-PCCDI-2017-0062 (contract no. 58)/component project no. 2. Core Program PN18-110101 support is also acknowledged.

Acknowledgments: T.T., A.-C.P., L.M.B., I.M.B., I.P. and G.E.S. acknowledge the support of the Romanian Ministry of Research and Innovation, CCCDI-UEFISCDI, in the framework of project PN-III-P1-1.2-PCCDI-2017-0062 (contract no. 58)/component project no. 2. J.M.F.F. is thankful for the support of the CICECO-Aveiro Institute of Materials (Ref. UID/CTM/50011/2013), funded by FEDER funds through the Operational Programme Competitiveness Factors (COMPETE 2020), and the Portuguese Foundation for Science and Technology (FCT) is acknowledged.

Conflicts of Interest: The authors declare no conflict of interest.

\section{References}

1. Antoniac, I.V. Handbook of Bioceramics and Biocomposites; Springer: Berlin, Germany, 2016; ISBN 978-3-31912461-2.

2. Mucalo, M. Hydroxyapatite (HAp) for Biomedical Applications; Elsevier: Amsterdam, The Netherlands, 2015; ISBN 978-1-782-42033-0.

3. Sassoni, E. Hydroxyapatite and other calcium phosphates for the conservation of cultural heritage: A review. Materials 2018, 11, 557. [CrossRef] [PubMed]

4. Eliaz, N.; Metoki, N. Calcium phosphate bioceramics: A review of their history, structure, properties, coating technologies and biomedical applications. Materials 2017, 10, 334. [CrossRef] [PubMed]

5. Šupová, M. Substituted hydroxyapatites for biomedical applications: A review. Ceram. Int. 2015, 41, 9203-9231. [CrossRef] 
6. Fihri, A.; Len, C.; Varma, R.S.; Solhy, A. Hydroxyapatite: A review of syntheses, structure and applications in heterogeneous catalysis. Coord. Chem. Rev. 2017, 347, 48-76. [CrossRef]

7. Dorozhkin, S.V. Calcium orthophosphate deposits: Preparation, properties and biomedical applications. Mater. Sci. Eng. C Mater. Biol. Appl. 2015, 55, 272-326. [CrossRef] [PubMed]

8. Hench, L.L.; Thompson, I. Twenty-first century challenges for biomaterials. J. R. Soc. Interface 2010, 7, S379-S391. [CrossRef] [PubMed]

9. Jones, J.R. Review of bioactive glass: From Hench to hybrids. Acta Biomater. 2013, 9, 4457-4486. [CrossRef] [PubMed]

10. Drago, L.; Toscano, M.; Bottagisio, M. Recent evidence on bioactive glass antimicrobial and antibiofilm activity: A mini-review. Materials 2018, 11, 326. [CrossRef] [PubMed]

11. Kargozar, S.; Hamzehlou, S.; Baino, F. Potential of bioactive glasses for cardiac and pulmonary tissue engineering. Materials 2017, 10, 1429. [CrossRef] [PubMed]

12. Stuart, B.W.; Gimeno-Fabra, M.; Segal, J.; Ahmed, I.; Grant, D.M. Degradation and characterization of resorbable phosphate-based glass thin-film coatings applied by radio-frequency magnetron sputtering. ACS Appl. Mater. Interfaces 2015, 7, 27362-27372. [CrossRef] [PubMed]

13. Stuart, B.W.; Gimeno-Fabra, M.; Segal, J.; Ahmed, I.; Grant, D.M. Mechanical, structural and dissolution properties of heat treated thin-film phosphate based glasses. Appl. Surf. Sci. 2017, 416, 605-617. [CrossRef]

14. Vichery, C.; Nedelec, J.-M. Bioactive glass nanoparticles: From synthesis to materials design for biomedical applications. Materials 2016, 9, 288. [CrossRef] [PubMed]

15. Popa, A.C.; Stan, G.E.; Enculescu, M.; Tanase, C.; Tulyaganov, D.U.; Ferreira, J.M.F. Superior biofunctionality of dental implant fixtures uniformly coated with durable bioglass films by magnetron sputtering. J. Mech. Behav. Biomed. Mater. 2015, 51, 313-327. [CrossRef] [PubMed]

16. Stuart, B.W.; Grant, C.A.; Stan, G.E.; Popa, A.C.; Titman, J.J.; Grant, D.M. Gallium incorporation into phosphate based glasses: Bulk and thin film properties. J. Mech. Behav. Biomed. Mater. 2018, 82, 371-382. [CrossRef] [PubMed]

17. Popa, A.C.; Marques, V.; Stan, G.E.; Husanu, M.A.; Galca, A.C.; Ghica, C.; Tulyaganov, D.U.; Lemos, A.F.; Ferreira, J.M.F. Nanomechanical characterization of bioglass films synthesized by magnetron sputtering. Thin Solid Films 2014, 553, 166-172. [CrossRef]

18. Stan, G.E.; Popa, A.C.; Bojin, D. Bioreactivity evaluation in simulated body fluid of magnetron sputtered glass and glass-ceramic coatings: A FTIR spectroscopy study. Dig. J. Nanomater. Biostruct. 2010, 5, 557-566.

19. Gerhardt, L.-C.; Boccaccini, A.R. Bioactive glass and glass-ceramic scaffolds for bone tissue engineering. Materials 2010, 3, 3867-3910. [CrossRef] [PubMed]

20. Szczes, A.; Holysz, L.; Chibowski, E. Synthesis of hydroxyapatite for biomedical applications. Adv. Colloid Interface Sci. 2017, 249, 321-330. [CrossRef] [PubMed]

21. Rahavi, S.S.; Ghaderi, O.; Monshi, A.; Fathi, M.H. A comparative study on physicochemical properties of hydroxyapatite powders derived from natural and synthetic sources. Russ. J. Non-Ferrous Met. 2017, 58, 276-286. [CrossRef]

22. Oladele, I.; Agbabiaka, O.; Olasunkanmi, O. Non-synthetic sources for the development of hydroxyapatite. J. Appl. Biotechnol. Bioeng. 2018, 5, 92-99. [CrossRef]

23. Sima, L.E.; Stan, G.E.; Morosanu, C.O.; Melinescu, A.; Ianculescu, A.; Melinte, R.; Neamtu, J.; Petrescu, S.M. Differentiation of mesenchymal stem cells onto highly adherent radio frequency-sputtered carbonated hydroxylapatite thin films. J. Biomed. Mater. Res. Part A 2010, 95, 1203-1214. [CrossRef] [PubMed]

24. Wang, P.; Zhao, L.; Liu, J.; Weir, M.D.; Zhou, X.; Xu, H.H. Bone tissue engineering via nanostructured calcium phosphate biomaterials and stem cells. Bone Res. 2014, 2, 14017. [CrossRef] [PubMed]

25. Sima, L.E.; Petrescu, S.M. Adhesion and osteogenic differentiation of human mesenchymal stem cells: Supported by b-type carbonated hydroxylapatite. In Stem Cells and Cancer Stem Cells; Hayat, M.A., Ed.; Springer: Berlin, Germany, 2012; Volume 6, pp. 247-259. ISBN 978-94-007-2992-6.

26. Willerth, S.M.; Sakiyama-Elbert, S.E. Combining stem cells and biomaterial scaffolds for constructing tissues and cell delivery. In StemBook; Harvard Stem Cell Institute: Cambridge, UK, 2008.

27. Ghassemi, T.; Shahroodi, A.; Ebrahimzadeh, M.H.; Mousavian, A.; Movaffagh, J.; Moradi, A. Current concepts in scaffolding for bone tissue engineering. Arch. Bone Jt. Surg. 2018, 6, 90-99. [PubMed]

28. Krishnamurithy, G. A review on hydroxyapatite-based scaffolds as a potential bone graft substitute for bone tissue engineering applications. J. Health Transl. Med. 2013, 16, 22-27. [CrossRef] 
29. Zhang, D.; Wu, X.; Chen, J.; Lin, K. The development of collagen based composite scaffolds for bone regeneration. Bioact. Mater. 2017, 3, 129-138. [CrossRef] [PubMed]

30. Marques, C.F.; Perera, F.H.; Marote, A.; Ferreira, S.; Vieira, S.I.; Olhero, S.; Miranda, P.; Ferreira, J.M.F. Biphasic calcium phosphate scaffolds fabricated by direct write assembly: Mechanical, anti-microbial and osteoblastic properties. J. Eur. Ceram. Soc. 2017, 37, 359-368. [CrossRef]

31. Kundu, B.; Lemos, A.; Soundrapandian, C.; Sen, P.; Datta, S.; Ferreira, J.; Basu, D. Development of porous HAp and $\beta$-TCP scaffolds by starch consolidation with foaming method and drug-chitosan bilayered scaffold based drug delivery system. J. Mater. Sci. Mater. Med. 2010, 21, 2955-2969. [CrossRef] [PubMed]

32. Ben-Nissan, B. Advances in Calcium Phosphate Biomaterials; Springer: Berlin, Germany, 2014; ISBN 978-3642-53980-0.

33. Avila, I.; Pantchev, K.; Holopainen, J.; Ritala, M.; Tuukkanen, J. Adhesion and mechanical properties of nanocrystalline hydroxyapatite coating obtained by conversion of atomic layer-deposited calcium carbonate on titanium substrate. J. Mater. Sci. Mater. Med 2018, 29, 111. [CrossRef] [PubMed]

34. Surmenev, R.A.; Surmeneva, M.A.; Ivanova, A.A. Significance of calcium phosphate coatings for the enhancement of new bone osteogenesis-A review. Acta Biomater. 2014, 10, 557-579. [CrossRef] [PubMed]

35. Graziani, G.; Boi, M.; Bianchi, M. A Review on ionic substitutions in hydroxyapatite thin films: Towards complete biomimetism. Coatings 2018, 8, 269. [CrossRef]

36. El Hadad, A.A.; Peón, E.; García-Galván, F.R.; Barranco, V.; Parra, J.; Jiménez-Morales, A.; Galván, J.C. Biocompatibility and corrosion protection behaviour of hydroxyapatite sol-gel-derived coatings on Ti6Al4V alloy. Materials 2017, 10, 94. [CrossRef] [PubMed]

37. Oskouei, R.H.; Fallahnezhad, K.; Kuppusami, S. An investigation on the wear resistance and fatigue behaviour of Ti-6Al-4V notched members coated with hydroxyapatite coatings. Materials 2016, 9, 111. [CrossRef] [PubMed]

38. Lim, H.-K.; Byun, S.-H.; Woo, J.-M.; Kim, S.-M.; Lee, S.-M.; Kim, B.-J.; Kim, H.-E.; Lee, J.-W.; Kim, S.-M.; Lee, J.-H. Biocompatibility and biocorrosion of hydroxyapatite-coated magnesium plate: Animal experiment. Materials 2017, 10, 1149. [CrossRef] [PubMed]

39. Berndt, C.; Hasan, F.; Tietz, U.; Schmitz, K.-P. A review of hydroxyapatite coatings manufactured by thermal spray. In Advances in Calcium Phosphate Biomaterials; Ben-Nissan, B., Ed.; Springer: Berlin, Germany, 2014; pp. 267-329. ISBN 978-3-642-53980-0.

40. Fukada, E.; Yasuda, I. On the piezoelectric effect of bone. J. Phys. Soc. Jpn. 1957, 12, 1158-1162. [CrossRef]

41. Ulstrup, A.K. Biomechanical concepts of fracture healing in weight-bearing long bones. Acta Orthop. Belg. 2008, 74, 291-302. [PubMed]

42. Uto, Y.; Kuroshima, S.; Nakano, T.; Ishimoto, T.; Inaba, N.; Uchida, Y.; Sawase, T. Effects of mechanical repetitive load on bone quality around implants in rat maxillae. PLoS ONE 2017, 12, e0189893. [CrossRef] [PubMed]

43. Ohashi, K.; Fujiwara, S.; Mizuno, K. Roles of the cytoskeleton, cell adhesion and rho signalling in mechanosensing and mechanotransduction. J. Biochem. 2017, 161, 245-254. [CrossRef] [PubMed]

44. Gittings, J.; Bowen, C.R.; Dent, A.C.; Turner, I.G.; Baxter, F.R.; Chaudhuri, J.B. Electrical characterization of hydroxyapatite-based bioceramics. Acta Biomater. 2009, 5, 743-754. [CrossRef] [PubMed]

45. Yamashita, K.; Kitagaki, K.; Umegaki, T. Thermal instability and proton conductivity of ceramic hydroxyapatite at high temperatures. J. Am. Ceram. Soc. 1995, 78, 1191-1197. [CrossRef]

46. Yamashita, K.; Owada, H.; Umegaki, T.; Kanazawa, T.; Futagami, T. Ionic conduction in apatite solid solutions. Solid State Ion. 1988, 28, 660-663. [CrossRef]

47. Gandhi, A.A.; Wojtas, M.; Lang, S.B.; Kholkin, A.L.; Tofail, S.A. Piezoelectricity in poled hydroxyapatite ceramics. J. Am. Ceram. Soc. 2014, 97, 2867-2872. [CrossRef]

48. Lang, S.; Tofail, S.; Gandhi, A.; Gregor, M.; Wolf-Brandstetter, C.; Kost, J.; Bauer, S.; Krause, M. Pyroelectric, piezoelectric, and photoeffects in hydroxyapatite thin films on silicon. Appl. Phys. Lett. 2011, 98, 123703. [CrossRef]

49. Lang, S.; Tofail, S.; Kholkin, A.; Wojtaś, M.; Gregor, M.; Gandhi, A.; Wang, Y.; Bauer, S.; Krause, M.; Plecenik, A. Ferroelectric polarization in nanocrystalline hydroxyapatite thin films on silicon. Sci. Rep. 2013, 3, 2215. [CrossRef] [PubMed] 
50. Basirun, W.J.; Nasiri-Tabrizi, B.; Baradaran, S. Overview of hydroxyapatite-graphene nanoplatelets composite as bone graft substitute: Mechanical behavior and in-vitro biofunctionality. Crit. Rev. Solid State Mat. Sci. 2017, 43, 177-212. [CrossRef]

51. Combes, C.; Cazalbou, S.; Rey, C. Apatite biominerals. Minerals 2016, 6, 34. [CrossRef]

52. Fleet, M.E.; Liu, X. Coupled substitution of type A and B carbonate in sodium-bearing apatite. Biomaterials 2007, 28, 916-926. [CrossRef] [PubMed]

53. Markovic, M.; Fowler, B.O.; Tung, M.S. Preparation and comprehensive characterization of a calcium hydroxyapatite reference material. J. Res. Natl. Inst. Stand. Technol. 2004, 109, 553-568. [CrossRef] [PubMed]

54. Fleet, M.E.; Pan, Y. Site preference of rare earth elements in fluorapatite: Binary (LREE + HREE)-substituted crystals. Am. Miner. 1997, 82, 870-877. [CrossRef]

55. Akram, M.; Ahmed, R.; Shakir, I.; Ibrahim, W.A.W.; Hussain, R. Extracting hydroxyapatite and its precursors from natural resources. J. Mater. Sci. 2013, 49, 1461-1475. [CrossRef]

56. Oktar, F.; Yetmez, M.; Gunduz, O. Novel hydroxyapatite (HA) production from synthetic and natural sources. Bioceram. Dev. Appl. 2017, 7, e109. [CrossRef]

57. Miculescu, F.; Mocanu, A.C.; Stan, G.E.; Miculescu, M.; Maidaniuc, A.; Cîmpean, A.; Mitran, V.; Voicu, S.I.; Machedon-Pisu, T.; Ciocan, L.T. Influence of the modulated two-step synthesis of biogenic hydroxyapatite on biomimetic products' surface. Appl. Surf. Sci. 2018, 438, 147-157. [CrossRef]

58. Maidaniuc, A.; Miculescu, F.; Voicu, S.I.; Andronescu, C.; Miculescu, M.; Matei, E.; Mocanu, A.C.; Pencea, I.; Csaki, I.; Machedon-Pisu, T. Induced wettability and surface-volume correlation of composition for bovine bone derived hydroxyapatite particles. Appl. Surf. Sci. 2018, 438, 158-166. [CrossRef]

59. Miculescu, F.; Maidaniuc, A.; Voicu, S.I.; Thakur, V.K.; Stan, G.E.; Ciocan, L. Progress in hydroxyapatite-starch based sustainable biomaterials for biomedical bone substitution applications. ACS Sustain. Chem. Eng. 2017, 5, 8491-8512. [CrossRef]

60. Rocha, J.; Lemos, A.; Agathopoulos, S.; Kannan, S.; Valerio, P.; Ferreira, J. Hydrothermal growth of hydroxyapatite scaffolds from aragonitic cuttlefish bones. J. Biomed. Mater. Res. Part A 2006, 77, 160-168. [CrossRef] [PubMed]

61. Rocha, J.; Lemos, A.; Agathopoulos, S.; Valério, P.; Kannan, S.; Oktar, F.; Ferreira, J. Scaffolds for bone restoration from cuttlefish. Bone 2005, 37, 850-857. [CrossRef] [PubMed]

62. Rocha, J.; Lemos, A.; Kannan, S.; Agathopoulos, S.; Ferreira, J.M.F. Hydroxyapatite scaffolds hydrothermally grown from aragonitic cuttlefish bones. J. Mater. Chem. 2005, 15, 5007-5011. [CrossRef]

63. Gunduz, O.; Sahin, Y.; Agathopoulos, S.; Ben-Nissan, B.; Oktar, F.N. A new method for fabrication of nanohydroxyapatite and TCP from the sea snail Cerithium vulgatum. J. Nanomater. 2014, 2014, 382861. [CrossRef]

64. Kannan, S.; Rocha, J.H.; Agathopoulos, S.; Ferreira, J.M.F. Fluorine-substituted hydroxyapatite scaffolds hydrothermally grown from aragonitic cuttlefish bones. Acta Biomater. 2007, 3, 243-249. [CrossRef] [PubMed]

65. Predoi, D.; Iconaru, S.L.; Deniaud, A.; Chevallet, M.; Michaud-Soret, I.; Buton, N.; Prodan, A.M. Textural, structural and biological evaluation of hydroxyapatite doped with zinc at low concentrations. Materials 2017, 10, 229. [CrossRef] [PubMed]

66. Predoi, D.; Popa, C.L.; Chapon, P.; Groza, A.; Iconaru, S.L. Evaluation of the antimicrobial activity of different antibiotics enhanced with silver-doped hydroxyapatite thin films. Materials 2016, 9, 778. [CrossRef] [PubMed]

67. Vladescu, A.; Cotrut, C.M.; Azem, F.A.; Bramowicz, M.; Pana, I.; Braic, V.; Birlik, I.; Kiss, A.; Braic, M.; Abdulgader, R. Sputtered Si and Mg doped hydroxyapatite for biomedical applications. Biomed. Mater. 2018, 13, 025011. [CrossRef] [PubMed]

68. Vladescu, A.; Padmanabhan, S.; Azem, F.A.; Braic, M.; Titorencu, I.; Birlik, I.; Morris, M.; Braic, V. Mechanical properties and biocompatibility of the sputtered ti doped hydroxyapatite. J. Mech. Behav. Biomed. Mater. 2016, 63, 314-325. [CrossRef] [PubMed]

69. Ratnayake, J.T.B.; Mucalo, M.; Dias, G.J. Substituted hydroxyapatites for bone regeneration: A review of current trends. J. Biomed. Mater. Res. Part B 2017, 105, 1285-1299. [CrossRef] [PubMed]

70. Robinson, L.; Salma-Ancane, K.; Stipniece, L.; Meenan, B.J.; Boyd, A.R. The deposition of strontium and zinc co-substituted hydroxyapatite coatings. J. Mater. Sci. Mater. Med. 2017, 28, 51. [CrossRef] [PubMed]

71. Boanini, E.; Gazzano, M.; Bigi, A. Ionic substitutions in calcium phosphates synthesized at low temperature. Acta Biomater. 2010, 6, 1882-1894. [CrossRef] [PubMed] 
72. Sallam, S.M.; Tohami, K.M.; Sallam, A.M.; Salem, L.I.A.; Mohamed, F.A. Synthesis and characterization of hydroxyapatite contain chromium. J. Biophys. Chem. 2012, 3, 278-282. [CrossRef]

73. Golovanova, O.A.; Shlyapov, R.M.; Amerkhanova, S.K.; Uali, A.S.; Vlasov, V.A. Effect of cations $\left(\mathrm{Mg}^{2+}, \mathrm{Zn}^{2+}\right.$, $\left.\mathrm{Cd}^{2+}\right)$ on formation of the mineral phase in $\mathrm{Ca}\left(\mathrm{NO}_{3}\right)_{2}-\mathrm{Mg}\left(\mathrm{NO}_{3}\right)_{2}-\mathrm{Na}_{2} \mathrm{HPO}_{4}-\mathrm{H}_{2} \mathrm{O}$ system. IOP Conf. Ser. Mater. Sci. Eng. 2015, 81, 012065. [CrossRef]

74. Mishra, U. Development of Cobalt-Magnesium Doped Hydroxyapatite for Bone Tissue Engineering Application. Bachelor's Thesis, Department of Biotechnology and Medical Engineering, National Institute of Technology, Odisha, India, 2013.

75. Nandyala, S.H.; Santos, J.D. Current Trends on Glass and Ceramic Materials; Bentham Science Publishers: Sharjah, UAE, 2013; ISBN 978-1-60805-514-2.

76. Renaudin, G.; Gomes, S.; Nedelec, J.M. First-row transition metal doping in calcium phosphate bioceramics: A detailed crystallographic study. Materials 2017, 10, 92. [CrossRef] [PubMed]

77. Khanal, S.P.; Mahfuz, H.; Rondinone, A.J.; Leventouri, T. Improvement of the fracture toughness of hydroxyapatite (HAp) by incorporation of carboxyl functionalized single walled carbon nanotubes (CfSWCNTs) and nylon. Mater. Sci. Eng. C Mater. Biol. Appl. 2016, 60, 204-210. [CrossRef] [PubMed]

78. Uysal, I.; Severcan, F.; Tezcaner, A.; Evis, Z. Co-doping of hydroxyapatite with zinc and fluoride improves mechanical and biological properties of hydroxyapatite. Prog. Nat. Sci. 2014, 24, 340-349. [CrossRef]

79. Zyman, Z.; Tkachenko, M.; Epple, M.; Polyakov, M.; Naboka, M. Magnesium-substituted hydroxyapatite ceramics. Materialwiss. Werkstofftech. 2006, 37, 474-477. [CrossRef]

80. Lala, S.; Maity, T.; Singha, M.; Biswas, K.; Pradhan, S. Effect of doping (Mg, Mn, Zn) on the microstructure and mechanical properties of spark plasma sintered hydroxyapatites synthesized by mechanical alloying. Ceram. Int. 2017, 43, 2389-2397. [CrossRef]

81. Laskus, A.; Kolmas, J. Ionic substitutions in non-apatitic calcium phosphates. Int. J. Mol. Sci. 2017, 18, 2542. [CrossRef] [PubMed]

82. WHO Warns against 'Post-Antibiotic' Era. Nature. 30 April 2014. Available online: https://www.nature. com/news/who-warns-against-post-antibiotic-era-1.15135 (accessed on 12 October 2018).

83. World Health Organization. WHO's First Global Report on Antibiotic Resistance Reveals Serious, Worldwide Threat to Public Health. 2014. Available online: http:/ / www.who.int/mediacentre/news/releases/2014/ amr-report/en/ (accessed on 12 October 2018).

84. 14th Annual Report 2017. National Joint Registry. 2017. Available online: http://www.njrreports.org.uk/ (accessed on 12 October 2018).

85. Miculescu, F.; Bojin, D.; Ciocan, L.; Antoniac, I.; Miculescu, M.; Miculescu, N. Experimental researches on biomaterial-tissue interface interactions. J. Optoelectron. Adv. Mater. 2007, 9, 3303-3306.

86. Miculescu, F.; Ciocan, L.; Miculescu, M.; Ernuteanu, A. Effect of heating process on micro structure level of cortical bone prepared for compositional analysis. Dig. J. Nanomater. Biostruct. 2011, 6, 225-233.

87. Miculescu, F.; Jepu, I.; Lungu, C.; Miculescu, M.; Bane, M. Researches regarding the microanalysis results optimisation on multilayer nanostructures investigations. Dig. J. Nanomater. Biostruct. 2011, 6, 769-778.

88. Miculescu, F.; Mocanu, A.-C.; Dascalu, C.A.; Maidaniuc, A.; Batalu, D.; Berbecaru, A.; Voicu, S.I.; Miculescu, M.; Thakur, V.K.; Ciocan, L.T. Facile synthesis and characterization of hydroxyapatite particles for high value nanocomposites and biomaterials. Vacuum 2017, 146, 614-622. [CrossRef]

89. Duta, L.; Oktar, F.; Stan, G.; Popescu-Pelin, G.; Serban, N.; Luculescu, C.; Mihailescu, I. Novel doped hydroxyapatite thin films obtained by pulsed laser deposition. Appl. Surf. Sci. 2013, 265, 41-49. [CrossRef]

90. Commission Regulation (EU) No 722/2012. Off. J. Eur. Union 2012. Available online: https:/ / publications. europa.eu/en/publication-detail/-/publication/7fdb9dff-e222-11e1-905c-01aa75ed71a1 (accessed on 23 October 2018).

91. ISO 22442:2007-Medical Devices Utilizing Animal Tissues and Their Derivatives: Part 3. Validation of the Elimination and/or Inactivation of Viruses and Transmissible Spongiform Encephalopathy (TSE) Agents; ISO: Geneva, Switzerland, 2007.

92. Rincón-López, J.A.; Hermann-Muñoz, J.A.; Giraldo-Betancur, A.L.; De Vizcaya-Ruiz, A.; Alvarado-Orozco, J.M.; Muñoz-Saldaña, J. Synthesis, characterization and in vitro study of synthetic and bovine-derived hydroxyapatite ceramics: A comparison. Materials 2018, 11, 333. [CrossRef] [PubMed]

93. Bano, N.; Jikan, S.S.; Basri, H.; Bakar, S.A.A.; Nuhu, A.H. Natural hydroxyapatite extracted from bovine bone. J. Sci. Technol. 2017, 9, 22-28. 
94. Ramesh, S.; Loo, Z.Z.; Tan, C.Y.; Chew, W.J.K.; Ching, Y.C.; Tarlochan, F.; Chandran, H.; Krishnasamy, S.; Bang, L.T.; Sarhan, A.A.D. Characterization of biogenic hydroxyapatite derived from animal bones for biomedical applications. Ceram. Int. 2018, 44, 10525-10530. [CrossRef]

95. Rana, M.; Akhtar, N.; Rahman, S.; Jamil, H.; Asaduzzaman, S. Extraction of hydroxyapatite from bovine and human cortical bone by thermal decomposition and effect of gamma radiation: A comparative study. Int. J. Complement. Altern. Med. 2017, 8, 00263.

96. Goller, G.; Oktar, F.; Agathopoulos, S.; Tulyaganov, D.; Ferreira, J.; Kayali, E.; Peker, I. Effect of sintering temperature on mechanical and microstructural properties of bovine hydroxyapatite (BHA). J. Sol-Gel Sci. Technol. 2006, 37, 111-115. [CrossRef]

97. Mihailescu, N.; Stan, G.; Duta, L.; Chifiriuc, M.C.; Bleotu, C.; Sopronyi, M.; Luculescu, C.; Oktar, F.; Mihailescu, I. Structural, compositional, mechanical characterization and biological assessment of bovine-derived hydroxyapatite coatings reinforced with $\mathrm{MgF}_{2}$ or $\mathrm{MgO}$ for implants functionalization. Mater. Sci. Eng. C Mater. Biol. Appl. 2016, 59, 863-874. [CrossRef] [PubMed]

98. Popescu, A.; Florian, P.; Stan, G.; Popescu-Pelin, G.; Zgura, I.; Enculescu, M.; Oktar, F.; Trusca, R.; Sima, L.; Roseanu, A. Physical-chemical characterization and biological assessment of simple and lithium-doped biological-derived hydroxyapatite thin films for a new generation of metallic implants. Appl. Surf. Sci. 2018, 439, 724-735. [CrossRef]

99. Ofudje, E.A.; Rajendran, A.; Adeogun, A.I.; Idowu, M.A.; Kareem, S.O.; Pattanayak, D.K. Synthesis of organic derived hydroxyapatite scaffold from pig bone waste for tissue engineering applications. Adv. Powder Technol. 2018, 29, 1-8. [CrossRef]

100. Ramirez-Gutierrez, C.F.; Londoño-Restrepo, S.M.; del Real, A.; Mondragón, M.A.; Rodriguez-García, M.E. Effect of the temperature and sintering time on the thermal, structural, morphological, and vibrational properties of hydroxyapatite derived from pig bone. Ceram. Int. 2017, 43, 7552-7559. [CrossRef]

101. Sobczak-Kupiec, A.; Pluta, K.; Drabczyk, A.; Włoś, M.; Tyliszczak, B. Synthesis and characterization of ceramic-polymer composites containing bioactive synthetic hydroxyapatite for biomedical applications. Ceram. Int. 2018, 44, 13630-13638. [CrossRef]

102. Jaber, H.L.; Hammood, A.S.; Parvin, N. Synthesis and characterization of hydroxyapatite powder from natural Camelus bone. J. Aust. Ceram. Soc. 2017, 54, 1-10. [CrossRef]

103. Ekren, N. Reinforcement of sheep-bone derived hydroxyapatite with bioactive glass. J. Ceram. Process. Res. 2017, 18, 64-68.

104. Karacayli, U.; Gunduz, O.; Salman, S.; Ozyegin, L.; Agathopoulos, S.; Oktar, F. Effect of sintering temperature on mechanical properties and microstructure of sheep-bone derived hydroxyapatite (SHA). In Proceedings of the 13th International Conference on Biomedical Engineering, Munich, Germany, 7-12 September 2009; pp. 1271-1274. [CrossRef]

105. Duta, L.; Mihailescu, N.; Popescu, A.; Luculescu, C.; Mihailescu, I.; Çetin, G.; Gunduz, O.; Oktar, F.; Popa, A.; Kuncser, A. Comparative physical, chemical and biological assessment of simple and titanium-doped ovine dentine-derived hydroxyapatite coatings fabricated by pulsed laser deposition. Appl. Surf. Sci. 2017, 413, 129-139. [CrossRef]

106. Alshemary, A.Z.; Akram, M.; Taha, A.; Tezcaner, A.; Evis, Z.; Hussain, R. Physico-chemical and biological properties of hydroxyapatite extracted from chicken beaks. Mater. Lett. 2018, 215, 169-172. [CrossRef]

107. Zhu, H.; Song, W.; Deng, Y. Hydroxyapatite extracted by animal bone image analysis in ionic liquid choline chloride-glycerol. EURASIP J. Image Video Process. 2018, 2018, 56. [CrossRef]

108. Elkayar, A.; Elshazly, Y.; Assaad, M. Properties of hydroxyapatite from bovine teeth. Bone Tissue Regen. Insights 2009, 2, 31-36. [CrossRef]

109. Akyurt, N.; Yetmez, M.; Karacayli, U.; Gunduz, O.; Agathopoulos, S.; Gökçe, H.; Öveçoğlu, M.; Oktar, F. A new natural biomaterial: Sheep dentine derived hydroxyapatite. Key Eng. Mater. 2012, 493-494, 281-286. [CrossRef]

110. Roudan, M.A.; Ramesh, S.; Niakan, A.; Wong, Y.; Zavareh, M.A.; Chandran, H.; Teng, W.; Lwin, N.; Sutharsini, U. Thermal phase stability and properties of hydroxyapatite derived from bio-waste eggshells. J. Ceram. Process. Res. 2017, 18, 69-72.

111. Cahyanto, A.; Kosasih, E.; Aripin, D.; Hasratiningsih, Z. Fabrication of hydroxyapatite from fish bones waste using reflux method. IOP Conf. Ser. Mater. Sci. Eng. 2017, 172, 012006. [CrossRef] 
112. Sunil, B.R.; Jagannatham, M. Producing hydroxyapatite from fish bones by heat treatment. Mater. Lett. 2016, 185, 411-414. [CrossRef]

113. Walsh, P.J.; Buchanan, F.J.; Dring, M.; Maggs, C.; Bell, S.; Walker, G.M. Low-pressure synthesis and characterisation of hydroxyapatite derived from mineralise red algae. Chem. Eng. J. 2008, 137, 173-179. [CrossRef]

114. Yelten, A.; Yilmaz, S. Comparison of naturally and synthetically derived hydroxyapatite powders. Acta Phys. Pol. A 2017, 131, 55-58. [CrossRef]

115. Balaz, M. Ball milling of eggshell waste as a green and sustainable approach: A review. Adv. Colloid Interface Sci. 2018, 256, 256-275. [CrossRef] [PubMed]

116. Antoniac, I.V.; Lesci, I.G.; Blajan, A.I.; Vitioanu, G.; Antoniac, A. Bioceramics and biocomposites from marine sources. Key Eng. Mater. 2016, 672, 276-292. [CrossRef]

117. Granito, R.N.; Renno, A.C.M.; Yamamura, H.; de Almeida, M.C.; Ruiz, P.L.M.; Ribeiro, D.A. Hydroxyapatite from fish for bone tissue engineering: A promising approach. Int. J. Mol. Cell. Med. 2018, 7, 80-90. [CrossRef] [PubMed]

118. Inan, A.; Komur, B.; Ekren, N.; Aydogdu, M.; Gokce, H.; Ficai, A.; Salman, S.; Oktar, F.; Gunduz, O. Physical characterization of Turbot (Psetta Maxima) originated natural hydroxyapatite. Acta Phys. Pol. A 2017, 131, 397-399. [CrossRef]

119. Abdulrahman, I.; Tijani, H.I.; Mohammed, B.A.; Saidu, H.; Yusuf, H.; Ndejiko Jibrin, M.; Mohammed, S. From garbage to biomaterials: An overview on egg shell based hydroxyapatite. J. Mater. 2014, 2014, 802467. [CrossRef]

120. Ronan, K.; Kannan, M.B. Novel sustainable route for synthesis of hydroxyapatite biomaterial from biowastes. ACS Sustain. Chem. Eng. 2017, 5, 2237-2245. [CrossRef]

121. Wu, S.-C.; Hsu, H.-C.; Hsu, S.-K.; Chang, Y.-C.; Ho, W.-F. Synthesis of hydroxyapatite from eggshell powders through ball milling and heat treatment. J. Asian Ceram. Soc. 2016, 4, 85-90. [CrossRef]

122. Büdinger, L.; Hertl, M.; Büdinger, L. Immunologic mechanisms in hypersensitivity reactions to metal ions: An overview. Allergy 2000, 55, 108-115. [CrossRef] [PubMed]

123. Kaygili, O.; Dorozhkin, S.V.; Keser, S. Synthesis and characterization of Ce-substituted hydroxyapatite by sol-gel method. Mater. Sci. Eng. C Biol. Appl. 2014, 42, 78-82. [CrossRef] [PubMed]

124. Kaygili, O.; Keser, S.; Bulut, N.; Ates, T. Characterization of Mg-containing hydroxyapatites synthesized by combustion method. Physica B 2018, 537, 63-67. [CrossRef]

125. Kolmas, J.; Groszyk, E.; Kwiatkowska-Rozycka, D. Substituted hydroxyapatites with antibacterial properties. BioMed Res. Int. 2014, 2014, 178123. [CrossRef] [PubMed]

126. Perera, T.S.H.; Han, Y.; Lu, X.; Wang, X.; Dai, H.; Li, S. Rare earth doped apatite nanomaterials for biological application. J. Nanomater. 2015, 2015, 705390. [CrossRef]

127. Sadat-Shojai, M.; Khorasani, M.-T.; Dinpanah-Khoshdargi, E.; Jamshidi, A. Synthesis methods for nanosized hydroxyapatite with diverse structures. Acta Biomater. 2013, 9, 7591-7621. [CrossRef] [PubMed]

128. Li, Y.; Ooi, C.P.; Philip Hong Ning, C.; Aik Khor, K. Synthesis and characterization of Neodymium(III) and Gadolinium(III)-substituted hydroxyapatite as biomaterials. Int. J. Appl. Ceram. Technol. 2009, 6, 501-512. [CrossRef]

129. Wang, P.; Li, C.; Gong, H.; Jiang, X.; Wang, H.; Li, K. Effects of synthesis conditions on the morphology of hydroxyapatite nanoparticles produced by wet chemical process. Powder Technol. 2010, 203, 315-321. [CrossRef]

130. Rh Owen, G.; Dard, M.; Larjava, H. Hydoxyapatite/beta-tricalcium phosphate biphasic ceramics as regenerative material for the repair of complex bone defects. J. Biomed. Mater. Res. Part B 2018, 106, 2493-2512. [CrossRef] [PubMed]

131. Surmenev, R.A. A review of plasma-assisted methods for calcium phosphate-based coatings fabrication. Surf. Coat. Technol. 2012, 206, 2035-2056. [CrossRef]

132. Durham, J.W.; Montelongo, S.A.; Ong, J.L.; Guda, T.; Allen, M.J.; Rabiei, A. Hydroxyapatite coating on PEEK implants: Biomechanical and histological study in a rabbit model. Mater. Sci. Eng. C Mater. Biol. Appl. 2016, 68, 723-731. [CrossRef] [PubMed]

133. Bono, J.V.; McCarthy, J.C.; Thornhill, T.S.; Bierbaum, B.E.; Turner, R.H. Revision Total Hip Arthroplasty; Springer: Berlin, Germany, 1999; ISBN 978-1-4612-1406-9. 
134. Epinette, J.-A.; Manley, M.T. Fifteen Years of Clinical Experience with Hydroxyapatite Coatings in Joint Arthroplasty; Springer: Berlin, Germany, 2013; ISBN 978-2-8178-0851-2.

135. Graziani, G.; Bianchi, M.; Sassoni, E.; Russo, A.; Marcacci, M. Ion-substituted calcium phosphate coatings deposited by plasma-assisted techniques: A review. Mater. Sci. Eng. C Mater. Biol. Appl. 2017, 74, 219-229. [CrossRef] [PubMed]

136. Vilardell, A.M.; Cinca, N.; Jokinen, A.; Garcia-Giralt, N.; Dosta, S.; Cano, I.G.; Guilemany, J.M. Real-time protein and cell binding measurements on hydroxyapatite coatings. J. Funct. Biomater. 2016, 7, 23. [CrossRef] [PubMed]

137. Domínguez-Trujillo, C.; Peón, E.; Chicardi, E.; Pérez, H.; Rodríguez-Ortiz, J.A.; Pavón, J.J.; García-Couce, J.; Galván, J.; García-Moreno, F.; Torres, Y. Sol-gel deposition of hydroxyapatite coatings on porous titanium for biomedical applications. Surf. Coat. Technol. 2018, 333, 158-162. [CrossRef]

138. Stoica, T.; Morosanu, C.; Slav, A.; Stoica, T.; Osiceanu, P.; Anastasescu, C.; Gartner, M.; Zaharescu, M. Hydroxyapatite films obtained by sol-gel and sputtering. Thin Solid Films 2008, 516, 8112-8116. [CrossRef]

139. Đošić, M.; Eraković, S.; Janković, A.; Vukašinović-Sekulić, M.; Matić, I.Z.; Stojanović, J.; Rhee, K.Y.; Mišković-Stanković, V.; Park, S.-J. In vitro investigation of electrophoretically deposited bioactive hydroxyapatite/chitosan coatings reinforced by graphene. J. Ind. Eng. Chem. 2017, 47, 336-347. [CrossRef]

140. Dudek, K.; Dulski, M.; Goryczka, T.; Gerle, A. Structural changes of hydroxyapatite coating electrophoretically deposited on NiTi shape memory alloy. Ceram. Int. 2018, 44, 11292-11300. [CrossRef]

141. Chakraborty, R.; Saha, P. A comparative study on surface morphology and electrochemical behaviour of hydroxyapatite-calcium hydrogen phosphate composite coating synthesized in-situ through electro chemical process under various deposition conditions. Surf. Interfaces 2018, 12, 160-167. [CrossRef]

142. El-Wassefy, N.; Reicha, F.; Aref, N. Electro-chemical deposition of nano hydroxyapatite-zinc coating on titanium metal substrate. Int. J. Implant Dent. 2017, 3, 39. [CrossRef] [PubMed]

143. Sandukas, S.; Yamamoto, A.; Rabiei, A. Osteoblast adhesion to functionally graded hydroxyapatite coatings doped with silver. J. Biomed. Mater. Res. Part A 2011, 97, 490-497. [CrossRef] [PubMed]

144. Aktug, S.L.; Kutbay, I.; Usta, M. Characterization and formation of bioactive hydroxyapatite coating on commercially pure zirconium by micro arc oxidation. J. Alloys Compd. 2017, 695, 998-1004. [CrossRef]

145. Tang, H.; Gao, Y. Preparation and characterization of hydroxyapatite containing coating on AZ31 magnesium alloy by micro-arc oxidation. J. Alloys Compd. 2016, 688, 699-708. [CrossRef]

146. Fatehi, K.; Moztarzadeh, F.; Solati-Hashjin, M.; Tahriri, M.; Rezvannia, M.; Ravarian, R. In vitro biomimetic deposition of apatite on alkaline and heat treated Ti6A14V alloy surface. Bull. Mat. Sci. 2008, 31, 101. [CrossRef]

147. Iijima, K.; Sakai, A.; Komori, A.; Sakamoto, Y.; Matsuno, H.; Serizawa, T.; Hashizume, M. Control of biomimetic hydroxyapatite deposition on polymer substrates using different protein adsorption abilities. Colloid Surf. B Biointerfaces 2015, 130, 77-83. [CrossRef] [PubMed]

148. Pylypchuk, I.V.; Petranovskaya, A.; Gorbyk, P.; Korduban, A.; Markovsky, P.; Ivasishin, O. Biomimetic hydroxyapatite growth on functionalized surfaces of Ti-6Al-4V and Ti-Zr-Nb Alloys. Nanoscale Res. Lett. 2015, 10, 338. [CrossRef] [PubMed]

149. Ivanova, A.; Surmeneva, M.; Tyurin, A.; Surmenev, R. Correlation between structural and mechanical properties of RF magnetron sputter deposited hydroxyapatite coating. Mater. Charact. 2018, 142, 261-269. [CrossRef]

150. Monsees, T.; Ak Azem, F.; Cotrut, C.; Braic, M.; Abdulgader, R.; Pana, I.; Birlik, I.; Kiss, A.; Booysen, R.; Vladescu, A. Biodegradable ceramics consisting of hydroxyapatite for orthopaedic implants. Coatings 2017, 7, 184. [CrossRef]

151. Stan, G.E. Adherent functional graded hydroxylapatite coatings produced by sputtering deposition techniques. J. Optoelectron. Adv. Mater. 2009, 11, 1132-1138.

152. Bianchi, M.; Degli Esposti, L.; Ballardini, A.; Liscio, F.; Berni, M.; Gambardella, A.; Leeuwenburgh, S.C.; Sprio, S.; Tampieri, A.; Iafisco, M. Strontium doped calcium phosphate coatings on poly (etheretherketone) (PEEK) by pulsed electron deposition. Surf. Coat. Technol. 2017, 319, 191-199. [CrossRef]

153. Bianchi, M.; Gambardella, A.; Graziani, G.; Liscio, F.; Maltarello, M.C.; Boi, M.; Berni, M.; Bellucci, D.; Marchiori, G.; Valle, F. Plasma-assisted deposition of bone apatite-like thin films from natural apatite. Mater. Lett. 2017, 199, 32-36. [CrossRef] 
154. Bianchi, M.; Pisciotta, A.; Bertoni, L.; Berni, M.; Gambardella, A.; Visani, A.; Russo, A.; De Pol, A.; Carnevale, G. Osteogenic differentiation of hDPSCs on biogenic bone apatite thin films. Stem Cells Int. 2017, 2017, 3579283. [CrossRef] [PubMed]

155. Graziani, G.; Carnevale, G.; Pisciotta, A.; Bertoni, L.; Boi, M.; Gambardella, A.; Berni, M.; Marchiori, G.; Russo, A.; De Pol, A. Pulsed electron deposition of bone-like apatite thin films from a biogenic source: From material characterization to in vitro stem cell differentiation. Orthop. Proc. 2018, 100, 1.

156. Boanini, E.; Torricelli, P.; Sima, F.; Axente, E.; Fini, M.; Mihailescu, I.N.; Bigi, A. Gradient coatings of strontium hydroxyapatite/zinc $\beta$-tricalcium phosphate as a tool to modulate osteoblast/osteoclast response. J. Inorg. Biochem. 2018, 183, 1-8. [CrossRef] [PubMed]

157. Janković, A.; Eraković, S.; Ristoscu, C.; Mihailescu, N.; Duta, L.; Visan, A.; Stan, G.; Popa, A.; Husanu, M.; Luculescu, C. Structural and biological evaluation of lignin addition to simple and silver-doped hydroxyapatite thin films synthesized by matrix-assisted pulsed laser evaporation. J. Mater. Sci. Mater. Med. 2015, 26, 17. [CrossRef] [PubMed]

158. Popescu-Pelin, G.; Sima, F.; Sima, L.; Mihailescu, C.; Luculescu, C.; Iordache, I.; Socol, M.; Socol, G.; Mihailescu, I. Hydroxyapatite thin films grown by pulsed laser deposition and matrix assisted pulsed laser evaporation: Comparative study. Appl. Surf. Sci. 2017, 418, 580-588. [CrossRef]

159. Visan, A.; Stan, G.E.; Ristoscu, C.; Popescu-Pelin, G.; Sopronyi, M.; Besleaga, C.; Luculescu, C.; Chifiriuc, M.C.; Hussien, M.; Marsan, O. Combinatorial MAPLE deposition of antimicrobial orthopedic maps fabricated from chitosan and biomimetic apatite powders. Int. J. Pharm. 2016, 511, 505-515. [CrossRef] [PubMed]

160. Bosco, R.; Van Den Beucken, J.; Leeuwenburgh, S.; Jansen, J. Surface engineering for bone implants: A trend from passive to active surfaces. Coatings 2012, 2, 95-119. [CrossRef]

161. Narayanan, R.; Seshadri, S.K.; Kwon, T.Y.; Kim, K.H. Calcium phosphate-based coatings on titanium and its alloys. J. Biomed. Mater. Res. Part B 2008, 85, 279-299. [CrossRef] [PubMed]

162. Hontsu, S.; Nakamoru, M.; Nishikawa, H.; Kusunoki, M. Characteristics of a humidity sensor using a Na-doped hydroxyapatite thin film. Mem. Fac. Biol.-Oriented Sci. Technol. Kinki Univ. 2010, 26, 87-91.

163. Essamlali, Y.; Amadine, O.; Larzek, M.; Len, C.; Zahouily, M. Sodium modified hydroxyapatite: Highly efficient and stable solid-base catalyst for biodiesel production. Energy Conv. Manag. 2017, 149, 355-367. [CrossRef]

164. Sugiyama, S.; Iguchi, Y.; Nishioka, H.; Minami, T.; Moriga, T.; Hayashi, H.; Moffat, J.B. Effects of the thermal stability and the fine structure changes of strontium hydroxyapatites ion-exchanged with lead on methane oxidation in the presence and absence of tetrachloromethane. J. Catal. 1998, 176, 25-34. [CrossRef]

165. Fierascu, I.; Avramescu, S.M.; Petreanu, I.; Marinoiu, A.; Soare, A.; Nica, A.; Fierascu, R.C. Efficient removal of phenol from aqueous solutions using hydroxyapatite and substituted hydroxyapatites. React. Kinet. Mech. Catal. 2017, 122, 155-175. [CrossRef]

166. Sugiyama, S.; Shono, T.; Nitta, E.; Hayashi, H. Effects of gas- and solid-phase additives on oxidative dehydrogenation of propane on strontium and barium hydroxyapatites. Appl. Catal. A Gen. 2001, 211, 123-130. [CrossRef]

167. Chen, Z.; Liu, Y.; Mao, L.; Gong, L.; Sun, W.; Feng, L. Effect of cation doping on the structure of hydroxyapatite and the mechanism of defluoridation. Ceram. Int. 2018, 44, 6002-6009. [CrossRef]

168. Nie, Y.; Hu, C.; Kong, C. Enhanced fluoride adsorption using Al(III) modified calcium hydroxyapatite. J. Hazard. Mater. 2012, 233-234, 194-199. [CrossRef] [PubMed]

169. Thom, N.T.; Thanh, D.T.M.; Nam, P.T.; Phuong, N.T.; Hong, C.T.; Xuyen, N.T.; Van Trang, N.; Buess-Herman, C. Treatment of $\mathrm{Cd}^{2+}$ ions using aluminum doped hydroxyapatite (AlHAp) powder. Viet. J. Chem. 2017, 55, 393-399. [CrossRef]

170. Rahmanian, A.; Ghaziaskar, H.S. Continuous dehydration of ethanol to diethyl ether over aluminum phosphate-hydroxyapatite catalyst under sub and supercritical condition. J. Supercrit. Fluids 2013, 78, 34-41. [CrossRef]

171. Neidel, L.L.; Moore, R.C.; Salas, F.; Grouios, F.; Holt, K.C.; Helean, K.B. Sequestration of radionuclides and heavy metals by hydroxyapatite doped with Fe, $\mathrm{Cu}$ and Sn. Geochim. Cosmochim. Acta 2005, 69, A70. [CrossRef]

172. Matsumura, Y.; Moffat, J.B.; Sugiyama, S.; Hayashi, H.; Shigemoto, N.; Saitoh, K. Selective oxidative coupling of methane catalysed over hydroxyapatite ion-exchanged with lead. J. Chem. Soc. Faraday Trans. 1994, 90, 2133-2140. [CrossRef] 
173. Oh, S.C.; Xu, J.; Tran, D.T.; Liu, B.; Liu, D. Effects of controlled crystalline surface of hydroxyapatite on methane oxidation reactions. ACS Catal. 2018, 8, 4493-4507. [CrossRef]

174. Wei, X.; Yates, M.Z. Yttrium-doped hydroxyapatite membranes with high proton conductivity. Chem. Mater. 2012, 24, 1738-1743. [CrossRef]

175. Hu, A.; Li, M.; Chang, C.; Mao, D. Preparation and characterization of a titanium-substituted hydroxyapatite photocatalyst. J. Mol. Catal. A Chem. 2007, 267, 79-85. [CrossRef]

176. Salhi, A.; Aarfane, A.; Tahiri, S.; Khamliche, L.; Bensitel, M.; Bentiss, F.; El Krati, M. Study of the photocatalytic degradation of methylene blue dye using titanium-doped hydroxyapatite. Mediterr. J. Chem. 2015, 4, 59-67. [CrossRef]

177. Wakamura, M.; Hashimoto, K.; Watanabe, T. Photocatalysis by calcium hydroxyapatite modified with Ti(IV): Albumin decomposition and bactericidal effect. Langmuir 2003, 19, 3428-3431. [CrossRef]

178. Nishikawa, M.; Tan, L.H.; Nakabayashi, Y.; Hasegawa, T.; Shiroishi, W.; Kawahara, S.; Saito, N.; Nosaka, A.; Nosaka, Y. Visible light responsive vanadium-substituted hydroxyapatite photocatalysts. J. Photochem. Photobiol. A Chem. 2015, 311, 30-34. [CrossRef]

179. Chlala, D.; Griboval-Constant, A.; Nuns, N.; Giraudon, J.M.; Labaki, M.; Lamonier, J.F. Effect of Mn loading onto hydroxyapatite supported Mn catalysts for toluene removal: Contribution of PCA assisted ToF-SIMS. Catal. Today 2018, 307, 41-47. [CrossRef]

180. Ravindranadh, K.; Babu, B.; Pushpa Manjari, V.; Thirumala Rao, G.; Rao, M.C.; Ravikumar, R.V.S.S.N. Optical and structural properties of undoped and $\mathrm{Mn}^{2+}$ doped $\mathrm{Ca}-\mathrm{Li}$ hydroxyapatite nanopowders using mechanochemical synthesis. J. Lumines. 2015, 159, 119-127. [CrossRef]

181. Kanchana, P.; Radhakrishnan, S.; Navaneethan, M.; Arivanandhan, M.; Hayakawa, Y.; Sekar, C. Electrochemical sensor based on fe doped hydroxyapatite-carbon nanotubes composite for l-dopa detection in the presence of uric acid. J. Nanosci. Nanotechnol. 2016, 16, 6185-6192. [CrossRef] [PubMed]

182. Khachani, M.; Kacimi, M.; Ensuque, A.; Piquemal, J.-Y.; Connan, C.; Bozon-Verduraz, F.; Ziyad, M. Iron-calcium-hydroxyapatite catalysts: Iron speciation and comparative performances in butan-2-ol conversion and propane oxidative dehydrogenation. Appl. Catal. A Gen. 2010, 388, 113-123. [CrossRef]

183. Padayachee, D.; Dasireddy, V.D.B.C.; Bharuth-Ram, K.; Singh, S.; Friedrich, H.B. Phase transformation of iron in hydroxyapatite in the activation of n-octane. Hyperfine Interact. 2014, 231, 131-136. [CrossRef]

184. Mene, R.U.; Mahabole, M.P.; Khairnar, R. Surface modification of cobalt doped hydroxyapatite thick films via swift heavy ion irradiations for $\mathrm{CO}$ and $\mathrm{CO}_{2}$ gas sensing application. In Proceedings of the 14th International Meeting on Chemical Sensors (IMCS 2012), Nuremberg, Germany, 20-23 May 2012; pp. 1180-1183. [CrossRef]

185. Emayavaramban, P.; Babu, S.G.; Karvembu, R.; Dharmaraj, N. Nickel oxide doped hydroxyapatite for catalytic oxidation of alcohols to carbonyl compounds at room temperature. Adv. Sci. Eng. Med. 2014, 6, 659-666. [CrossRef]

186. Miniach, E.; Śliwak, A.; Moyseowicz, A.; Gryglewicz, G. Growth of carbon nanofibers from methane on a hydroxyapatite-supported nickel catalyst. J. Mater. Sci. 2016, 51, 5367-5376. [CrossRef]

187. Neelakandeswari, N.; Sangami, G.; Emayavaramban, P.; Karvembu, R.; Dharmaraj, N.; Kim, H.Y. Mesoporous nickel hydroxyapatite nanocomposite for microwave-assisted Henry reaction. Tetrahedron Lett. 2012, 53, 2980-2984. [CrossRef]

188. Rego de Vasconcelos, B.; Pham Minh, D.; Sharrock, P.; Nzihou, A. Regeneration study of Ni/hydroxyapatite spent catalyst from dry reforming. Catal. Today 2018, 310, 107-115. [CrossRef]

189. Kamieniak, J.; Bernalte, E.; Foster, C.; Doyle, A.; Kelly, P.; Banks, C. High yield synthesis of hydroxyapatite (HAP) and palladium doped HAP via a wet chemical synthetic route. Catalysts 2016, 6, 119. [CrossRef]

190. Kamieniak, J.; Kelly, P.J.; Doyle, A.M.; Banks, C.E. Influence of the metal/metal oxide redox cycle on the catalytic activity of methane oxidation over Pd and Ni doped hydroxyapatite. Catal. Commun. 2018, 107, 82-86. [CrossRef]

191. Takarroumt, N.; Kacimi, M.; Bozon-Verduraz, F.; Liotta, L.F.; Ziyad, M. Characterization and performance of the bifunctional platinum-loaded calcium-hydroxyapatite in the one-step synthesis of methyl isobutyl ketone. J. Mol. Catal. A Chem. 2013, 377, 42-50. [CrossRef]

192. Vukomanović, M.; Žunič, V.; Otoničar, M.; Repnik, U.; Turk, B.; Škapin, S.D.; Suvorov, D. Hydroxyapatite/ platinum bio-photocatalyst: A biomaterial approach to self-cleaning. J. Mater. Chem. 2012, 22, 10571-10580. [CrossRef] 
193. Chlala, D.; Giraudon, J.M.; Nuns, N.; Labaki, M.; Lamonier, J.F. Highly active noble-metal-free copper hydroxyapatite catalysts for the total oxidation of toluene. Chem CatChem 2017, 9, 2275-2283. [CrossRef]

194. Guo, J.; Yu, H.; Dong, F.; Zhu, B.; Huang, W.; Zhang, S. High efficiency and stability of Au-Cu/hydroxyapatite catalyst for the oxidation of carbon monoxide. RSC Adv. 2017, 7, 45420-45431. [CrossRef]

195. Othmani, M.; Bachoua, H.; Ghandour, Y.; Aissa, A.; Debbabi, M. Synthesis, characterization and catalytic properties of copper-substituted hydroxyapatite nanocrystals. Mater. Res. Bull. 2018, 97, 560-566. [CrossRef]

196. Tounsi, H.; Djemal, S.; Petitto, C.; Delahay, G. Copper loaded hydroxyapatite catalyst for selective catalytic reduction of nitric oxide with ammonia. Appl. Catal. B Environ. 2011, 107, 158-163. [CrossRef]

197. Jahan, S.A.; Mollah, M.Y.A.; Ahmed, S.; Susan, M.A.B.H. Copper-doped hydroxyapatite for removal of Arsenic(V) from aqueous system. J. Sci. Res. 2017, 9, 383-402. [CrossRef]

198. Kumar, P.A.; Reddy, M.P.; Ju, L.K.; Phil, H.H. Novel silver loaded hydroxyapatite catalyst for the selective catalytic reduction of $\mathrm{NO}_{x}$ by propene. Catal. Lett. 2008, 126, 78-83. [CrossRef]

199. Mitsudome, T.; Mikami, Y.; Mori, H.; Arita, S.; Mizugaki, T.; Jitsukawa, K.; Kaneda, K. Supported silver nanoparticle catalyst for selective hydration of nitriles to amides in water. Chem. Commun. 2009, 0, 3258-3260. [CrossRef] [PubMed]

200. Xu, J.; Xu, X.-C.; Yang, X.-J.; Han, Y.-F. Silver/hydroxyapatite foam as a highly selective catalyst for acetaldehyde production via ethanol oxidation. Catal. Today 2016, 276, 19-27. [CrossRef]

201. Domínguez, M.I.; Romero-Sarria, F.; Centeno, M.A.; Odriozola, J.A. Gold/hydroxyapatite catalysts: Synthesis, characterization and catalytic activity to CO oxidation. Appl. Catal. B Environ. 2009, 87, 245-251. [CrossRef]

202. Phonthammachai, N.; Ziyi, Z.; Jun, G.; Fan, H.Y.; Whitea, T. Synthesis of high performance hydroxyapatite-gold catalysts for CO oxidation. Gold Bull. 2008, 41, 42-50. [CrossRef]

203. Lakshmi Kantam, M.; Balasubrahmanyam, V.; Kumar, K.S. Zinc hydroxyapatite-catalyzed efficient synthesis of 5-substituted 1 H-tetrazoles. Synth. Commun. 2006, 36, 1809-1814. [CrossRef]

204. Low, H.R.; Avdeev, M.; Ramesh, K.; White, T.J. Zinc hydroxyapatite catalyst for decomposition of 2-propanol. Adv. Mater. 2012, 24, 4175-4179. [CrossRef] [PubMed]

205. Riad, M.; Mikhail, S. Zinc incorporated hydroxyapatite catalysts: Preparation and characterization. Energy Sources Part A Recover. Util. Environ. Eff. 2013, 35, 445-454. [CrossRef]

206. Latshaw, A.M.; Hughey, K.D.; Smith, M.D.; Yeon, J.; Zur Loye, H.C. Photoluminescent and magnetic properties of lanthanide containing apatites: $\mathrm{Na}_{\mathrm{x}} \mathrm{Ln}_{10-\mathrm{x}}\left(\mathrm{SiO}_{4}\right)_{6} \mathrm{O}_{2-\mathrm{y}} \mathrm{F}_{\mathrm{y}}, \mathrm{Ca}_{\mathrm{x}} \mathrm{Ln}_{10-\mathrm{x}}\left(\mathrm{SiO}_{4}\right)_{6} \mathrm{O}_{2-\mathrm{y}} \mathrm{F}_{\mathrm{y}}(\mathrm{Ln}=\mathrm{Eu}$, $\mathrm{Gd}$, and $\mathrm{Sm}), \mathrm{Gd}_{9.34}\left(\mathrm{SiO}_{4}\right)_{6} \mathrm{O}_{2}$, and $\mathrm{K}_{1.32} \mathrm{Pr}_{8.68}\left(\mathrm{SiO}_{4}\right)_{6} \mathrm{O}_{1.36} \mathrm{~F}_{0.64}$. Inorg. Chem. 2015, 54, 876-884. [CrossRef] [PubMed]

207. Kottaisamy, M.; Jagannathan, R.; Jeyagopal, P.; Rao, R.; Narayanan, R. Eu ${ }^{2+}$ luminescence in $\mathrm{M}_{5}\left(\mathrm{PO}_{4}\right)_{3} \mathrm{X}$ apatites, where $\mathrm{M}$ is $\mathrm{Ca}^{2+}, \mathrm{Sr}^{2+}$ and $\mathrm{Ba}^{2+}$, and $\mathrm{X}$ is $\mathrm{F}^{-}, \mathrm{Cl}^{-}, \mathrm{Br}^{-}$and $\mathrm{OH}^{-}$. J. Phys. D Appl. Phys. 1994, 27, 2210. [CrossRef]

208. Constantin, L.; Iconaru, S.; Ciobanu, C. Europium doped hydroxyapatite for applications in environmental field. Rom. Rep. Phys. 2012, 64, 788-794.

209. Jiménez-Flores, Y.; Suárez-Quezada, M.; Rojas-Trigos, J.B.; Lartundo-Rojas, L.; Suárez, V.; Mantilla, A. Characterization of Tb-doped hydroxyapatite for biomedical applications: Optical properties and energy band gap determination. J. Mater. Sci. 2017, 52, 9990-10000. [CrossRef]

210. Zhang, Z.H.; Wang, H.; Chen, L.; Guo, D.X.; Cai, K.Q.; Liu, X.J.; Huang, Z.L. Synthesis of $\mathrm{Tb}^{3+}$-doped Ca-deficient hydroxyapatite and its photoluminescence for white light-emitting diode application. Adv. Mater. Res. 2012, 560-561, 825-829. [CrossRef]

211. Zhang, Y.; Mei, L.; Liu, H.; Yang, D.; Liao, L.; Huang, Z. Dysprosium doped novel apatite-type white-emitting phosphor $\mathrm{Ca} 9 \mathrm{La}\left(\mathrm{PO}_{4}\right)_{5}\left(\mathrm{GeO}_{4}\right) \mathrm{F}_{2}$ with satisfactory thermal properties for n-UV w-LEDs. Dyes Pigments 2017, 139, 180-186. [CrossRef]

212. Hager, E.; Dziambor, H.; Höhmann, D.; Winkler, P.; Strama, H. Effects of lithium on thrombopoiesis in patients with low platelet cell counts following chemotherapy or radiotherapy. Biol. Trace Elem. Res. 2001, 83, 139-148. [CrossRef]

213. Hager, E.D.; Dziambor, H.; Winkler, P.; Hohmann, D.; Macholdt, K. Effects of lithium carbonate on hematopoietic cells in patients with persistent neutropenia following chemotherapy or radiotherapy. J. Trace Elem. Med. Biol. 2002, 16, 91-97. [CrossRef] 
214. Levitt, L.J.; Quesenberry, P.J. The effect of lithium on murine hematopoiesis in a liquid culture system. N. Engl. J. Med. 1980, 302, 713-719. [CrossRef] [PubMed]

215. Klontzas, M.E.; Kenanidis, E.I.; MacFarlane, R.J.; Michail, T.; Potoupnis, M.E.; Heliotis, M.; Mantalaris, A.; Tsiridis, E. Investigational drugs for fracture healing: Preclinical \& clinical data. Expert Opin. Investig. Drugs 2016, 25, 585-596. [CrossRef] [PubMed]

216. Bernick, J.; Wang, Y.; Sigal, I.A.; Alman, B.A.; Whyne, C.M.; Nam, D. Parameters for lithium treatment are critical in its enhancement of fracture-healing in rodents. J. Bone Jt. Surg. Am. Vol. 2014, 96, 1990-1998. [CrossRef] [PubMed]

217. Chen, Y.; Whetstone, H.C.; Lin, A.C.; Nadesan, P.; Wei, Q.; Poon, R.; Alman, B.A. Beta-catenin signaling plays a disparate role in different phases of fracture repair: Implications for therapy to improve bone healing. PLoS Med. 2007, 4, e249. [CrossRef] [PubMed]

218. Li, L.; Peng, X.; Qin, Y.; Wang, R.; Tang, J.; Cui, X.; Wang, T.; Liu, W.; Pan, H.; Li, B. Acceleration of bone regeneration by activating wnt/ $\beta$-catenin signalling pathway via lithium released from lithium chloride/ calcium phosphate cement in osteoporosis. Sci. Rep. 2017, 7, 45204. [CrossRef] [PubMed]

219. Satija, N.K.; Sharma, D.; Afrin, F.; Tripathi, R.P.; Gangenahalli, G. High throughput transcriptome profiling of lithium stimulated human mesenchymal stem cells reveals priming towards osteoblastic lineage. PLoS ONE 2013, 8, e55769. [CrossRef] [PubMed]

220. Vachhani, K.; Whyne, C.; Wang, Y.; Burns, D.M.; Nam, D. Low-dose lithium regimen enhances endochondral fracture healing in osteoporotic rodent bone. J. Orthop. Res. 2018, 36, 1783-1789. [CrossRef] [PubMed]

221. Wang, Y.; Yang, X.; Gu, Z.; Qin, H.; Li, L.; Liu, J.; Yu, X. In vitro study on the degradation of lithium-doped hydroxyapatite for bone tissue engineering scaffold. Mater. Sci. Eng. C Mater. Biol. Appl. 2016, 66, 185-192. [CrossRef] [PubMed]

222. Li, D.; Huifang, L.; Zhao, J.; Yang, Z.; Xie, X.; Wei, Z.; Li, D.; Kang, P. Porous lithium-doped hydroxyapatite scaffold seeded with hypoxia-preconditioned bone-marrow mesenchymal stem cells for bone-tissue regeneration. Biomed. Mater. 2018, 13, 055002. [CrossRef] [PubMed]

223. Shainberg, A.P.M.; Valério, P.; Zonari, A.; Oktar, F.N.; Ozyegin, L.S.; Graça, M.P.F.; Leite, M.F.; Goes, A.M. Attachment and proliferation of osteoblasts on lithium-hydroxyapatite composites. Adv. Mater. Sci. Eng. 2012, 2012, 650574. [CrossRef]

224. Luo, Y.; Li, D.; Zhao, J.; Yang, Z.; Kang, P. In vivo evaluation of porous lithium-doped hydroxyapatite scaffolds for the treatment of bone defect. Bio-Med. Mater. Eng. 2018, in press. [CrossRef] [PubMed]

225. Ginty, F.; Flynn, A.; Cashman, K.D. The effect of dietary sodium intake on biochemical markers of bone metabolism in young women. Br. J. Nutr. 1998, 79, 343-350. [CrossRef] [PubMed]

226. Pohl, H.R.; Wheeler, J.S.; Murray, H.E. Sodium and potassium in health and disease. In Interrelations Between Essential Metal Ions and Human Diseases; Sigel, A., Sigel, H., Sigel, R.K.O., Eds.; Springer: Berlin, Germany, 2013; pp. 29-47. ISBN 978-94-007-7500-8.

227. Sang Cho, J.; Um, S.H.; Su Yoo, D.; Chung, Y.C.; Hye Chung, S.; Lee, J.C.; Rhee, S.H. Enhanced osteoconductivity of sodium-substituted hydroxyapatite by system instability. J. Biomed. Mater. Res. Part B 2014, 102, 1046-1062. [CrossRef] [PubMed]

228. Sigel, A.; Sigel, H.; Sigel, R.K. Interrelations between Essential Metal Ions and Human Diseases; Springer: Berlin, Germany, 2013; ISBN 978-94-007-7500-8.

229. Li, H.; Zhao, X.; Cao, S.; Li, K.; Chen, M.; Xu, Z.; Lu, J.; Zhang, L. Na-doped hydroxyapatite coating on carbon/carbon composites: Preparation, in vitro bioactivity and biocompatibility. Appl. Surf. Sci. 2012, 263, 163-173. [CrossRef]

230. Wiesmann, H.-P.; Plate, U.; Zierold, K.; Höhling, H. Potassium is involved in apatite biomineralization. J. Dent. Res. 1998, 77, 1654-1657. [CrossRef] [PubMed]

231. Kannan, S.; Ventura, J.M.G.; Ferreira, J.M.F. Synthesis and thermal stability of potassium substituted hydroxyapatites and hydroxyapatite/ $\beta$-tricalciumphosphate mixtures. Ceram. Int. 2007, 33, 1489-1494. [CrossRef]

232. Weissmueller, N.T.; Schiffter, H.A.; Carlisle, R.C.; Rollier, C.S.; Pollard, A.J. Needle-free dermal delivery of a diphtheria toxin CRM197 Mutant on potassium-doped hydroxyapatite microparticles. Clin. Vaccine Immunol. 2015, 22, 586-592. [CrossRef] [PubMed]

233. Weissmueller, N.T.; Schiffter, H.A.; Pollard, A.J.; Cuneyt Tas, A. Molten salt synthesis of potassium-containing hydroxyapatite microparticles used as protein substrate. Mater. Lett. 2014, 128, 421-424. [CrossRef] 
234. Stipniece, L.; Salma-Ancane, K.; Borodajenko, N.; Sokolova, M.; Jakovlevs, D.; Berzina-Cimdina, L. Characterization of Mg-substituted hydroxyapatite synthesized by wet chemical method. Ceram. Int. 2014, 40, 3261-3267. [CrossRef]

235. Landi, E.; Logroscino, G.; Proietti, L.; Tampieri, A.; Sandri, M.; Sprio, S. Biomimetic Mg-substituted hydroxyapatite: From synthesis to in vivo behaviour. J. Mater. Sci. Mater. Med. 2008, 19, 239-247. [CrossRef] [PubMed]

236. Andres, N.C.; D’Elia, N.L.; Ruso, J.M.; Campelo, A.E.; Massheimer, V.L.; Messina, P.V. Manipulation of $\mathrm{Mg}(2+)-\mathrm{Ca}(2+)$ switch on the development of bone mimetic hydroxyapatite. ACS Appl. Mater. Interfaces 2017, 9, 15698-15710. [CrossRef] [PubMed]

237. Andres, N.C.; Sieben, J.M.; Baldini, M.; Rodriguez, C.H.; Famiglietti, A.; Messina, P.V. Electroactive $\mathrm{Mg}(2+)$-hydroxyapatite nanostructured networks against drug-resistant bone infection strains. ACS Appl. Mater. Interfaces 2018, 10, 19534-19544. [CrossRef] [PubMed]

238. de Lima, I.R.; Alves, G.G.; Soriano, C.A.; Campaneli, A.P.; Gasparoto, T.H.; Ramos, E.S., Jr.; de Sena, L.A.; Rossi, A.M.; Granjeiro, J.M. Understanding the impact of divalent cation substitution on hydroxyapatite: An in vitro multiparametric study on biocompatibility. J. Biomed. Mater. Res. Part A 2011, 98, 351-358. [CrossRef] [PubMed]

239. Qi, G.; Zhang, S.; Khor, K.A.; Lye, S.W.; Zeng, X.; Weng, W.; Liu, C.; Venkatraman, S.S.; Ma, L.L. Osteoblastic cell response on magnesium-incorporated apatite coatings. Appl. Surf. Sci. 2008, 255, 304-307. [CrossRef]

240. Ran, J.; Jiang, P.; Sun, G.; Ma, Z.; Hu, J.; Shen, X.; Tong, H. Comparisons among Mg, Zn, Sr, and Si doped nano-hydroxyapatite/chitosan composites for load-bearing bone tissue engineering applications. Mater. Chem. Front. 2017, 1, 900-910. [CrossRef]

241. Prakasam, M.; Locs, J.; Salma-Ancane, K.; Loca, D.; Largeteau, A.; Berzina-Cimdina, L. Biodegradable materials and metallic implants-A review. J. Funct. Biomater. 2017, 8, 44. [CrossRef] [PubMed]

242. Sutha, S.; Dhineshbabu, N.; Prabhu, M.; Rajendran, V. Mg-doped hydroxyapatite/chitosan composite coated 3161 stainless steel implants for biomedical applications. J. Nanosci. Nanotechnol. 2015, 15, 4178-4187. [CrossRef] [PubMed]

243. Cox, S.C.; Jamshidi, P.; Grover, L.M.; Mallick, K.K. Preparation and characterisation of nanophase Sr, Mg, and Zn substituted hydroxyapatite by aqueous precipitation. Mater. Sci. Eng. C Mater. Biol. Appl. 2014, 35, 106-114. [CrossRef] [PubMed]

244. Aina, V.; Bergandi, L.; Lusvardi, G.; Malavasi, G.; Imrie, F.E.; Gibson, I.R.; Cerrato, G.; Ghigo, D. Sr-containing hydroxyapatite: Morphologies of HA crystals and bioactivity on osteoblast cells. Mater. Sci. Eng. C Mater. Biol. Appl. 2013, 33, 1132-1142. [CrossRef] [PubMed]

245. Capuccini, C.; Torricelli, P.; Sima, F.; Boanini, E.; Ristoscu, C.; Bracci, B.; Socol, G.; Fini, M.; Mihailescu, I.N.; Bigi, A. Strontium-substituted hydroxyapatite coatings synthesized by pulsed-laser deposition: In vitro osteoblast and osteoclast response. Acta Biomater. 2008, 4, 1885-1893. [CrossRef] [PubMed]

246. Xue, W.; Hosick, H.L.; Bandyopadhyay, A.; Bose, S.; Ding, C.; Luk, K.D.K.; Cheung, K.M.C.; Lu, W.W. Preparation and cell-materials interactions of plasma sprayed strontium-containing hydroxyapatite coating. Surf. Coat. Technol. 2007, 201, 4685-4693. [CrossRef]

247. Caverzasio, J. Strontium ranelate promotes osteoblastic cell replication through at least two different mechanisms. Bone 2008, 42, 1131-1136. [CrossRef] [PubMed]

248. Guo, X.; Wei, S.; Lu, M.; Shao, Z.; Lu, J.; Xia, L.; Lin, K.; Zou, D. Dose-dependent effects of strontium ranelate on ovariectomy rat bone marrow mesenchymal stem cells and human umbilical vein endothelial cells. Int. J. Biol. Sci. 2016, 12, 1511-1522. [CrossRef] [PubMed]

249. Yang, F.; Yang, D.; Tu, J.; Zheng, Q.; Cai, L.; Wang, L. Strontium enhances osteogenic differentiation of mesenchymal stem cells and in vivo bone formation by activating Wnt/catenin signaling. Stem Cells 2011, 29, 981-991. [CrossRef] [PubMed]

250. Fielding, G.A.; Roy, M.; Bandyopadhyay, A.; Bose, S. Antibacterial and biological characteristics of silver containing and strontium doped plasma sprayed hydroxyapatite coatings. Acta Biomater. 2012, 8, 3144-3152. [CrossRef] [PubMed]

251. Suganthi, R.; Elayaraja, K.; Joshy, M.A.; Chandra, V.S.; Girija, E.; Kalkura, S.N. Fibrous growth of strontium substituted hydroxyapatite and its drug release. Mater. Sci. Eng. C Mater. Biol. Appl. 2011, 31, 593-599. [CrossRef] 
252. Yu, N.; Cai, S.; Wang, F.; Zhang, F.; Ling, R.; Li, Y.; Jiang, Y.; Xu, G. Microwave assisted deposition of strontium doped hydroxyapatite coating on AZ31 magnesium alloy with enhanced mineralization ability and corrosion resistance. Ceram. Int. 2017, 43, 2495-2503. [CrossRef]

253. Montesi, M.; Panseri, S.; Dapporto, M.; Tampieri, A.; Sprio, S. Sr-substituted bone cements direct mesenchymal stem cells, osteoblasts and osteoclasts fate. PLoS ONE 2017, 12, e0172100. [CrossRef] [PubMed]

254. Landi, E.; Tampieri, A.; Celotti, G.; Sprio, S.; Sandri, M.; Logroscino, G. Sr-substituted hydroxyapatites for osteoporotic bone replacement. Acta Biomater. 2007, 3, 961-969. [CrossRef] [PubMed]

255. Ni, G.X.; Chiu, K.Y.; Lu, W.W.; Wang, Y.; Zhang, Y.G.; Hao, L.B.; Li, Z.Y.; Lam, W.M.; Lu, S.B.; Luk, K.D. Strontium-containing hydroxyapatite bioactive bone cement in revision hip arthroplasty. Biomaterials 2006, 27, 4348-4355. [CrossRef] [PubMed]

256. Shepherd, J.H.; Shepherd, D.V.; Best, S.M. Substituted hydroxyapatites for bone repair. J. Mater. Sci. Mater. Med. 2012, 23, 2335-2347. [CrossRef] [PubMed]

257. Ge, M.; Ge, K.; Gao, F.; Yan, W.; Liu, H.; Xue, L.; Jin, Y.; Ma, H.; Zhang, J. Biomimetic mineralized strontiumdoped hydroxyapatite on porous poly (l-lactic acid) scaffolds for bone defect repair. Int. J. Nanomed. 2018, 13, 1707-1721. [CrossRef] [PubMed]

258. Al-Haddad, A.; Che Ab Aziz, Z.A. Bioceramic-based root canal sealers: A review. Int. J. Biomater. 2016, 2016, 9753210. [CrossRef] [PubMed]

259. Kikuchi, M.; Yamazaki, A.; Akao, M.; Aoki, H. Cytotoxicity of synthetic barium hydroxyapatite. Bio-Med. Mater. Eng. 1996, 6, 405-413.

260. Shibata, S.; Doi, Y.; Takezawa, Y.; Wakamatsu, N.; Horiguchi, T.; Kamemizu, H.; Moriwaki, Y.; Kubo, F.; Haeuchi, Y. Self-setting apatite cement. VII. Barium-apatite as radio-opaque medium. Shika Zairyo Kikai/J. Jpn. Soc. Dent. Mater. Devices 1989, 8, 77-82.

261. Kaygili, O.; Keser, S.; Dorozhkin, S.V.; Yakuphanoglu, F.; Al-Ghamdi, A.A.; Kirbag, S.; Sertkaya, D.; Ates, T.; Gursoy, N.C. Structural and dielectrical properties of Ag- and Ba-substituted hydroxyapatites. J. Inorg. Organomet. Polym. Mater. 2014, 24, 1001-1008. [CrossRef]

262. Alshemary, A.Z.; Akram, M.; Goh, Y.-F.; Butt, F.K.; Hussian, R. In vitro bioactivity of barium doped biphasic calcium phosphate. J. Appl. Sci. Agric. 2014, 9, 102-106.

263. Kolekar, T.V.; Thorat, N.D.; Yadav, H.M.; Magalad, V.T.; Shinde, M.A.; Bandgar, S.S.; Kim, J.H.; Agawane, G.L. Nanocrystalline hydroxyapatite doped with aluminium: A potential carrier for biomedical applications. Ceram. Int. 2016, 42, 5304-5311. [CrossRef]

264. Mellier, C.; Fayon, F.; Boukhechba, F.; Verron, E.; LeFerrec, M.; Montavon, G.; Lesoeur, J.; Schnitzler, V.; Massiot, D.; Janvier, P.; et al. Design and properties of novel gallium-doped injectable apatitic cements. Acta Biomater. 2015, 24, 322-332. [CrossRef] [PubMed]

265. Melnikov, P.; Teixeira, A.R.; Malzac, A.; Coelho, M.D.B. Gallium-containing hydroxyapatite for potential use in orthopedics. Mater. Chem. Phys. 2009, 117, 86-90. [CrossRef]

266. Kurtjak, M.; Vukomanović, M.; Suvorov, D. Antibacterial nanocomposite of functionalized nanogold and gallium-doped hydroxyapatite. Mater. Lett. 2017, 193, 126-129. [CrossRef]

267. Webster, T.J.; Massa-Schlueter, E.A.; Smith, J.L.; Slamovich, E.B. Osteoblast response to hydroxyapatite doped with divalent and trivalent cations. Biomaterials 2004, 25, 2111-2121. [CrossRef] [PubMed]

268. Selvakumar, M.; Srivastava, P.; Pawar, H.S.; Francis, N.K.; Das, B.; Sathishkumar, G.; Subramanian, B.; Jaganathan, S.K.; George, G.; Anandhan, S. On-demand guided bone regeneration with microbial protection of ornamented SPU scaffold with bismuth-doped single crystalline hydroxyapatite: Augmentation and cartilage formation. ACS Appl. Mater. Interfaces 2016, 8, 4086-4100. [CrossRef] [PubMed]

269. Ciobanu, G.; Bargan, A.M.; Luca, C. New bismuth-substituted hydroxyapatite nanoparticles for bone tissue engineering. JOM 2015, 67, 2534-2542. [CrossRef]

270. Zare, B.; Faramarzi, M.A.; Sepehrizadeh, Z.; Shakibaie, M.; Rezaie, S.; Shahverdi, A.R. Biosynthesis and recovery of rod-shaped tellurium nanoparticles and their bactericidal activities. Mater. Res. Bull. 2012, 47, 3719-3725. [CrossRef]

271. Zhong, C.L.; Qin, B.Y.; Xie, X.Y.; Bai, Y. Antioxidant and antimicrobial activity of tellurium dioxide nanoparticles sols. J. Nano Res. 2013, 25, 8-15. [CrossRef]

272. Yahia, I.S.; Shkir, M.; AlFaify, S.; Ganesh, V.; Zahran, H.Y.; Kilany, M. Facile microwave-assisted synthesis of Te-doped hydroxyapatite nanorods and nanosheets and their characterizations for bone cement applications. Mater. Sci. Eng. C Mater. Biol. Appl. 2017, 72, 472-480. [CrossRef] [PubMed] 
273. Chen, W.; Liu, Y.; Courtney, H.S.; Bettenga, M.; Agrawal, C.M.; Bumgardner, J.D.; Ong, J.L. In vitro anti-bacterial and biological properties of magnetron co-sputtered silver-containing hydroxyapatite coating. Biomaterials 2006, 27, 5512-5517. [CrossRef] [PubMed]

274. Chung, R.-J.; Hsieh, M.-F.; Huang, K.-C.; Perng, L.-H.; Chou, F.-I.; Chin, T.-S. Anti-microbial hydroxyapatite particles synthesized by a sol-gel route. J. Sol-Gel Sci. Technol. 2005, 33, 229-239. [CrossRef]

275. Ciobanu, C.S.; Iconaru, S.L.; Chifiriuc, M.C.; Costescu, A.; Le Coustumer, P.; Predoi, D. Synthesis and antimicrobial activity of silver-doped hydroxyapatite nanoparticles. BioMed Res. Int. 2013, 2013, 916218. [CrossRef] [PubMed]

276. Ciobanu, C.S.; Iconaru, S.L.; Le Coustumer, P.; Constantin, L.V.; Predoi, D. Antibacterial activity of silverdoped hydroxyapatite nanoparticles against gram-positive and gram-negative bacteria. Nanoscale Res. Lett. 2012, 7, 324. [CrossRef] [PubMed]

277. Groza, A.; Ciobanu, C.; Popa, C.; Iconaru, S.; Chapon, P.; Luculescu, C.; Ganciu, M.; Predoi, D. Structural properties and antifungal activity against candida albicans biofilm of different composite layers based on $\mathrm{Ag} / \mathrm{Zn}$ doped hydroxyapatite-polydimethylsiloxanes. Polymers 2016, 8, 131. [CrossRef]

278. Kim, Y.S.; Min, B.G. Preparation of bio-polyurethane using castor oil and antibacterial hybrid films thereof with silver-doped hydroxyapatite. Fibers Polym. 2017, 18, 1841-1847. [CrossRef]

279. Mirzaee, M.; Vaezi, M.; Palizdar, Y. Synthesis and characterization of silver doped hydroxyapatite nanocomposite coatings and evaluation of their antibacterial and corrosion resistance properties in simulated body fluid. Mater. Sci. Eng. C Mater. Biol. Appl. 2016, 69, 675-684. [CrossRef] [PubMed]

280. Rameshbabu, N.; Sampath Kumar, T.S.; Prabhakar, T.G.; Sastry, V.S.; Murty, K.V.; Prasad Rao, K. Antibacterial nanosized silver substituted hydroxyapatite: Synthesis and characterization. J. Biomed. Mater. Res. Part A 2007, 80, 581-591. [CrossRef] [PubMed]

281. Samani, S.; Hossainalipour, S.M.; Tamizifar, M.; Rezaie, H.R. In vitro antibacterial evaluation of sol-gel-derived $\mathrm{Zn-}, \mathrm{Ag}-$, and $(\mathrm{Zn}+\mathrm{Ag})$-doped hydroxyapatite coatings against methicillin-resistant Staphylococcus aureus. J. Biomed. Mater. Res. Part A 2013, 101, 222-230. [CrossRef] [PubMed]

282. Singh, B.; Dubey, A.K.; Kumar, S.; Saha, N.; Basu, B.; Gupta, R. In vitro biocompatibility and antimicrobial activity of wet chemically prepared $\mathrm{Ca}_{10-\mathrm{x}} \mathrm{Ag}_{\mathrm{x}}\left(\mathrm{PO}_{4}\right)_{6}(\mathrm{OH})_{2}(0.0 \leq \mathrm{x} \leq 0.5)$ hydroxyapatites. Mater. Sci. Eng. C Mater. Biol. Appl. 2011, 31, 1320-1329. [CrossRef]

283. Ueno, M.; Miyamoto, H.; Tsukamoto, M.; Eto, S.; Noda, I.; Shobuike, T.; Kobatake, T.; Sonohata, M.; Mawatari, M. Silver-containing hydroxyapatite coating reduces biofilm formation by Methicillin-Resistant Staphylococcus aureus in vitro and in vivo. BioMed Res. Int. 2016, 2016, 8070597. [CrossRef] [PubMed]

284. Dubnika, A.; Loca, D.; Rudovica, V.; Parekh, M.B.; Berzina-Cimdina, L. Functionalized silver doped hydroxyapatite scaffolds for controlled simultaneous silver ion and drug delivery. Ceram. Int. 2017, 43, 3698-3705. [CrossRef]

285. Zhuk, I.; Rasskazova, L.; Korotchenko, N.; Kozik, V.; Kurzina, I. Synthesis and investigation of physico-chemical, antibacterial, biomymetic properties of silver and zinc containing hydroxyapatite. AIP Conf. Proc. 2017, 1899, 020017. [CrossRef]

286. Fonseca, F.; Costa, A.; Campos, J.; Marçal, R.; Rocha, D. Bioactivity assessment of Ag-HA. Biomater. Med. Appl. 2017, 1, 1000106. [CrossRef]

287. Begam, H.; Kundu, B.; Chanda, A.; Nandi, S.K. MG63 osteoblast cell response on Zn doped hydroxyapatite (HAp) with various surface features. Ceram. Int. 2017, 43, 3752-3760. [CrossRef]

288. Hidalgo-Robatto, B.M.; López-Álvarez, M.; Azevedo, A.S.; Dorado, J.; Serra, J.; Azevedo, N.F.; González, P. Pulsed laser deposition of copper and zinc doped hydroxyapatite coatings for biomedical applications. Surf. Coat. Technol. 2018, 333, 168-177. [CrossRef]

289. Li, Y.; Shi, X.; Li, W. Zinc-containing hydroxyapatite enhances cold-light-activated tooth bleaching treatment in vitro. BioMed Res. Int. 2017, 2017, 6261248. [CrossRef] [PubMed]

290. Fu, X.; Li, Y.; Huang, T.; Yu, Z.; Ma, K.; Yang, M.; Liu, Q.; Pan, H.; Wang, H.; Wang, J. Runx2/osterix and zinc uptake synergize to orchestrate osteogenic differentiation and citrate containing bone apatite formation. Adv. Sci. 2018, 5, 1700755. [CrossRef] [PubMed]

291. Popa, C.L.; Deniaud, A.; Michaud-Soret, I.; Guégan, R.; Motelica-Heino, M.; Predoi, D. Structural and biological assessment of zinc doped hydroxyapatite nanoparticles. J. Nanomater. 2016, 2016, 1062878. [CrossRef] 
292. Zhong, Z.; Ma, J. Fabrication, characterization, and in vitro study of zinc substituted hydroxyapatite/silk fibroin composite coatings on titanium for biomedical applications. J. Biomater. Appl. 2017, 32, 399-409. [CrossRef] [PubMed]

293. Anwar, A.; Akbar, S.; Sadiqa, A.; Kazmi, M. Novel continuous flow synthesis, characterization and antibacterial studies of nanoscale zinc substituted hydroxyapatite bioceramics. Inorg. Chim. Acta 2016, 453, 16-22. [CrossRef]

294. Ohtsu, N.; Kakuchi, Y.; Ohtsuki, T. Antibacterial effect of zinc oxide/hydroxyapatite coatings prepared by chemical solution deposition. Appl. Surf. Sci. 2018, 445, 596-600. [CrossRef]

295. Sathiskumar, S.; Vanaraj, S.; Sabarinathan, D.; Preethi, K. Evaluation of antibacterial and antibiofilm activity of synthesized zinc-hydroxyapatite biocomposites from Labeo rohita fish scale waste. Mater. Res. Express 2018, 5, 025407. [CrossRef]

296. Iconaru, S.L.; Prodan, A.M.; Buton, N.; Predoi, D. Structural characterization and antifungal studies of zinc-doped hydroxyapatite coatings. Molecules 2017, 22, 604. [CrossRef] [PubMed]

297. Yang, H.; Qu, X.; Lin, W.; Wang, C.; Zhu, D.; Dai, K.; Zheng, Y. In vitro and in vivo studies on zinc-hydroxyapatite composites as novel biodegradable metal matrix composite for orthopedic applications. Acta Biomater. 2018, 71, 200-214. [CrossRef] [PubMed]

298. Begam, H.; Nandi, S.K.; Chanda, A.; Kundu, B. Effect of bone morphogenetic protein on zn-hap and zn-hap/collagen composite: A systematic in vivo study. Res. Vet. Sci. 2017, 115, 1-9. [CrossRef] [PubMed]

299. Shanmugam, S.; Gopal, B. Copper substituted hydroxyapatite and fluorapatite: Synthesis, characterization and antimicrobial properties. Ceram. Int. 2014, 40, 15655-15662. [CrossRef]

300. Stanić, V.; Dimitrijević, S.; Antić-Stanković, J.; Mitrić, M.; Jokić, B.; Plećaš, I.B.; Raičević, S. Synthesis, characterization and antimicrobial activity of copper and zinc-doped hydroxyapatite nanopowders. Appl. Surf. Sci. 2010, 256, 6083-6089. [CrossRef]

301. Li, Y.; Ho, J.; Ooi, C.P. Antibacterial efficacy and cytotoxicity studies of copper (II) and titanium (IV) substituted hydroxyapatite nanoparticles. Mater. Sci. Eng. C Mater. Biol. Appl. 2010, 30, 1137-1144. [CrossRef]

302. Huang, Y.; Zhang, X.; Zhao, R.; Mao, H.; Yan, Y.; Pang, X. Antibacterial efficacy, corrosion resistance, and cytotoxicity studies of copper-substituted carbonated hydroxyapatite coating on titanium substrate. J. Mater. Sci. 2015, 50, 1688-1700. [CrossRef]

303. Shi, F.; Liu, Y.; Zhi, W.; Xiao, D.; Li, H.; Duan, K.; Qu, S.; Weng, J. The synergistic effect of micro/nano-structured and $\mathrm{Cu}(2+)$-doped hydroxyapatite particles to promote osteoblast viability and antibacterial activity. Biomed. Mater. 2017, 12, 035006. [CrossRef] [PubMed]

304. Ananth, K.; Sun, J.; Bai, J. An innovative approach to manganese-substituted hydroxyapatite coating on zinc oxide-coated 316L SS for implant application. Int. J. Mol. Sci. 2018, 19, 2340. [CrossRef] [PubMed]

305. Huang, Y.; Ding, Q.; Han, S.; Yan, Y.; Pang, X. Characterisation, corrosion resistance and in vitro bioactivity of manganese-doped hydroxyapatite films electrodeposited on titanium. J. Mater. Sci. Mater. Med. 2013, 24, 1853-1864. [CrossRef] [PubMed]

306. Kang, J.-I.; Son, M.-K.; Choe, H.-C.; Brantley, W.A. Bone-like apatite formation on manganese-hydroxyapatite coating formed on Ti-6Al-4V alloy by plasma electrolytic oxidation. Thin Solid Films 2016, 620, 126-131. [CrossRef]

307. Kandori, K.; Murata, R.; Yamaguchi, Y.; Yoshioka, A. Protein adsorption behaviors onto Mn(II)-doped calcium hydroxyapatite particles with different morphologies. Colloid Surf. B Biointerfaces 2018, 167, $36-43$. [CrossRef] [PubMed]

308. Li, Y.; Widodo, J.; Lim, S.; Ooi, C.P. Synthesis and cytocompatibility of manganese (II) and iron (III) substituted hydroxyapatite nanoparticles. J. Mater. Sci. 2012, 47, 754-763. [CrossRef]

309. Zilm, M.E.; Yu, L.; Hines, W.A.; Wei, M. Magnetic properties and cytocompatibility of transition-metalincorporated hydroxyapatite. Mater. Sci. Eng. C Mater. Biol. Appl. 2018, 87, 112-119. [CrossRef] [PubMed]

310. Sarath Chandra, V.; Baskar, G.; Suganthi, R.; Elayaraja, K.; Ahymah Joshy, M.; Sofi Beaula, W.; Mythili, R.; Venkatraman, G.; Narayana Kalkura, S. Blood compatibility of iron-doped nanosize hydroxyapatite and its drug release. ACS Appl. Mater. Interfaces 2012, 4, 1200-1210. [CrossRef] [PubMed]

311. Ulum, M.; Arafat, A.; Noviana, D.; Yusop, A.; Nasution, A.; Kadir, M.A.; Hermawan, H. In vitro and in vivo degradation evaluation of novel iron-bioceramic composites for bone implant applications. Mater. Sci. Eng. C Mater. Biol. Appl. 2014, 36, 336-344. [CrossRef] [PubMed] 
312. Sheikh, L.; Sinha, S.; Singhababu, Y.N.; Verma, V.; Tripathy, S.; Nayar, S. Traversing the profile of biomimetically nanoengineered iron substituted hydroxyapatite: Synthesis, characterization, property evaluation, and drug release modeling. RSC Adv. 2018, 8, 19389-19401. [CrossRef]

313. Hou, C.H.; Hou, S.M.; Hsueh, Y.S.; Lin, J.; Wu, H.C.; Lin, F.H. The in vivo performance of biomagnetic hydroxyapatite nanoparticles in cancer hyperthermia therapy. Biomaterials 2009, 30, 3956-3960. [CrossRef] [PubMed]

314. Yang, C.T.; Li, K.Y.; Meng, F.Q.; Lin, J.F.; Young, I.C.; Ivkov, R.; Lin, F.H. ROS-induced HepG2 cell death from hyperthermia using magnetic hydroxyapatite nanoparticles. Nanotechnology 2018, 29, 375101. [CrossRef] [PubMed]

315. Sidambe, A.T. Biocompatibility of advanced manufactured titanium implants-A review. Materials 2014, 7, 8168-8188. [CrossRef] [PubMed]

316. Nakazawa, M.; Yamada, M.; Wakamura, M.; Egusa, H.; Sakurai, K. Activation of osteoblastic function on titanium surface with titanium-doped hydroxyapatite nanoparticle coating: An in vitro study. Int. J. Oral Maxillofac. Implants 2017, 32, 779-791. [CrossRef] [PubMed]

317. Siek, D.; Czechowska, J.; Mróz, W.; Zima, A.; Burdyńska, S.; Załęczny, R.; Ślósarczyk, A. Bioactivity of cement type bone substitutes. Bull. Pol. Acad. Sci.-Tech. Sci. 2013, 61, 433-439. [CrossRef]

318. Surmeneva, M.A.; Vladescu, A.; Surmenev, R.A.; Pantilimon, C.M.; Braic, M.; Cotrut, C.M. Study on a hydrophobic ti-doped hydroxyapatite coating for corrosion protection of a titanium based alloy. RSC Adv. 2016, 6, 87665-87674. [CrossRef]

319. Bandgar, S.S.; Yadav, H.M.; Shirguppikar, S.S.; Shinde, M.A.; Shejawal, R.V.; Kolekar, T.V.; Bamane, S.R. Enhanced hemolytic biocompatibility of hydroxyapatite by chromium $\left(\mathrm{Cr}^{3+}\right)$ doping in hydroxyapatite nanoparticles synthesized by solution combustion method. J. Korean Ceram. Soc. 2017, 54, 158-166. [CrossRef]

320. Pantaleão, S.D.M.; Santos, M.D.; Anjos, H.A.; Lima, A.D.; Valadares, B.L.B.; Nunes, R.; Feitosa, M.B.D.J. Evaluation of mutagenic effects of pure hydroxyapatite doped with chromium (III) through the SMART Test in Drosophila melanogaster Meigen, 1830 (Diptera: Drosophilidae). Braz. J. Biol. Sci. 2017, 4, 293-300. [CrossRef]

321. Tank, K.P.; Chudasama, K.S.; Thaker, V.S.; Joshi, M.J. Cobalt-doped nanohydroxyapatite: Synthesis, characterization, antimicrobial and hemolytic studies. J. Nanopart. Res. 2013, 15, 1644. [CrossRef]

322. Kulanthaivel, S.; Roy, B.; Agarwal, T.; Giri, S.; Pramanik, K.; Pal, K.; Ray, S.S.; Maiti, T.K.; Banerjee, I. Cobalt doped proangiogenic hydroxyapatite for bone tissue engineering application. Mater. Sci. Eng. C Mater. Biol. Appl. 2016, 58, 648-658. [CrossRef] [PubMed]

323. Ignjatović, N.; Ajduković, Z.; Rajković, J.; Najman, S.; Mihailović, D.; Uskoković, D. Enhanced osteogenesis of nanosized cobalt-substituted hydroxyapatite. J. Bionic Eng. 2015, 12, 604-612. [CrossRef]

324. Dhal, J.; Bose, S.; Bandyopadhyay, A. Influence of pentavalent dopant addition to polarization and bioactivity of hydroxyapatite. Mater. Sci. Eng. C Mater. Biol. Appl. 2013, 33, 3061-3068. [CrossRef] [PubMed]

325. Ligot, S.; Godfroid, T.; Music, D.; Bousser, E.; Schneider, J.M.; Snyders, R. Tantalum-doped hydroxyapatite thin films: Synthesis and characterization. Acta Mater. 2012, 60, 3435-3443. [CrossRef]

326. Civjan, S.; Huget, E.F.; DeSimon, L.B. Potential applications of certain nickel-titanium (nitinol) alloys. J. Dent. Res. 1975, 54, 89-96. [CrossRef] [PubMed]

327. Fini, M.; Aldini, N.N.; Torricelli, P.; Giavaresi, G.; Borsari, V.; Lenger, H.; Bernauer, J.; Giardino, R.; Chiesa, R.; Cigada, A. A new austenitic stainless steel with negligible nickel content: An in vitro and in vivo comparative investigation. Biomaterials 2003, 24, 4929-4939. [CrossRef]

328. Priya, B.A.; Senthilguru, K.; Agarwal, T.; Narayana, S.G.H.; Giri, S.; Pramanik, K.; Pal, K.; Banerjee, I. Nickel doped nanohydroxyapatite: Vascular endothelial growth factor inducing biomaterial for bone tissue engineering. RSC Adv. 2015, 5, 72515-72528. [CrossRef]

329. Alshemary, A.Z.; Akram, M.; Goh, Y.-F.; Tariq, U.; Butt, F.K.; Abdolahi, A.; Hussain, R. Synthesis, characterization, in vitro bioactivity and antimicrobial activity of magnesium and nickel doped silicate hydroxyapatite. Ceram. Int. 2015, 41, 11886-11898. [CrossRef]

330. Abutalib, M.M.; Yahia, I.S. Novel and facile microwave-assisted synthesis of Mo-doped hydroxyapatite nanorods: Characterization, gamma absorption coefficient, and bioactivity. Mater. Sci. Eng. C Mater. Biol. Appl. 2017, 78, 1093-1100. [CrossRef] [PubMed] 
331. Sato, M.; Sambito, M.A.; Aslani, A.; Kalkhoran, N.M.; Slamovich, E.B.; Webster, T.J. Increased osteoblast functions on undoped and yttrium-doped nanocrystalline hydroxyapatite coatings on titanium. Biomaterials 2006, 27, 2358-2369. [CrossRef] [PubMed]

332. Webster, T.J.; Ergun, C.; Doremus, R.H.; Bizios, R. Hydroxylapatite with substituted magnesium, zinc, cadmium, and yttrium. II. Mechanisms of osteoblast adhesion. J. Biomed. Mater. Res. 2002, 59, 312-317. [CrossRef] [PubMed]

333. Thomas, S.; Gabriel, M.C.; de Souza, S.A.; Gomes, S.C.; Assi, P.E.; Pinheiro Perri, M.L.; Liberato, W.; Matushita, C.S.; Gutfilen, B.; da Fonseca, L.M. 90 Yttrium-hydroxyapatite: A new therapeutic option for radioactive synovectomy in haemophilic synovitis. Haemophilia 2011, 17, e985-e989. [CrossRef] [PubMed]

334. Gao, M.; Yang, Y.; Lv, M.; Song, W.; Song, Z. Oxidative stress and DNA damage in zebrafish liver due to hydroxyapatite nanoparticles-loaded cadmium. Chemosphere 2018, 202, 498-505. [CrossRef] [PubMed]

335. Huang, Y.; Qiu, W.; Yu, Z.; Song, Z. Toxic effect of cadmium adsorbed by different sizes of nanohydroxyapatite on the growth of rice seedlings. Environ. Toxicol. Pharmacol. 2017, 52, 1-7. [CrossRef] [PubMed]

336. Shkir, M.; Kilany, M.; Yahia, I.S. Facile microwave-assisted synthesis of tungsten-doped hydroxyapatite nanorods: A systematic structural, morphological, dielectric, radiation and microbial activity studies. Ceram. Int. 2017, 43, 14923-14931. [CrossRef]

337. Maggiorella, L.; Barouch, G.; Devaux, C.; Pottier, A.; Deutsch, E.; Bourhis, J.; Borghi, E.; Levy, L. Nanoscale radiotherapy with hafnium oxide nanoparticles. Future Oncol. 2012, 8, 1167-1181. [CrossRef] [PubMed]

338. Mendoza, J.G.; Frutis, M.A.; Flores, G.A.; Hipólito, M.G.; Cerda, A.M.; Nieto, J.A.; Montalvo, T.R.; Falcony, C. Synthesis and characterization of hafnium oxide films for thermo and photoluminescence applications. Appl. Radiat. Isot. 2010, 68, 696-699. [CrossRef] [PubMed]

339. Chen, M.H.; Hanagata, N.; Ikoma, T.; Huang, J.Y.; Li, K.Y.; Lin, C.P.; Lin, F.H. Hafnium-doped hydroxyapatite nanoparticles with ionizing radiation for lung cancer treatment. Acta Biomater. 2016, 37, 165-173. [CrossRef] [PubMed]

340. Lou, W.; Dong, Y.; Zhang, H.; Jin, Y.; Hu, X.; Ma, J.; Liu, J.; Wu, G. Preparation and characterization of lanthanum-incorporated hydroxyapatite coatings on titanium substrates. Int. J. Mol. Sci. 2015, 16, 21070-21086. [CrossRef] [PubMed]

341. Bulina, N.V.; Chaikina, M.V.; Prosanov, I.Y.; Dudina, D.V.; Solovyov, L.A. Fast synthesis of La-substituted apatite by the dry mechanochemical method and analysis of its structure. J. Solid State Chem. 2017, 252, 93-99. [CrossRef]

342. Guo, D.G.; Wang, A.H.; Han, Y.; Xu, K.W. Characterization, physicochemical properties and biocompatibility of La-incorporated apatites. Acta Biomater. 2009, 5, 3512-3523. [CrossRef] [PubMed]

343. Hendi, A.A. Hydroxyapatite based nanocomposite ceramics. J. Alloys Compd. 2017, 712, 147-151. [CrossRef]

344. Sundarabharathi, L.; Chinnaswamy, M.; Ponnamma, D.; Parangusan, H.; Al-Maadeed, M.A.A. Investigation of antimicrobial properties and in-vitro bioactivity of $\mathrm{Ce}^{3+}-\mathrm{Sr}^{2+}$ dual-substituted nano hydroxyapatites. J. Am. Ceram. Soc. 2018. [CrossRef]

345. Kaur, K.; Singh, K.J.; Anand, V.; Islam, N.; Bhatia, G.; Kalia, N.; Singh, J. Lanthanide (=Ce, Pr, Nd and Tb) ions substitution at calcium sites of hydroxyl apatite nanoparticles as fluorescent bio probes: Experimental and density functional theory study. Ceram. Int. 2017, 43, 10097-10108. [CrossRef]

346. Huang, Y.; Wang, Y.; Ning, C.; Nan, K.; Han, Y. Preparation and properties of a cerium-containing hydroxyapatite coating on commercially pure titanium by micro-arc oxidation. Rare Met. 2008, 27, 257-260. [CrossRef]

347. Khusayfan, N.M. Ferroelectric properties of Ce doped hydroxyapatite nanoceramics. J. Alloys Compd. 2016, 685, 350-354. [CrossRef]

348. Priyadarshini, B.; Anjaneyulu, U.; Vijayalakshmi, U. Preparation and characterization of sol-gel derived Ce $\mathrm{e}^{4+}$ doped hydroxyapatite and its in vitro biological evaluations for orthopedic applications. Mater. Des. 2017, 119, 446-455. [CrossRef]

349. Yuan, Q.; Qin, C.; Wu, J.; Xu, A.; Zhang, Z.; Liao, J.; Lin, S.; Ren, X.; Zhang, P. Synthesis and characterization of cerium-doped hydroxyapatite/polylactic acid composite coatings on metal substrates. Mater. Chem. Phys. 2016, 182, 365-371. [CrossRef] 
350. Setiawan, D.; Nurhasan, D. Sintesis dan karakterisasi praseodymium-142 hidroksiapatit (142pr-ha). In Proceedings of the Penelitian Dasar Ilmu Pengetahuan dan Teknologi Nuklir 2015 Pusat Sains dan Teknologi Akselerator, Yogyakarta, Indonesia, 9-10 June 2015; pp. 27-32.

351. Starostenko, N.V.; Get'man, E.I.; Loboda, S.N.; Pasechnik, L.V.; Marchenko, V.I. Substitutions of praseodymium and silicon for calcium and phosphorus in hydroxyapatite structure. Russ. J. Inorg. Chem. 2012, 57, 1192-1195. [CrossRef]

352. Victor, S.P.; Paul, W.; Vineeth, V.M.; Komeri, R.; Jayabalan, M.; Sharma, C.P. Neodymium doped hydroxyapatite theranostic nanoplatforms for colon specific drug delivery applications. Colloid Surf. B Biointerfaces 2016, 145, 539-547. [CrossRef] [PubMed]

353. Hosseini, S.M.; Drouet, C.; Al-Kattan, A.; Navrotsky, A. Energetics of lanthanide-doped calcium phosphate apatite. Am. Miner. 2014, 99, 2320-2327. [CrossRef]

354. Sathishkumar, S.; Louis, K.; Shinyjoy, E.; Gopi, D. Tailoring the Sm/Gd-substituted hydroxyapatite coating on biomedical AISI 316L SS: Exploration of corrosion resistance, protein profiling, osteocompatibility, and osteogenic differentiation for orthopedic implant applications. Ind. Eng. Chem. Res. 2016, 55, 6331-6344. [CrossRef]

355. Ciobanu, C.S.; Iconaru, S.L.; Popa, C.L.; Motelica-Heino, M.; Predoi, D. Evaluation of samarium doped hydroxyapatite, ceramics for medical application: Antimicrobial activity. J. Nanomater. 2015, 2015, 849216. [CrossRef]

356. Gangu, K.K.; Maddila, S.; Maddila, S.N.; Jonnalagadda, S.B. Nanostructured samarium doped fluorapatites and their catalytic activity towards synthesis of 1,2,4-triazoles. Molecules 2016, 21, 1281. [CrossRef] [PubMed]

357. Iconaru, S.; Stanciu, G.; Hristu, R.; Ghita, R. Properties of samarium doped hydroxyapatite thin films deposited by evaporation. Rom. Rep. Phys. 2017, 69, 508.

358. Lv, Y.; Shi, Q.; Jin, Y.; Ren, H.; Qin, Y.; Wang, B.; Song, S. Preparation and luminescent properties of the antibacterial materials of the $\mathrm{La}^{3+}$ doped $\mathrm{Sm}^{3+}$-hydroxyapatite. J. Phys. Conf. Ser. 2018, 986, 012010. [CrossRef]

359. Morais, D.S.; Coelho, J.; Ferraz, M.P.; Gomes, P.S.; Fernandes, M.H.; Hussain, N.S.; Santos, J.D.; Lopes, M.A. Samarium doped glass-reinforced hydroxyapatite with enhanced osteoblastic performance and antibacterial properties for bone tissue regeneration. J. Mater. Chem. B 2014, 2, 5872-5881. [CrossRef]

360. Prichodko, A.; Enrichi, F.; Stankeviciute, Z.; Benedetti, A.; Grigoraviciute-Puroniene, I.; Kareiva, A. Study of Eu3+ and Tm3+ substitution effects in sol-gel fabricated calcium hydroxyapatite. J. Sol-Gel Sci. Technol. 2016, 81, 261-267. [CrossRef]

361. Mondéjar, S.P.; Kovtun, A.; Epple, M. Lanthanide-doped calcium phosphate nanoparticles with high internal crystallinity and with a shell of DNA as fluorescent probes in cell experiments. J. Mater. Chem. 2007, 17, 4153-4159. [CrossRef]

362. Andronescu, E.; Surugiu, A.; Badea, M.L.; Ciobanu, C.S.; Iosif, A. Antimicrobial activity of europium doped hydroxyapatite powders after immersion in SBF solution. Univ. Politeh. Buchar. Sci. Bull. Ser. B Chem. Mater. Sci. 2016, 78, 147-154.

363. Frumosu, F.; Iconaru, S.; Predoi, D. Europium concentration effect of europium doped hydroxyapatite on proliferation of osteoblast cells. Dig. J. Nanomater. Biostruct. 2011, 6, 1859-1865.

364. Miranda-Melendez, P.G.; Martinez-Castanon, G.A.; Nino-Martinez, N.; Patino-Marin, N.; Casillas-Santana, M.A.; Castillo-Silva, B.E.; Ruiz, F. Facile synthesis, characterization, and cytotoxic activity of europium-doped nanohydroxyapatite. Bioinorg. Chem. Appl. 2016, 2016, 1057260. [CrossRef] [PubMed]

365. Popa, C.L.; Ciobanu, C.S.; Iconaru, S.L.; Stan, M.; Dinischiotu, A.; Negrila, C.C.; Motelica-Heino, M.; Guegan, R.; Predoi, D. Systematic investigation and in vitro biocompatibility studies on mesoporous europium doped hydroxyapatite. Cent. Eur. J. Chem. 2014, 12, 1032-1046. [CrossRef]

366. Victor, S.P.; Gayathri Devi, M.G.; Paul, W.; Vijayan, V.M.; Muthu, J.; Sharma, C.P. Europium doped calcium deficient hydroxyapatite as theranostic nanoplatforms: Effect of structure and aspect ratio. ACS Biomater. Sci. Eng. 2017, 3, 3588-3595. [CrossRef]

367. Xu, L.; Zheng, T.; Yang, S.; Zhang, L.; Wang, J.; Liu, W.; Chen, L.; Diwu, J.; Chai, Z.; Wang, S. Uptake mechanisms of $\mathrm{Eu}(\mathrm{III})$ on hydroxyapatite: A potential permeable reactive barrier backfill material for trapping trivalent minor actinides. Environ. Sci. Technol. 2016, 50, 3852-3859. [CrossRef] [PubMed] 
368. Cipreste, M.F.; Peres, A.M.; Cotta, A.A.C.; Aragón, F.H.; Antunes, A.D.M.; Leal, A.S.; Macedo, W.A.A.; de Sousa, E.M.B. Synthesis and characterization of 159 Gd-doped hydroxyapatite nanorods for bioapplications as theranostic systems. Mater. Chem. Phys. 2016, 181, 301-311. [CrossRef]

369. Wang, X.; Zhang, Y.; Lin, C.; Zhong, W. Sol-gel derived terbium-containing mesoporous bioactive glasses nanospheres: In vitro hydroxyapatite formation and drug delivery. Colloid Surf. B Biointerfaces 2017, 160, 406-415. [CrossRef] [PubMed]

370. Zhao, Y.-Z.; Yang, M.; Zhang, H.-B.; Zhu, J.; Zhou, K.-C. Characterization of terbium-doped nanohydroxyapatite and surface modification. J. Cent. South Univ. 2016, 23, 1548-1555. [CrossRef]

371. Unni, P.; Chaudhari, P.; Venkatesh, M.; Ramamoorthy, N.; Pillai, M. Preparation and bioevaluation of $166 \mathrm{Ho}$ labelled hydroxyapatite (HA) particles for radiosynovectomy. Nucl. Med. Biol. 2002, 29, 199-209. [CrossRef]

372. Alshemary, A.Z.; Akram, M.; Goh, Y.-F.; Abdul Kadir, M.R.; Abdolahi, A.; Hussain, R. Structural characterization, optical properties and in vitro bioactivity of mesoporous erbium-doped hydroxyapatite. J. Alloys Compd. 2015, 645, 478-486. [CrossRef]

373. Zavala, L.A.; Fernández, P.; Novitskaya, E.; Díaz, J.N.; Herrera, M.; Graeve, O.A. Interconfigurational and intraconfigurational transitions of $\mathrm{Yb}^{2+}$ and $\mathrm{Yb}^{3+}$ ions in hydroxyapatite: A cathodoluminescence study. Acta Mater. 2017, 135, 35-43. [CrossRef]

374. Chatelain, G.; Bourgeois, D.; Ravaux, J.; Averseng, O.; Vidaud, C.; Meyer, D. Alternate dipping preparation of biomimetic apatite layers in the presence of carbonate ions. Biomed. Mater. 2014, 9, 015003. [CrossRef] [PubMed]

375. Chatelain, G.; Bourgeois, D.; Ravaux, J.; Averseng, O.; Vidaud, C.; Meyer, D. Incorporation of uranium into a biomimetic apatite: Physicochemical and biological aspects. J. Biol. Inorg. Chem. 2015, 20, 497-507. [CrossRef] [PubMed]

376. Cawthray, J.F.; Creagh, A.L.; Haynes, C.A.; Orvig, C. Ion exchange in hydroxyapatite with lanthanides. Inorg. Chem. 2015, 54, 1440-1445. [CrossRef] [PubMed]

377. Lin, Y.; Yang, Z.; Cheng, J. Preparation, Characterization and Antibacterial Property of Cerium Substituted Hydroxyapatite Nanoparticles. J. Rare Earths 2007, 25, 452-456. [CrossRef]

378. El-Meliegy, E.; Farag, M.M.; El-Kady, A.M.; Mohamed, M.S.; Abdelhakim, H.K.; Moaness, M. Evaluation of solubility and cytotoxicity of lanthanum-doped phosphate glasses nanoparticles for drug delivery applications. J. Non-Cryst. Solids 2017, 475, 59-70. [CrossRef]

379. Ahymah Joshy, M.I.; Elayaraja, K.; Suganthi, R.V.; Chandra Veerla, S.; Kalkura, S.N. In vitro sustained release of amoxicillin from lanthanum hydroxyapatite nano rods. Curr. Appl. Phys. 2011, 11, 1100-1106. [CrossRef]

380. Jadalannagari, S.; Deshmukh, K.; Verma, A.K.; Kowshik, R.V.; Meenal Ramanan, S.R. Lanthanum-doped hydroxyapatite nanoparticles as biocompatible fluorescent probes for cellular internalization and biolabeling. Sci. Adv. Mater. 2014, 6, 312-319. [CrossRef]

381. Baskaran, P.; Udduttula, A.; Uthirapathy, V. Development and characterisation of novel Ce-doped hydroxyapatite- $\mathrm{Fe}_{3} \mathrm{O}_{4}$ nanocomposites and their in vitro biological evaluations for biomedical applications. IET Nanobiotechnol. 2018, 12, 138-146. [CrossRef]

382. Ciobanu, C.; Popa, C.; Predoi, D. Cerium doped hydroxyapatite nanoparticles synthesized by coprecipitation method. J. Serb. Chem. Soc. 2016, 81, 433-446. [CrossRef]

383. Heshmatpour, F.; Lashteneshaee, S.H.; Samadipour, M. Study of in vitro bioactivity of nano hydroxyapatite composites doped by various cations. J. Inorg. Organomet. Polym. Mater. 2018, 28, 2063-2068. [CrossRef]

384. Rajeswari, D.; Gopi, D.; Ramya, S.; Kavitha, L. Investigation of anticorrosive, antibacterial and in vitro biological properties of a sulphonated poly (etheretherketone)/strontium, cerium co-substituted hydroxyapatite composite coating developed on surface treated surgical grade stainless steel for orthopedic applications. RSC Adv. 2014, 4, 61525-61536. [CrossRef]

385. Ciobanu, G.; Maria Bargan, A.; Luca, C. New cerium(IV)-substituted hydroxyapatite nanoparticles: Preparation and characterization. Ceram. Int. 2015, 41, 12192-12201. [CrossRef]

386. Huang, W.; Mao, Z.; Chen, L.; Chi, Y.; Jiang, H.; Zimba, B.L.; Xiong, G.; Wu, Q. Synthesis and characterisation of fluorescent and biocompatible hydroxyapatite nanoparticles with cerium doping. Micro Nano Lett. 2018, 13, 699-703. [CrossRef]

387. Sanyal, V.; Raja, C.R. Influence of sol-gel derived strontium-cerium co-substitution in fluorohydroxyapatite and its in-vitro bioactivity. J. Sol-Gel Sci. Technol. 2017, 83, 596-608. [CrossRef] 
388. Andronescu, E.; Iordache, F.; Ciobanu, C.; Badea, M.; Costescu, A.; Prodan, A. Optical properties of bioactive europium doped hydroxyapatite (HAp: $\mathrm{Eu}^{3+}$ ). Optoelectron. Adv. Mater. Rapid Commun. 2015, 9, 1155-1159.

389. Iconaru, S.-L.; Motelica-Heino, M.; Predoi, D. Study on europium-doped hydroxyapatite nanoparticles by fourier transform infrared spectroscopy and their antimicrobial properties. J. Spectrosc. 2013, 2013, 284285. [CrossRef]

390. Ciobanu, C.; Massuyeau, F.; Andronescu, E.; Stan, M.; Dinischiotu, A.; Predoi, D. Biocompatibility study of europium doped crystalline hydroxyapatite bioceramics. Dig. J. Nanomater. Biostruct. 2011, 6, 1639-1647.

391. Ma, X.; Liu, Y.; Wu, X.M.; Wang, C.; Li, Q.; Fu, T. Synthesis of europium-doped nanohydroxyapatite and its cytocompatibility with endothelial cells in vitro. Mater. Technol. 2016, 31, 23-27. [CrossRef]

392. Tesch, A.; Wenisch, C.; Herrmann, K.H.; Reichenbach, J.R.; Warncke, P.; Fischer, D.; Muller, F.A. Luminomagnetic $\mathrm{Eu}(3+)$ - and $\mathrm{Dy}(3+)$-doped hydroxyapatite for multimodal imaging. Mater. Sci. Eng. C Mater. Biol. Appl. 2017, 81, 422-431. [CrossRef] [PubMed]

393. Zheng, X.; Liu, M.; Hui, J.; Fan, D.; Ma, H.; Zhang, X.; Wang, Y.; Wei, Y. Ln $^{3+}$-doped hydroxyapatite nanocrystals: Controllable synthesis and cell imaging. Phys. Chem. Chem. Phys. 2015, 17, 20301-20307. [CrossRef] [PubMed]

394. Jiménez-Flores, Y.; Suárez-Quezada, M.; Rojas-Trigos, J.B.; Suárez, V.; Mantilla, A. Sol-gel synthesis of Tb-doped hydroxyapatite with high performance as photocatalyst for 2, 4 dichlorophenoxyacetic acid mineralization. J. Chem. Technol. Biotechnol. 2017, 92, 1521-1530. [CrossRef]

395. Lu, Y.H.; Xiao, X.F.; Zheng, X.; Wu, S.S.; Liu, R.F. Hydrothermal synthesis and characterization of $\mathrm{Tb}^{3+}$ doped hydroxyapatite. Adv. Mater. Res. 2011, 391-392, 709-713. [CrossRef]

396. Luque, P.; Cervantes, D.; Gomez-Gutierrez, C.; Carrillo-Castillo, A.; Mota-Gonzalez, M.; Vilchis-Nestor, A.; Olivas, A. Synthesis and characterization of terbium doped hydroxyapatite at different percentages by weight. Dig. J. Nanomater. Biostruct. 2017, 12, 135-139.

397. Yin, H.; Li, Y.; Bai, J.; Ma, M.; Liu, J. Effect of calcinations temperature on the luminescence intensity and fluorescent lifetime of $\mathrm{Tb}^{3+}$-doped hydroxyapatite (Tb-HA) nanocrystallines. J. Materiomics 2017, 3, 144-149. [CrossRef]

398. Sun, L.J.; Ni, P.F.; Guo, D.G.; Fang, C.Q.; Wang, J.; Yang, F.; Huang, X.F.; Hao, Y.Z.; Zhu, H.; Xu, K.W. Synthesis and characterization of Tb-incorporated apatite nano-scale powders. J. Mater. Sci. Technol. 2012, 28, 773-778. [CrossRef]

399. Wei, Y.; He, Y.; Li, X.; Chen, H.; Deng, X. Cellular uptake and delivery-dependent effects of Tb(3+)-doped hydroxyapatite nanorods. Molecules 2017, 22, 1043. [CrossRef] [PubMed]

400. Mondal, S.; Manivasagan, P.; Bharathiraja, S.; Santha Moorthy, M.; Kim, H.H.; Seo, H.; Lee, K.D.; Oh, J. Magnetic hydroxyapatite: A promising multifunctional platform for nanomedicine application. Int. J. Nanomed. 2017, 12, 8389-8410. [CrossRef] [PubMed]

401. Zarinfar, A.; Shafaei, M.; Ziaie, F. Synthesis, characterization and thermoluminescence properties of nanostructure gadolinium doped hydroxyapatite (HAP:Gd). Procedia Mater. Sci. 2015, 11, 293-298. [CrossRef]

402. Laranjeira, M.S.; Moco, A.; Ferreira, J.; Coimbra, S.; Costa, E.; Santos-Silva, A.; Ferreira, P.J.; Monteiro, F.J. Different hydroxyapatite magnetic nanoparticles for medical imaging: Its effects on hemostatic, hemolytic activity and cellular cytotoxicity. Colloid Surf. B Biointerfaces 2016, 146, 363-374. [CrossRef] [PubMed]

403. Sanchez Lafarga, A.K.; Pacheco Moises, F.P.; Gurinov, A.; Ortiz, G.G.; Carbajal Arizaga, G.G. Dual responsive dysprosium-doped hydroxyapatite particles and toxicity reduction after functionalization with folic and glucuronic acids. Mater. Sci. Eng. C Mater. Biol. Appl. 2015, 48, 541-547. [CrossRef] [PubMed]

404. Pham, V.-H.; Van, H.N.; Tam, P.D.; Ha, H.N.T. A novel 1540 nm light emission from erbium doped hydroxyapatite/ $\beta$-tricalcium phosphate through co-precipitation method. Mater. Lett. 2016, 167, 145-147. [CrossRef]

405. Yang, H.; Yang, G.; Wang, C.; Xu, K.W. Preparation and biocompatibility of nanoscaled La/Ag/HAP powder. Adv. Mater. Res. 2011, 308-310, 2173-2179. [CrossRef]

406. Lanone, S.; Rogerieux, F.; Geys, J.; Dupont, A.; Maillot-Marechal, E.; Boczkowski, J.; Lacroix, G.; Hoet, P. Comparative toxicity of 24 manufactured nanoparticles in human alveolar epithelial and macrophage cell lines. Part. Fibre Toxicol. 2009, 6, 14. [CrossRef] [PubMed]

407. Wataha, J.C.; Hanks, C.; Craig, R.G. In vitro effect of metal ions on cellular metabolism and the correlation between these effects and the uptake of the ions. J. Biomed. Mater. Res. 1994, 28, 427-433. [CrossRef] [PubMed] 
408. Wataha, J.C.; Hanks, C.T.; Sun, Z. Effect of cell line on in vitro metal ion cytotoxicity. Dent. Mater. 1994, 10, 156-161. [CrossRef]

409. Bhugra, C.; Pikal, M.J. Role of thermodynamic, molecular, and kinetic factors in crystallization from the amorphous state. J. Pharm. Sci. 2008, 97, 1329-1349. [CrossRef] [PubMed]

410. Karavelidis, V.; Karavas, E.; Giliopoulos, D.; Papadimitriou, S.; Bikiaris, D. Evaluating the effects of crystallinity in new biocompatible polyester nanocarriers on drug release behavior. Int. J. Nanomed. 2011, 6, 3021-3032. [CrossRef]

411. Hsiao, I.-L.; Huang, Y.-J. Effects of serum on cytotoxicity of nano-and micro-sized ZnO particles. J. Nanopart. Res. 2013, 15, 1829. [CrossRef] [PubMed]

412. Park, M.V.; Neigh, A.M.; Vermeulen, J.P.; de la Fonteyne, L.J.; Verharen, H.W.; Briedé, J.J.; van Loveren, H.; de Jong, W.H. The effect of particle size on the cytotoxicity, inflammation, developmental toxicity and genotoxicity of silver nanoparticles. Biomaterials 2011, 32, 9810-9817. [CrossRef] [PubMed]

413. Sohaebuddin, S.K.; Thevenot, P.T.; Baker, D.; Eaton, J.W.; Tang, L. Nanomaterial cytotoxicity is composition, size, and cell type dependent. Part. Fibre Toxicol. 2010, 7, 22. [CrossRef] [PubMed]

414. Yamamoto, A.; Honma, R.; Sumita, M.; Hanawa, T. Cytotoxicity evaluation of ceramic particles of different sizes and shapes. J. Biomed. Mater. Res. Part A 2004, 68, 244-256. [CrossRef] [PubMed]

415. Zapór, L. Effects of silver nanoparticles of different sizes on cytotoxicity and oxygen metabolism disorders in both reproductive and respiratory system cells. Arch. Environ. Prot. 2016, 42, 32-47. [CrossRef]

416. Champion, J.A.; Katare, Y.K.; Mitragotri, S. Particle shape: A new design parameter for micro-and nanoscale drug delivery carriers. J. Control. Release 2007, 121, 3-9. [CrossRef] [PubMed]

417. Gratton, S.E.; Ropp, P.A.; Pohlhaus, P.D.; Luft, J.C.; Madden, V.J.; Napier, M.E.; DeSimone, J.M. The effect of particle design on cellular internalization pathways. Proc. Natl. Acad. Sci. USA 2008, 105, 11613-11618. [CrossRef] [PubMed]

418. Xie, X.; Liao, J.; Shao, X.; Li, Q.; Lin, Y. The effect of shape on cellular uptake of gold nanoparticles in the forms of stars, rods, and triangles. Sci. Rep. 2017, 7, 3827. [CrossRef] [PubMed]

419. Zhao, X.; Ng, S.; Heng, B.C.; Guo, J.; Ma, L.; Tan, T.T.Y.; Ng, K.W.; Loo, S.C.J. Cytotoxicity of hydroxyapatite nanoparticles is shape and cell dependent. Arch. Toxicol. 2013, 87, 1037-1052. [CrossRef] [PubMed]

420. Biedermann, K.A.; Landolph, J.R. Role of valence state and solubility of chromium compounds on induction of cytotoxicity, mutagenesis, and anchorage independence in diploid human fibroblasts. Cancer Res. 1990, 50, 7835-7842. [PubMed]

421. Collins, B.J.; Stout, M.D.; Levine, K.E.; Kissling, G.E.; Melnick, R.L.; Fennell, T.R.; Walden, R.; Abdo, K.; Pritchard, J.B.; Fernando, R.A. Exposure to hexavalent chromium resulted in significantly higher tissue chromium burden compared with trivalent chromium following similar oral doses to male F344/N rats and female B6C3F1 mice. Toxicol. Sci. 2010, 118, 368-379. [CrossRef] [PubMed]

422. Dasari, T.S.; Zhang, Y.; Yu, H. Antibacterial activity and cytotoxicity of gold (I) and (III) ions and gold nanoparticles. Biochem. Pharmacol. 2015, 4, 199. [CrossRef] [PubMed]

423. Naganuma, T.; Traversa, E. The effect of cerium valence states at cerium oxide nanoparticle surfaces on cell proliferation. Biomaterials 2014, 35, 4441-4453. [CrossRef] [PubMed]

424. Xu, L.; Wu, C.; Lei, X.; Zhang, K.; Liu, C.; Ding, J.; Shi, X. Effect of oxidation time on cytocompatibility of ultrafine-grained pure Ti in micro-arc oxidation treatment. Surf. Coat. Technol. 2018, 342, 12-22. [CrossRef]

425. Zhang, W.; Yan, L.; Li, M.; Zhao, R.; Yang, X.; Ji, T.; Gu, Z.; Yin, J.-J.; Gao, X.; Nie, G. Deciphering the underlying mechanisms of oxidation-state dependent cytotoxicity of graphene oxide on mammalian cells. Toxicol. Lett. 2015, 237, 61-71. [CrossRef] [PubMed]

426. Namvar, F.; Rahman, H.S.; Mohamad, R.; Baharara, J.; Mahdavi, M.; Amini, E.; Chartrand, M.S.; Yeap, S.K. Cytotoxic effect of magnetic iron oxide nanoparticles synthesized via seaweed aqueous extract. Int. J. Nanomed. 2014, 9, 2479-2488. [CrossRef] [PubMed]

427. Tchounwou, P.B.; Yedjou, C.G.; Foxx, D.N.; Ishaque, A.B.; Shen, E. Lead-induced cytotoxicity and transcriptional activation of stress genes in human liver carcinoma (HepG2) cells. Mol. Cell. Biochem. 2004, 255, 161-170. [CrossRef] [PubMed]

428. Allagui, M.; Vincent, C.; Gaubin, Y.; Croute, F. Lithium toxicity and expression of stress-related genes or proteins in A549 cells. Biochim. Biophys. Acta Mol. Cell 2007, 1773, 1107-1115. [CrossRef] [PubMed]

429. Madiehe, A.M.; Mampuru, L.J.; Tyobeka, E.M. Induction of apoptosis in HL-60 cells by lithium. Biochem. Biophys. Res. Commun. 1995, 209, 768-774. [CrossRef] [PubMed] 
430. Repetto, G.; Del Peso, A.; Sanz, P.; Repetto, M. In vitro effects of lithium and nickel at different levels on Neuro-2a mouse Neuroblastoma cells. Toxicol. In Vitro 2001, 15, 363-368. [CrossRef]

431. Garland, E.; Parr, J.; Williamson, D.; Cohen, S. In vitro cytotoxicity of the sodium, potassium and calcium salts of saccharin, sodium ascorbate, sodium citrate and sodium chloride. Toxicol. In Vitro 1989, 3, 201-205. [CrossRef]

432. Hasan, M.S.; Werner-Zwanziger, U.; Boyd, D. Composition-structure-properties relationship of strontium borate glasses for medical applications. J. Biomed. Mater. Res. Part A 2015, 103, 2344-2354. [CrossRef] [PubMed]

433. Jeng, J.-H.; Hsieh, C.; Lan, W.; Chang, M.; Lin, S.; Hahn, L.; Kuo, M. Cytotoxicity of sodium fluoride on human oral mucosal fibroblasts and its mechanisms. Cell Biol. Toxicol. 1998, 14, 383-389. [CrossRef] [PubMed]

434. Slameňová, D.; Gabelova, A.; Ruppova, K. Cytotoxicity and genotoxicity testing of sodium fluoride on Chinese hamster V79 cells and human EUE cells. Mutat. Res. 1992, 279, 109-115. [CrossRef]

435. Gao, J.-C.; Qiao, L.-Y.; Xin, R.-L. Effect of $\mathrm{Mg}^{2+}$ concentration on biocompatibility of pure magnesium. Front. Mater. Sci. China 2010, 4, 126-131. [CrossRef]

436. Liu, X.; Xi, T.; Zheng, Y. Influence of the extraction parameters on the cytotoxicity test results of Mg materials. Prog. Nat. Sci. 2014, 24, 507-515. [CrossRef]

437. Mirmalek, S.; Jangholi, E.; Jafari, M.; Yadollah-Damavandi, S.; Javidi, M.; Parsa, Y.; Parsa, T.; Salimi-Tabatabaee, S.A.; Kolagar, H.G.; Jalil, S.K. Comparison of in vitro cytotoxicity and apoptogenic activity of magnesium chloride and cisplatin as conventional chemotherapeutic agents in the MCF-7 cell line. Asian Pac. J. Cancer Prev. 2016, 17, 131-134. [CrossRef] [PubMed]

438. Wong, H.M.; Yeung, K.W.; Lam, K.O.; Tam, V.; Chu, P.K.; Luk, K.D.; Cheung, K.M. A biodegradable polymer-based coating to control the performance of magnesium alloy orthopaedic implants. Biomaterials 2010, 31, 2084-2096. [CrossRef] [PubMed]

439. Aimaiti, A.; Maimaitiyiming, A.; Boyong, X.; Aji, K.; Li, C.; Cui, L. Low-dose strontium stimulates osteogenesis but high-dose doses cause apoptosis in human adipose-derived stem cells via regulation of the ERK1/2 signaling pathway. Stem Cell Res. Ther. 2017, 8, 282. [CrossRef] [PubMed]

440. Bonnelye, E.; Chabadel, A.; Saltel, F.; Jurdic, P. Dual effect of strontium ranelate: Stimulation of osteoblast differentiation and inhibition of osteoclast formation and resorption in vitro. Bone 2008, 42, 129-138. [CrossRef] [PubMed]

441. Er, K.; Polat, Z.A.; Özan, F.; Taşdemir, T.; Sezer, U.; Siso, Ş.H. Cytotoxicity analysis of strontium ranelate on cultured human periodontal ligament fibroblasts: A preliminary report. J. Formos. Med. Assoc. 2008, 107, 609-615. [CrossRef]

442. Hallab, N.J.; Anderson, S.; Caicedo, M.; Jacobs, J.J. Zirconium and niobium affect human osteoblasts, fibroblasts, and lymphocytes in a similar manner to more traditional implant alloy metals. J. ASTM Int. 2006, 3, 1-12. [CrossRef]

443. Puleo, D.A.; Huh, W.W. Acute toxicity of metal ions in cultures of osteogenic cells derived from bone marrow stromal cells. J. Appl. Biomater. 1995, 6, 109-116. [CrossRef] [PubMed]

444. Sun, Z.L.; Wataha, J.C.; Hanks, C.T. Effects of metal ions on osteoblast-like cell metabolism and differentiation. J. Biomed. Mater. Res. 1997, 34, 29-37. [CrossRef]

445. Milheiro, A.; Nozaki, K.; Kleverlaan, C.J.; Muris, J.; Miura, H.; Feilzer, A.J. In vitro cytotoxicity of metallic ions released from dental alloys. Odontology 2016, 104, 136-142. [CrossRef] [PubMed]

446. Damati, A.; Vlastos, D.; Philippopoulos, A.I.; Matthopoulos, D.P. Inorganic tin compounds do not induce micronuclei in human lymphocytes in the absence of metabolic activation. Drug Chem. Toxicol. 2014, 37, 213-220. [CrossRef] [PubMed]

447. Reynolds, A.S.; Pierre, T.H.; McCall, R.; Wu, J.; Gato, W.E. Evaluating the cytotoxicity of tin dioxide nanofibers. J. Environ. Sci. Health Part A Toxic/Hazard. Subst. Environ. Eng. 2018, 18, 1-6. [CrossRef] [PubMed]

448. Aydin, N.; Arslan, M.E.; Sonmez, E.S.; Turkez, H. Cytotoxicity analysis of tellurium dioxide nanoparticles on cultured human pulmonary alveolar epithelial and peripheral blood cell cultures. Biomed. Res. 2017, 28, 3300-3304.

449. Mahto, S.K.; Vinod, T.; Kim, J.-K.; Rhee, S.-W. Cytotoxic potentials of tellurium nanowires in BALB/3T3 fibroblast cells. Bull. Korean Chem. Soc. 2011, 32, 3405-3410. [CrossRef] 
450. Wen, H.; Zhong, J.; Shen, B.; Gan, T.; Fu, C.; Zhu, Z.; Li, R.; Yang, X. Comparative study of the cytotoxicity of the nanosized and microsized tellurium powders on HeLa cells. Front. Biol. 2013, 8, 444-450. [CrossRef]

451. Aykin-Burns, N.; Laegeler, A.; Kellogg, G.; Ercal, N. Oxidative effects of lead in young and adult Fisher 344 rats. Arch. Environ. Contam. Toxicol. 2003, 44, 417-420. [CrossRef] [PubMed]

452. Bruinink, A.; Reiser, P.; Müller, M.; Gähwiler, B.; Zbinden, G. Neurotoxic effects of bismuth in vitro. Toxicol. In Vitro 1992, 6, 285-293. [CrossRef]

453. Hernandez-Delgadillo, R.; Badireddy, A.R.; Zaragoza-Magaña, V.; Sánchez-Nájera, R.I.; Chellam, S.; Cabral-Romero, C. Effect of lipophilic bismuth nanoparticles on erythrocytes. J. Nanomater. 2015, 2015, 264024. [CrossRef]

454. Liman, R. Genotoxic effects of Bismuth(III) oxide nanoparticles by Allium and Comet assay. Chemosphere 2013, 93, 269-273. [CrossRef] [PubMed]

455. Luo, Y.; Wang, C.; Qiao, Y.; Hossain, M.; Ma, L.; Su, M. In vitro cytotoxicity of surface modified bismuth nanoparticles. J. Mater. Sci. Mater. Med. 2012, 23, 2563-2573. [CrossRef] [PubMed]

456. Apaza-Bedoya, K.; Bijukumar, D.; Benfatti, C.; Mathew, M.; da Silva, J.; Souza, J. Adverse local and systemic effect of nanoparticles released from oral and cranio-maxillofacial implants. In Nanostructured Biomaterials for Cranio-Maxillofacial and Oral Applications; Souza, J., Hotza, D., Henrique, B., Boccaccini, A., Eds.; Elsevier: Amsterdam, The Netherlands, 2018; pp. 63-79. ISBN 9-780-128-14621-7.

457. Khan, M.; Naqvi, A.H.; Ahmad, M. Comparative study of the cytotoxic and genotoxic potentials of zinc oxide and titanium dioxide nanoparticles. Toxicol. Rep. 2015, 2, 765-774. [CrossRef] [PubMed]

458. Bellusci, M.; La Barbera, A.; Padella, F.; Mancuso, M.; Pasquo, A.; Grollino, M.G.; Leter, G.; Nardi, E.; Cremisini, C.; Giardullo, P. Biodistribution and acute toxicity of a nanofluid containing manganese iron oxide nanoparticles produced by a mechanochemical process. Int. J. Nanomed. 2014, 9, 1919-1929. [CrossRef]

459. dos Santos, A.M.; Santos, D.; Au, C.; Milatovic, D.; Aschner, M.; Batoréu, M.C.C. Antioxidants prevent the cytotoxicity of manganese in RBE4 cells. Brain Res. 2008, 1236, 200-205. [CrossRef] [PubMed]

460. Hernroth, B.; Holm, I.; Gondikas, A.; Tassidis, H. Manganese inhibits viability of prostate cancer cells. Anticancer Res. 2018, 38, 137-145. [CrossRef] [PubMed]

461. Naqvi, S.; Samim, M.; Abdin, M.; Ahmed, F.J.; Maitra, A.; Prashant, C.; Dinda, A.K. Concentration-dependent toxicity of iron oxide nanoparticles mediated by increased oxidative stress. Int. J. Nanomed. 2010, 5, 983-989. [CrossRef] [PubMed]

462. Garza-Cervantes, J.A.; Chávez-Reyes, A.; Castillo, E.C.; García-Rivas, G.; Ortega-Rivera, O.A.; Salinas, E.; Ortiz-Martínez, M.; Gómez-Flores, S.L.; Peña-Martínez, J.A.; Pepi-Molina, A. Synergistic antimicrobial effects of silver/transition-metal combinatorial treatments. Sci. Rep. 2017, 7, 903. [CrossRef] [PubMed]

463. Kanaji, A.; Orhue, V.; Caicedo, M.S.; Virdi, A.S.; Sumner, D.R.; Hallab, N.J.; Yoshiaki, T.; Sena, K. Cytotoxic effects of cobalt and nickel ions on osteocytes in vitro. J. Orthop. Surg. Res. 2014, 9, 91. [CrossRef] [PubMed]

464. Ada, K.; Turk, M.; Oguztuzun, S.; Kilic, M.; Demirel, M.; Tandogan, N.; Ersayar, E.; Latif, O. Cytotoxicity and apoptotic effects of nickel oxide nanoparticles in cultured HeLa cells. Folia Histochem. Cytobiol. 2010, 48, 524-529. [CrossRef] [PubMed]

465. Ahamed, M. Toxic response of nickel nanoparticles in human lung epithelial A549 cells. Toxicol. In Vitro 2011, 25, 930-936. [CrossRef] [PubMed]

466. Anchordoquy, J.M.; Anchordoquy, J.P.; Nikoloff, N.; Pascua, A.M.; Furnus, C.C. High copper concentrations produce genotoxicity and cytotoxicity in bovine cumulus cells. Environ. Sci. Pollut. Res. 2017, 24, 20041-20049. [CrossRef] [PubMed]

467. Sahu, D.; Kannan, G.; Tailang, M.; Vijayaraghavan, R. In vitro cytotoxicity of nanoparticles: A comparison between particle size and cell type. J. Nanosci. 2016, 2016, 4023852. [CrossRef]

468. Andelman, T.; Gordonov, S.; Busto, G.; Moghe, P.V.; Riman, R.E. Synthesis and cytotoxicity of $\mathrm{Y}_{2} \mathrm{O}_{3}$ nanoparticles of various morphologies. Nanoscale Res. Lett. 2010, 5, 263. [CrossRef] [PubMed]

469. Lee, S.; Kasuga, T.; Kato, K. Effects of $\mathrm{Y}_{2} \mathrm{O}_{3}$ particle size on cytotoxicity and cell morphology. J. Ceram. Soc. Jpn. 2010, 118, 428-433. [CrossRef]

470. Selvaraj, V.; Bodapati, S.; Murray, E.; Rice, K.M.; Winston, N.; Shokuhfar, T.; Zhao, Y.; Blough, E. Cytotoxicity and genotoxicity caused by yttrium oxide nanoparticles in HEK293 cells. Int. J. Nanomed. 2014, 9, 1379-1391. [CrossRef] [PubMed]

471. Braydich-Stolle, L.; Hussain, S.; Schlager, J.J.; Hofmann, M.-C. In vitro cytotoxicity of nanoparticles in mammalian germline stem cells. Toxicol. Sci. 2005, 88, 412-419. [CrossRef] [PubMed] 
472. Siddiqui, M.A.; Saquib, Q.; Ahamed, M.; Farshori, N.N.; Ahmad, J.; Wahab, R.; Khan, S.T.; Alhadlaq, H.A.; Musarrat, J.; Al-Khedhairy, A.A. Molybdenum nanoparticles-induced cytotoxicity, oxidative stress, G2/M arrest, and DNA damage in mouse skin fibroblast cells (L929). Colloid Surf. B Biointerfaces 2015, 125, 73-81. [CrossRef] [PubMed]

473. Ostad, S.N.; Dehnad, S.; Nazari, Z.E.; Fini, S.T.; Mokhtari, N.; Shakibaie, M.; Shahverdi, A.R. Cytotoxic activities of silver nanoparticles and silver ions in parent and tamoxifen-resistant T47D human breast cancer cells and their combination effects with tamoxifen against resistant cells. Avicenna J. Med. Biotechnol. 2010, 2, 187. [PubMed]

474. Piao, M.J.; Kang, K.A.; Lee, I.K.; Kim, H.S.; Kim, S.; Choi, J.Y.; Choi, J.; Hyun, J.W. Silver nanoparticles induce oxidative cell damage in human liver cells through inhibition of reduced glutathione and induction of mitochondria-involved apoptosis. Toxicol. Lett. 2011, 201, 92-100. [CrossRef] [PubMed]

475. Składanowski, M.; Golinska, P.; Rudnicka, K.; Dahm, H.; Rai, M. Evaluation of cytotoxicity, immune compatibility and antibacterial activity of biogenic silver nanoparticles. Med. Microbiol. Immunol. 2016, 205, 603-613. [CrossRef] [PubMed]

476. Souza, T.A.; Franchi, L.P.; Rosa, L.R.; da Veiga, M.A.; Takahashi, C.S. Cytotoxicity and genotoxicity of silver nanoparticles of different sizes in CHO-K1 and CHO-XRS5 cell lines. Mutat. Res. Genet. Toxicol. Environ. Mutagen. 2016, 795, 70-83. [CrossRef] [PubMed]

477. Gao, J.; Li, R.; Wang, F.; Liu, X.; Zhang, J.; Hu, L.; Shi, J.; He, B.; Zhou, Q.; Song, M. Determining the cytotoxicity of rare earth element nanoparticles in macrophages and the involvement of membrane damage. Environ. Sci. Technol. 2017, 51, 13938-13948. [CrossRef] [PubMed]

478. Kostova, I.; Momekov, G.; Tzanova, T.; Karaivanova, M. Synthesis, characterization, and cytotoxic activity of new lanthanum(III) complexes of bis-coumarins. Bioinorg. Chem. Appl. 2006, 2006, 25651. [CrossRef] [PubMed]

479. Lim, C.-H. Toxicity of two different sized lanthanum oxides in cultured cells and Sprague-Dawley rats. Toxicol. Res. 2015, 31, 181-189. [CrossRef] [PubMed]

480. Jenkins, W.; Perone, P.; Walker, K.; Bhagavathula, N.; Aslam, M.N.; DaSilva, M.; Dame, M.K.; Varani, J. Fibroblast response to lanthanoid metal ion stimulation: Potential contribution to fibrotic tissue injury. Biol. Trace Elem. Res. 2011, 144, 621-635. [CrossRef] [PubMed]

481. Khan, S.; Ansari, A.A.; Rolfo, C.; Coelho, A.; Abdulla, M.; Al-Khayal, K.; Ahmad, R. Evaluation of in vitro cytotoxicity, biocompatibility, and changes in the expression of apoptosis regulatory proteins induced by cerium oxide nanocrystals. Sci. Technol. Adv. Mater. 2017, 18, 364-373. [CrossRef] [PubMed]

482. Lin, W.; Huang, Y.-W.; Zhou, X.-D.; Ma, Y. Toxicity of cerium oxide nanoparticles in human lung cancer cells. Int. J. Toxicol. 2006, 25, 451-457. [CrossRef] [PubMed]

483. Andiappan, K.; Sanmugam, A.; Deivanayagam, E.; Karuppasamy, K.; Kim, H.-S.; Vikraman, D. In vitro cytotoxicity activity of novel Schiff base ligand-lanthanide complexes. Sci. Rep. 2018, 8, 3054. [CrossRef] [PubMed]

484. Kostova, I.; Momekov, G. Synthesis, characterization and cytotoxicity evaluation of new cerium(III), lanthanum(III) and neodymium(III) complexes. Appl. Organomet. Chem. 2007, 21, 226-233. [CrossRef]

485. Harper, S.; Usenko, C.; Tanguay, R. Differential distribution and toxicity of nanomaterials in vivo. In Proceedings of the 2006 AIChE Annual Meeting, San Francisco, CA, USA, 12-17 November 2006; pp. 12-17.

486. Cho, S.; Lee, Y.; Lee, S.; Choi, Y.J.; Chung, H.W. Enhanced cytotoxic and genotoxic effects of gadolinium following ELF-EMF irradiation in human lymphocytes. Drug Chem. Toxicol. 2014, 37, 440-447. [CrossRef] [PubMed]

487. Heinrich, M.C.; Kuhlmann, M.K.; Kohlbacher, S.; Scheer, M.; Grgic, A.; Heckmann, M.B.; Uder, M. Cytotoxicity of iodinated and gadolinium-based contrast agents in renal tubular cells at angiographic concentrations: In vitro study. Radiology 2007, 242, 425-434. [CrossRef] [PubMed]

488. Paltoo, D. Effects of terbium on the cytotoxicity of cisplatin in FaDu human head and neck squamous cell carcinoma. Cancer Biochem. Biophys. 1998, 16, 213-227. [PubMed]

489. Atabaev, T.S.; Shin, Y.C.; Song, S.-J.; Han, D.-W.; Hong, N.H. Toxicity and T2-weighted magnetic resonance imaging potentials of holmium oxide nanoparticles. Nanomaterials 2017, 7, 216. [CrossRef] [PubMed] 
490. Carmona, A.; Malard, V.; Avazeri, E.; Roudeau, S.; Porcaro, F.; Paredes, E.; Vidaud, C.; Bresson, C.; Ortega, R. Uranium exposure of human dopaminergic cells results in low cytotoxicity, accumulation within sub-cytoplasmic regions, and down regulation of MAO-B. Neurotoxicology 2018, 68, 177-188. [CrossRef] [PubMed]

491. Thiébault, C.; Carriere, M.; Milgram, S.; Simon, A.; Avoscan, L.; Gouget, B. Uranium induces apoptosis and is genotoxic to normal rat kidney (NRK-52E) proximal cells. Toxicol. Sci. 2007, 98, 479-487. [CrossRef] [PubMed]

492. Popa, A.C.; Stan, G.E.; Husanu, M.A.; Mercioniu, I.; Santos, L.; Fernandes, H.R.; Ferreira, J.M.F. Bioglass implant-coating interactions in synthetic physiological fluids with varying degrees of biomimicry. Int. J. Nanomed. 2017, 12, 683-707. [CrossRef] [PubMed]

493. Miyazaki, T.; Sueoka, M.; Shirosaki, Y.; Shinozaki, N.; Shiraishi, T. Development of hafnium metal and titanium-hafnium alloys having apatite-forming ability by chemical surface modification. J. Biomed. Mater. Res. Part B 2017. [CrossRef] [PubMed]

494. Renke-Gluszko, M.; El Fray, M. The effect of simulated body fluid on the mechanical properties of multiblock poly (aliphatic/aromatic-ester) copolymers. Biomaterials 2004, 25, 5191-5198. [CrossRef] [PubMed]

495. Thaveedeetrakul, A.; Witit-anun, N.; Boonamnuayvitaya, V. The role of target-to-substrate distance on the DC magnetron sputtered zirconia thin films' bioactivity. Appl. Surf. Sci. 2012, 258, 2612-2619. [CrossRef]

496. Bohner, M.; Lemaitre, J. Can bioactivity be tested in vitro with SBF solution? Biomaterials 2009, 30, $2175-2179$. [CrossRef] [PubMed]

497. Lee, J.T.; Leng, Y.; Chow, K.L.; Ren, F.; Ge, X.; Wang, K.; Lu, X. Cell culture medium as an alternative to conventional simulated body fluid. Acta Biomater. 2011, 7, 2615-2622. [CrossRef] [PubMed]

498. Liu, P.; Tao, J.; Cai, Y.; Pan, H.; Xu, X.; Tang, R. Role of fetal bovine serum in the prevention of calcification in biological fluids. J. Cryst. Growth 2008, 310, 4672-4675. [CrossRef]

499. Mahmood, T.; Davies, J. Incorporation of amino acids within the surface reactive layers of bioactive glass in vitro: An XPS study. J. Mater. Sci. Mater. Med. 2000, 11, 19-23. [CrossRef] [PubMed]

500. Tas, A. The use of physiological solutions or media in calcium phosphate synthesis and processing. Acta Biomater. 2014, 10, 1771-1792. [CrossRef] [PubMed]

501. Popa, A.C.; Stan, G.E.; Besleaga, C.; Ion, L.; Maraloiu, V.A.; Tulyaganov, D.U.; Ferreira, J.M.F. Submicrometer hollow bioglass cones deposited by radio frequency magnetron sputtering: Formation mechanism, properties, and prospective biomedical applications. ACS Appl. Mater. Interfaces 2016, 8, 4357-4367. [CrossRef] [PubMed]

502. Almubarak, S.; Nethercott, H.; Freeberg, M.; Beaudon, C.; Jha, A.; Jackson, W.; Marcucio, R.; Miclau, T.; Healy, K.; Bahney, C. Tissue engineering strategies for promoting vascularized bone regeneration. Bone 2016, 83, 197-209. [CrossRef] [PubMed]

503. Kowalczewski, C.J.; Saul, J.M. Biomaterials for the delivery of growth factors and other therapeutic agents in tissue engineering approaches to bone regeneration. Front. Pharmacol. 2018, 9, 513. [CrossRef] [PubMed]

504. Nandi, S.K.; Kundu, B.; Mukherjee, J.; Mahato, A.; Datta, S.; Balla, V.K. Converted marine coral hydroxyapatite implants with growth factors: In vivo bone regeneration. Mater. Sci. Eng. C Mater. Biol. Appl. 2015, 49, 816-823. [CrossRef] [PubMed]

505. Kalajzic, I.; Staal, A.; Yang, W.-P.; Wu, Y.; Johnson, S.E.; Feyen, J.H.; Krueger, W.; Maye, P.; Yu, F.; Zhao, Y.; et al. Expression profile of osteoblast lineage at defined stages of diferentiation. J. Biol. Chem. 2005, 280, 24618-24626. [CrossRef] [PubMed]

506. Klontzas, M.E.; Vernardis, S.I.; Heliotis, M.; Tsiridis, E.; Mantalaris, A. Metabolomics analysis of the osteogenic differentiation of umbilical cord blood mesenchymal stem cells reveals differential sensitivity to osteogenic agents. Stem Cells Dev. 2017, 26, 723-733. [CrossRef] [PubMed]

507. Kim, H.K.; Lee, S.G.; Lee, S.W.; Oh, B.J.; Kim, J.H.; Kim, J.A.; Lee, G.; Jang, J.D.; Joe, Y.A. A subset of paracrine factors as efficient biomarkers for predicting vascular regenerative efficacy of mesenchymal stromal/stem cells. Stem Cells 2018, in press. [CrossRef] [PubMed]

508. Pelosi, E.; Castelli, G.; Testa, U. Endothelial progenitors. Blood Cells Mol. Dis. 2014, 52, 186-194. [CrossRef] [PubMed]

509. Du, B.; Liu, W.; Deng, Y.; Li, S.; Liu, X.; Gao, Y.; Zhou, L. Angiogenesis and bone regeneration of porous nano-hydroxyapatite/coralline blocks coated with rhVEGF165 in critical-size alveolar bone defects in vivo. Int. J. Nanomed. 2015, 10, 2555-2565. [CrossRef] 
510. Bose, S.; Fielding, G.; Tarafder, S.; Bandyopadhyay, A. Understanding of dopant-induced osteogenesis and angiogenesis in calcium phosphate ceramics. Trends Biotechnol. 2013, 31, 594-605. [CrossRef] [PubMed]

511. Kulanthaivel, S.; Mishra, U.; Agarwal, T.; Giri, S.; Pal, K.; Pramanik, K.; Banerjee, I. Improving the osteogenic and angiogenic properties of synthetic hydroxyapatite by dual doping of bivalent cobalt and magnesium ion. Ceram. Int. 2015, 41, 11323-11333. [CrossRef]

512. Birgani, Z.T.; Fennema, E.; Gijbels, M.J.; de Boer, J.; van Blitterswijk, C.A.; Habibovic, P. Stimulatory effect of cobalt ions incorporated into calcium phosphate coatings on neovascularization in an in vivo intramuscular model in goats. Acta Biomater. 2016, 36, 267-276. [CrossRef] [PubMed]

513. Calabrese, G.; Giuffrida, R.; Forte, S.; Salvatorelli, L.; Fabbi, C.; Figallo, E.; Gulisano, M.; Parenti, R.; Magro, G.; Colarossi, C. Bone augmentation after ectopic implantation of a cell-free collagen-hydroxyapatite scaffold in the mouse. Sci. Rep. 2016, 6, 36399. [CrossRef] [PubMed]

514. Deng, L.; Li, D.; Yang, Z.; Xie, X.; Kang, P. Repair of the calvarial defect in goat model using magnesium-doped porous hydroxyapatite combined with recombinant human bone morphogenetic protein-2. Bio-Med. Mater. Eng. 2017, 28, 361-377. [CrossRef] [PubMed]

515. Ehret, C.; Aid-Launais, R.; Sagardoy, T.; Siadous, R.; Bareille, R.; Rey, S.; Pechev, S.; Etienne, L.; Kalisky, J.; De Mones, E. Strontium-doped hydroxyapatite polysaccharide materials effect on ectopic bone formation. PLoS ONE 2017, 12, e0184663. [CrossRef] [PubMed]

516. Li, D.; Xie, X.; Yang, Z.; Wang, C.; Wei, Z.; Kang, P. Enhanced bone defect repairing effects in glucocorticoid-induced osteonecrosis of the femoral head using a porous nano-lithium-hydroxyapatite/ gelatin microsphere/erythropoietin composite scaffold. Biomater. Sci. 2018, 6, 519-537. [CrossRef] [PubMed]

517. Madden, L.R.; Mortisen, D.J.; Sussman, E.M.; Dupras, S.K.; Fugate, J.A.; Cuy, J.L.; Hauch, K.D.; Laflamme, M.A.; Murry, C.E.; Ratner, B.D. Proangiogenic scaffolds as functional templates for cardiac tissue engineering. Proc. Natl. Acad. Sci. USA 2010, 107, 15211-15216. [CrossRef] [PubMed]

518. Oliviero, O.; Ventre, M.; Netti, P. Functional porous hydrogels to study angiogenesis under the effect of controlled release of vascular endothelial growth factor. Acta Biomater. 2012, 8, 3294-3301. [CrossRef] [PubMed]

519. Xiao, X.; Wang, W.; Liu, D.; Zhang, H.; Gao, P.; Geng, L.; Yuan, Y.; Lu, J.; Wang, Z. The promotion of angiogenesis induced by three-dimensional porous beta-tricalcium phosphate scaffold with different interconnection sizes via activation of Pi3K/Akt pathways. Sci. Rep. 2015, 5, 9409. [CrossRef] [PubMed]

520. Artel, A.; Mehdizadeh, H.; Chiu, Y.-C.; Brey, E.M.; Cinar, A. An agent-based model for the investigation of neovascularization within porous scaffolds. Tissue Eng. A 2011, 17, 2133-2141. [CrossRef] [PubMed]

521. Kuboki, Y.; Jin, Q.; Takita, H. Geometry of carriers controlling phenotypic expression in bmp-induced osteogenesis and chondrogenesis. J. Bone Jt. Surg. Am. Vol. 2001, 83, S1-S105. [CrossRef]

522. Wang, Z.; Chang, J.; Bai, F.; Sun, X.; Lu, J.; Lin, L.; Chen, L.; Rong, D. Role of the porous structure of the bioceramic scaffolds in bone tissue engineering. Nat. Preced. 2010. Available online: http://precedings. nature.com/documents/4148/version/1 (accessed on 12 October 2018).

523. Shanmugam, S.; Gopal, B. Antimicrobial and cytotoxicity evaluation of aliovalent substituted hydroxyapatite. Appl. Surf. Sci. 2014, 303, 277-281. [CrossRef]

524. Turkoz, M.; Atilla, A.O.; Evis, Z. Silver and fluoride doped hydroxyapatites: Investigation by microstructure, mechanical and antibacterial properties. Ceram. Int. 2013, 39, 8925-8931. [CrossRef]

525. Gopi, D.; Shinyjoy, E.; Kavitha, L. Synthesis and spectral characterization of silver/magnesium co-substituted hydroxyapatite for biomedical applications. Spectrochim. Acta Part A Mol. Biomol. Spectrosc. 2014, 127, 286-291. [CrossRef] [PubMed]

526. Mansour, S.; El-Dek, S.; Dorozhkin, S.; Ahmed, M. Physico-mechanical properties of Mg and Ag doped hydroxyapatite/chitosan biocomposites. New J. Chem. 2017, 41, 13773-13783. [CrossRef]

527. Huang, Y.; Xu, Z.; Zhang, X.; Chang, X.; Zhang, X.; Li, Y.; Ye, T.; Han, R.; Han, S.; Gao, Y. Nanotube-formed Ti substrates coated with silicate/silver co-doped hydroxyapatite as prospective materials for bone implants. J. Alloys Compd. 2017, 697, 182-199. [CrossRef]

528. Geng, Z.; Cui, Z.; Li, Z.; Zhu, S.; Liang, Y.; Liu, Y.; Li, X.; He, X.; Yu, X.; Wang, R. Strontium incorporation to optimize the antibacterial and biological characteristics of silver-substituted hydroxyapatite coating. Mater. Sci. Eng. C Mater. Biol. Appl. 2016, 58, 467-477. [CrossRef] [PubMed] 
529. Geng, Z.; Wang, R.; Zhuo, X.; Li, Z.; Huang, Y.; Ma, L.; Cui, Z.; Zhu, S.; Liang, Y.; Liu, Y. Incorporation of silver and strontium in hydroxyapatite coating on titanium surface for enhanced antibacterial and biological properties. Mater. Sci. Eng. C Mater. Biol. Appl. 2017, 71, 852-861. [CrossRef] [PubMed]

530. Iqbal, N.; Kadir, M.R.A.; Mahmood, N.H.; Salim, N.; Froemming, G.R.; Balaji, H.; Kamarul, T. Characterization, antibacterial and in vitro compatibility of zinc-silver doped hydroxyapatite nanoparticles prepared through microwave synthesis. Ceram. Int. 2014, 40, 4507-4513. [CrossRef]

531. Gopi, D.; Sathishkumar, S.; Karthika, A.; Kavitha, L. Development of $\mathrm{Ce}^{3+} / \mathrm{Eu}^{3+}$ dual-substituted hydroxyapatite coating on surgical grade stainless steel for improved antimicrobial and bioactive properties. Ind. Eng. Chem. Res. 2014, 53, 20145-20153. [CrossRef]

532. Gopi, D.; Ramya, S.; Rajeswari, D.; Karthikeyan, P.; Kavitha, L. Strontium, cerium co-substituted hydroxyapatite nanoparticles: Synthesis, characterization, antibacterial activity towards prokaryotic strains and in vitro studies. Colloid Surf. A Physicochem. Eng. Asp. 2014, 451, 172-180. [CrossRef]

533. Huang, Y.; Hao, M.; Nian, X.; Qiao, H.; Zhang, X.; Zhang, X.; Song, G.; Guo, J.; Pang, X.; Zhang, H. Strontium and copper co-substituted hydroxyapatite-based coatings with improved antibacterial activity and cytocompatibility fabricated by electrodeposition. Ceram. Int. 2016, 42, 11876-11888. [CrossRef]

534. Lowry, N.; Brolly, M.; Han, Y.; McKillop, S.; Meenan, B.; Boyd, A. Synthesis and characterisation of nanophase hydroxyapatite co-substituted with strontium and zinc. Ceram. Int. 2018, 44, 7761-7770. [CrossRef]

535. Lowry, N.; Han, Y.; Meenan, B.; Boyd, A. Strontium and zinc co-substituted nanophase hydroxyapatite. Ceram. Int. 2017, 43, 12070-12078. [CrossRef]

536. Huang, Y.; Zhang, X.; Mao, H.; Li, T.; Zhao, R.; Yan, Y.; Pang, X. Osteoblastic cell responses and antibacterial efficacy of $\mathrm{Cu} / \mathrm{Zn}$ co-substituted hydroxyapatite coatings on pure titanium using electrodeposition method. RSC Adv. 2015, 5, 17076-17086. [CrossRef]

537. Ramya, J.R.; Arul, K.T.; Elayaraja, K.; Kalkura, S.N. Physicochemical and biological properties of iron and zinc ions co-doped nanocrystalline hydroxyapatite, synthesized by ultrasonication. Ceram. Int. 2014, 40, 16707-16717. [CrossRef]

538. Karthika, A. Aliovalent ions substituted hydroxyapatite coating on titanium for improved medical applications. Mater. Today Proc. 2018, 5, 8768-8774. [CrossRef]

539. Sridevi, C.; Sathishkumar, S.; Elavarasan, S.; Rajavel, R.; Maheswaran, P. Investigation of anticorrosion, antibacterial and in vitro biological performance of terbium/gadolinium dual substituted hydroxyapatite coating on surgical grade stainless steel for biomedical applications. Chem. Sci. Trans. 2018, 7, 319-328. [CrossRef]

540. Sanyal, V.; Raja, C.R. Structural and antibacterial activity of hydroxyapatite and fluorohydroxyapatite co-substituted with zirconium-cerium ions. Appl. Phys. A Mater. Sci. Process. 2016, 122, 132. [CrossRef]

541. Sandhyarani, M.; Rameshbabu, N.; Venkateswarlu, K.; Ravisankar, K.; Ashok, M.; Anandan, S. Photocatalytic and antibacterial activity of titanium, fluorine and silver co-substituted hydroxyapatite. Int. J. Mod. Phys. Conf. Ser. 2013, 22, 268-277. [CrossRef]

542. Rajendran, A.; Balakrishnan, S.; Kulandaivelu, R.; Nellaiappan, S.N.T. Multi-element substituted hydroxyapatites: Synthesis, structural characteristics and evaluation of their bioactivity, cell viability, and antibacterial activity. J. Sol-Gel Sci. Technol. 2018, 86, 441-458. [CrossRef]

543. Zhou, J.; Zhao, L. Multifunction Sr, Co and F co-doped microporous coating on titanium of antibacterial, angiogenic and osteogenic activities. Sci. Rep. 2016, 6, 29069. [CrossRef] [PubMed]

544. Bir, F.; Khireddine, H.; Touati, A.; Sidane, D.; Yala, S.; Oudadesse, H. Electrochemical depositions of fluorohydroxyapatite doped by $\mathrm{Cu}^{2+}, \mathrm{Zn}^{2+}, \mathrm{Ag}^{+}$on stainless steel substrates. Appl. Surf. Sci. 2012, 258, 7021-7030. [CrossRef]

545. Hu, C.; Guo, J.; Qu, J.; Hu, X. Efficient destruction of bacteria with Ti(IV) and antibacterial ions in co-substituted hydroxyapatite films. Appl. Catal. B Environ. 2007, 73, 345-353. [CrossRef]

546. Quarto, R.; Mastrogiacomo, M.; Cancedda, R.; Kutepov, S.M.; Mukhachev, V.; Lavroukov, A.; Kon, E.; Marcacci, M. Repair of large bone defects with the use of autologous bone marrow stromal cells. N. Engl. J. Med. 2001, 344, 385-386. [CrossRef] [PubMed]

547. Marcacci, M.; Kon, E.; Moukhachev, V.; Lavroukov, A.; Kutepov, S.; Quarto, R.; Mastrogiacomo, M.; Cancedda, R. Stem cells associated with macroporous bioceramics for long bone repair: 6-to 7-year outcome of a pilot clinical study. Tissue Eng. 2007, 13, 947-955. [CrossRef] [PubMed] 
548. Bhargava, R.; Sankhla, S.; Gupta, A.; Changani, R.; Gagal, K. Percutaneous autologus bone marrow injection in the treatment of delayed or nonunion. Indian J. Orthop. 2007, 41, 67-71. [CrossRef] [PubMed]

549. Goel, A.; Sangwan, S.; Siwach, R.; Ali, A.M. Percutaneous bone marrow grafting for the treatment of tibial non-union. Injury 2005, 36, 203-206. [CrossRef] [PubMed]

550. Hernigou, P.; Poignard, A.; Beaujean, F.; Rouard, H. Percutaneous autologous bone-marrow grafting for nonunions: Influence of the number and concentration of progenitor cells. J. Bone Jt. Surg. Am. Vol. 2005, 87, 1430-1437. [CrossRef]

551. Kettunen, J.; Mäkelä, E.A.; Turunen, V.; Suomalainen, O.; Partanen, K. Percutaneous bone grafting in the treatment of the delayed union and non-union of tibial fractures. Injury 2002, 33, 239-245. [CrossRef]

2018 by the authors. Licensee MDPI, Basel, Switzerland. This article is an open access article distributed under the terms and conditions of the Creative Commons Attribution (CC BY) license (http://creativecommons.org/licenses/by/4.0/). 